Rapporter från Åldrande och Social Förändring No. 6

\title{
Exclusion and Inequality in Late Working Life: National Country Context: Sweden
}

EIWO Working Paper No. 5

Indre Genelyte', Annika Hever' $\&$ Andreas Motel-Klingebiel'

'Linköping University, Sweden

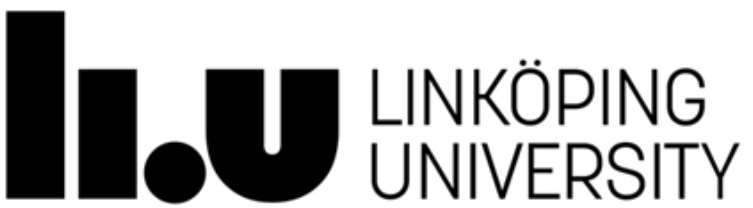




\section{EIWO \\ Exclusion and Inequality \\ in Late Working Life}

Rapporter från Åldrande och Social Förändring No. 6

Exclusion and Inequality in Late Working Life: National Country Context: Sweden

Indre Genelyte, Annika Heuer \& Andreas Motel-Klingebiel

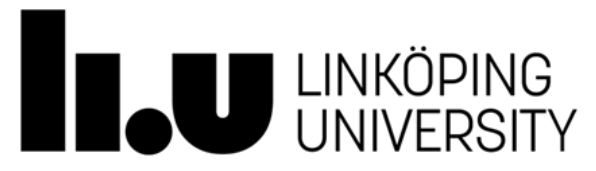

Department of Culture and Society

Division of Ageing and Social Change

Linköpings University, SE-581 83 Linköping, Sweden

Linköping 2021 
EXCLUSION AND INEQUALITY IN LATE WORKING LIFE

WORKING PAPER 5:

EXCLUSION AND INEQUALITY IN LATE WORKING LIFE: NATIONAL COUNTRY

CONTEXT - SWEDEN

(C) Indre Genelyte, Annika Heuer \& Andreas Motel-Klingebiel, 2021

(c) (i) This work is licensed under the Creative Commons Attribution 4.0

International License. To view a copy of this license, visit

http://creativecommons.org/licenses/by/4.0/.

Publisher: Linköping University Electronic Press 2021

ISBN 978-91-7929-190-7 (PDF)

https://doi.org/10.3384/9789179291907

ISSN 2004-2655 


\section{Contents}

Introduction

1 Late working life: historical and current policy context ...................................5

1.1 The sociodemographic profile and labour market participation patterns in late working life

1.2 Mapping the political-economic policy discourses: framing the late and extended working life

2 Late and extended working life: the Swedish social model, labour market actors

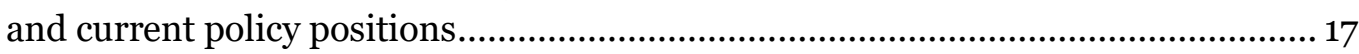

2.1 The Swedish social model and main labour market actors ........................ 17

2.2 Labour market actors and current policy positions.................................18

2.2.1 Gendered labour market inequalities and poverty: pay gap, care gap and pensions gap

2.2.2 Labour conditions: adjusted working tasks, sustainable working

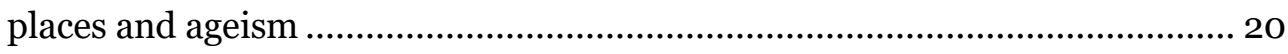

2.2.3 Skills miss-match and labour force shortages................................... 21

2.2.4 Possibility and a need for life-long learning........................................22

2.2.5 Swedish social model and the challenges of EU common market .........23

2.2.6 Employment security and flexibility ...........................................24

3 Late working life: patterns, characteristics, and inequalities ...........................25

3.1 Labour market participation..................................................................26

3.1.1 Health and life expectancy are increasing faster than labour market participation rates.......................................................................................26

3.1.2 Labour market participation patterns and characteristics: age and gender aspects.................................................................................. 30

3.1.3 Labour market participation patterns and characteristics: types of employment, sectors and working conditions ..................................................32

3.2 Education and lifelong learning..............................................................39

3.3 Labour market exit: patterns and characteristics .......................................42

4 The most influential policies regarding late working life profile ...................... 49

4.1 Retirement and pensions ................................................................... 49

4.2 Health insurance: sickness, rehabilitation and disability insurance ..........51 
EXCLUSION AND INEQUALITY IN LATE WORKING LIFE

WORKING PAPER 5:

EXCLUSION AND INEQUALITY IN LATE WORKING LIFE: NATIONAL COUNTRY

CONTEXT - SWEDEN

4.2.1 Disability benefit: activity and sickness compensations ........................52

4.2.2 Attendance allowance …....................................................................53

$4.3 \quad$ Labour market inclusion.....................................................................5

4.3.1 Active labour market policies................................................................54

4.3.2 Employment protection .................................................................5

4.3.3 Ageism and age discrimination .....................................................56

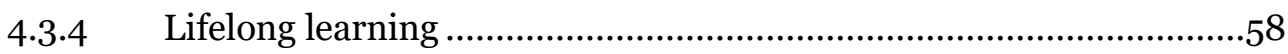

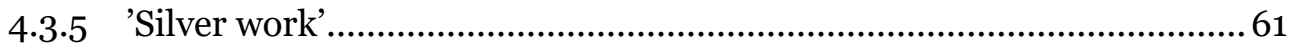

4.3.6 HR strategies and age-sensitive leadership .....................................62

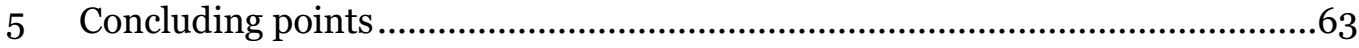

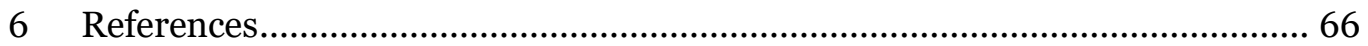

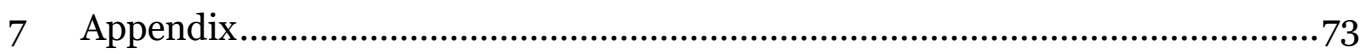

The research programme EIWO is funded by the Swedish Research Council for Health, Working Life and Welfare, grant no. 2019-01245. More information on the research programme and the programme consortium can be found at http://www.eiwoproject.org/.

EIWO Working Papers can be downloaded from the programme's website at http://www.eiwoproject.org/publications.html 


\section{Introduction}

This text is a first full draft that includes all the planned sections and covers key aspects of late working life issues in Sweden.

Chapter 1 presents key statistical data for population structure and demographic processes in Sweden as well as labour market participation among the older groups of the population. It is mapping the main political economic discourses that frame late working life and brings in some historically important points for understanding the developments in the Swedish discourse. The aspects of the welfare regime and its transformations after the 1990 s are included.

Chapter 2 briefly introduces the Swedish social model and discusses the roles of social partners and institutional context. It also informs about particularities regarding authorities and unique aspects of the Swedish social model. The most information-rich part is the presentation of the discourses and the positions of the main actors in the Swedish labour market. They actively contribute to shaping the political agenda and policy outcomes that translate into specific legislation.

Chapter 3 presents patterns and characteristics of current late working life in Sweden, and focusses on late labour market participation and exit, working conditions, sectoral distributions, and lifelong learning aspects. The main inequalities are discussed under these headings.

Chapter 4 is an account of the most influential policies for late working life in Sweden. It covers three main sections. Namely, retirement and pensions, disability insurance and policies related to the labour market inclusion. These policies are analysed regarding their impact on extending working lives as well as their potential to decrease inequalities in the labour market, in particular amongst older workers.

The text provides, finally, a brief overview of developments and policies regarding late working life in Sweden. Moreover, it sketches how these developments and policies affect inequalities in late working life. This is followed by an appendix containing additional data. 


\section{Late working life: historical and current policy context}

\subsection{The sociodemographic profile and labour market participation patterns in late working life}

Before introducing the policy context of late working life, it is important to first look into the demographic changes and patterns of labour market participation. It will give an overview of the longer-term developments and introduce the ageing, labour market and the debate on welfare state.

Sweden has been facing issues regarding their ageing society for a few decades now (Bengtsson \& Scott, 2011). As it is summarized in Table 1, population ageing in Sweden is mostly driven by shifts in mortality patterns with increases in average life expectancy and an extension of the life span. The average life expectancy is predicted to keep on increasing and by 2070 average life expectancy will be 89 years for women and 87 years for men. However, the trend is unequal based for instance on education level and income - higher education and income tends to mean longer average life expectancy (SCB, 2018a). Death rate and infant mortality rates have been decreasing while life expectancy has been increasing in recent years. The total population of the age group $65^{+}$has been rising for many decades now and made up $20 \%$ of the total population in 2019 (Table 1). The highest expected growth is forecasted for the population group $75^{+}$. In comparison to 2017, this group will increase by $43 \%$ in $2030,81 \%$ by 2050 and $116 \%$ by 2070 (SOU, 2020:69). Fertility has been slightly declining during the last five years period and is now around 1.7 (Table 1). Combined with high immigration this leads to continuous increases in population size in Sweden, where the latter two demographic factors slow the ageing trends down (Lundberg, 2020). 
EXCLUSION AND INEQUALITY IN LATE WORKING LIFE: NATIONAL COUNTRY CONTEXT - SWEDEN

Table 1: Population and population changes

Summary of Population Statistics

\begin{tabular}{|c|c|c|c|c|c|}
\hline Year & 2000 & 2005 & 2010 & 2015 & 2020 \\
\hline Population on 31 December & 8882792 & 9047752 & 9415570 & 9851017 & 10379295 \\
\hline Men \% & 49.5 & 49.6 & 49.8 & 50.1 & 50.3 \\
\hline Women \% & 50.5 & 50.4 & 50.2 & 49.9 & 49.7 \\
\hline Persons aged o-17 years \% & 21.8 & 21.4 & 20.4 & 20.6 & 21.1 \\
\hline Persons aged 65 years and above \% & 17.2 & $17 \cdot 3$ & 18.5 & 19.8 & 20.1 \\
\hline Foreign-born \% & 11.3 & 12.4 & 14.7 & 17.0 & 19.7 \\
\hline Births & 90441 & 101346 & 115641 & 114870 & 113077 \\
\hline Crude birth rate (per 10oo) & 10.2 & 11.2 & 12.3 & 11.7 & 10.9 \\
\hline Total fertility rate & 1.5 & 1.8 & 2.0 & 1.8 & 1.7 \\
\hline Deaths & 93461 & 91710 & 90487 & 90907 & 98124 \\
\hline Crude death rate (per 100o) & 10.5 & 10.2 & 9.6 & 9.3 & 9.5 \\
\hline Life expectancy, men & 77.4 & 78.4 & 79.5 & 80.3 & 80.6 \\
\hline Life expectancy, women & 82.0 & 82.8 & 83.5 & 84.0 & 84.3 \\
\hline Infant mortality rate (per 10oo) & 3.4 & 2.4 & 2.5 & 2.4 & 2.4 \\
\hline In-migration & 58659 & 65229 & 98801 & 134240 & 82518 \\
\hline In-migrations (per 1000) & 6.6 & 7.2 & 10.6 & 13.8 & 8.0 \\
\hline Out-migration & 34091 & 38118 & 48853 & 55830 & 48937 \\
\hline Out-migrations (per 10oo) & 3.8 & 4.2 & 5.2 & $5 \cdot 7$ & $4 \cdot 7$ \\
\hline Population growth (per 1000) & 2.4 & 4.0 & 8.0 & 10.6 & 5.0 \\
\hline
\end{tabular}

Source: SCB (2021)

The latest statistical data indicate that in just a 5-year period between 2015 and 2019, the Swedish population increased almost by half a million people. The high immigration rates contribute to an increase of the younger population as well as to an increase of foreign citizens (ca. 9\% of the population in 2019) and foreign-born citizens (ca. $20 \%$ of the population in 2019).

The labour market participation rates starting from the 1960 s were higher among men for all the age groups compared to later times. As it is seen in Figure 1 and Figure 2, the highest participation rate is among the younger individuals, where in the age group 55-59 years, the average labour market participation is centred around 90\% except for the economic crisis in the 1990s and a decreased rate in the early 200os. The participation rate of this group is the most stable throughout the whole period in focus. The group of the 60-64-year-olds has a lower participation 
rate, which has been decreasing since the 1970s, with an even further decrease in the early 1990s. This group was more affected by the economic crisis than 55-59year-olds. One of the possible explanations can be that older workers have lower formal education levels, which also affects their labour market position (leads to more vulnerable jobs) and makes it more difficult to re-enter the labour market after a period of unemployment (Laun \& Palme, 2018; SOU, 2020:69). Nevertheless, labour market participation in the age group of 60-64 years changed direction during late 1990 s and since then, participation rate has increased substantially due to factors such as improved health, better working environments, higher education levels and changes in social benefit legislation (Laun \& Palme, 2018) However, it is interesting to observe that by 2016 the participation level in this group has not yet reached the level of the 1960 s. The same pattern can be seen among 65-69-year-olds with an even sharper fall in participation rate between the 1960 and the 1990 s followed by relatively stable levels of participation under/around 20\% until slightly increasing around 2010 (Figure 1 and Figure 2). The decrease in the labour market participation and increase in the takeout of an early pension were two trends noticed in the policy debate, though there is not one clear explanation of why this occurs. It is discussed in Chapter 4 more in detail when considering various policies and their effect on late and extended working life, but generally, more research is needed in this area (which is also pointed out in the policy debate, see SOU, 2020:69). 
EXCLUSION AND INEQUALITY IN LATE WORKING LIFE

WORKING PAPER 5:

EXCLUSION AND INEQUALITY IN LATE WORKING LIFE: NATIONAL COUNTRY

CONTEXT - SWEDEN

Figure 1: Labour market participation1 among men in various age groups

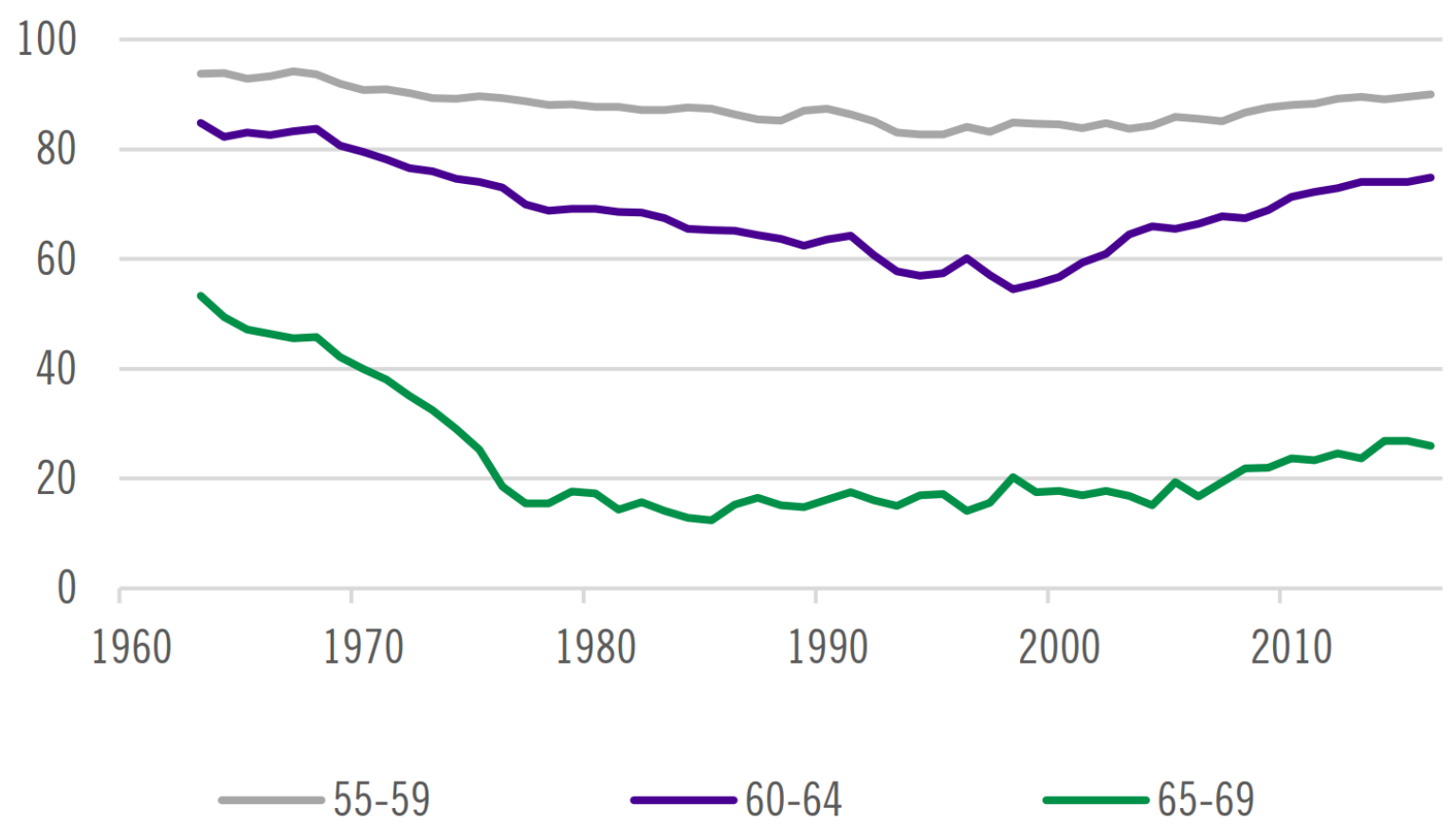

Source: AKU; Laun \& Palme, 2018, p.9.

Female labour market participation has totally different dynamics. Here the gender gaps are particularly visible. The female labour market participation rose substantially since the 1960 s. The increase of female participation in the labour market is not only due to the changing view on gender roles, but also due to policy changes, such as e.g. the discrimination act, which was introduced in 2009 and further developed a former law against gender-based discrimination in the labour market (Discrimination Act, 2008). The discrimination act safeguards gender equality and bans discrimination based on gender as well as harassment and gendered wages (Discrimination Act, 2008). The increase in female labour market participation is especially visible in the two age groups 55-59 and 60-64. Comparing 1963 to 2016, the participation for both groups has doubled. Nevertheless, only during the 1990 s the gap started closing and in the latest years, women in these two

\footnotetext{
${ }^{1}$ Participating in the labour market are employed people, who have performed on average at least one hour work per week during the November month. It also includes temporary absence from the labour market for example for vacation, sickness, or parental leave reasons. Unemployed are defined as active jobseekers, who have been out of work at the time of measurement but are ready to start working (SOU 2020:69).
} 
age groups have started to get closer to the levels of the male participation rate. The group of 65-69-year-olds are represented by less than $20 \%$ still being in the labour market. This rate in the latest years is similar to that of men. However, women in this group have since the 1960 s been inactive in the labour market with a further decrease during the 1980 s and 1990 os and only somewhat catching up with the trend for men around 2010.

Figure 2: Labour market participation among women in various age groups

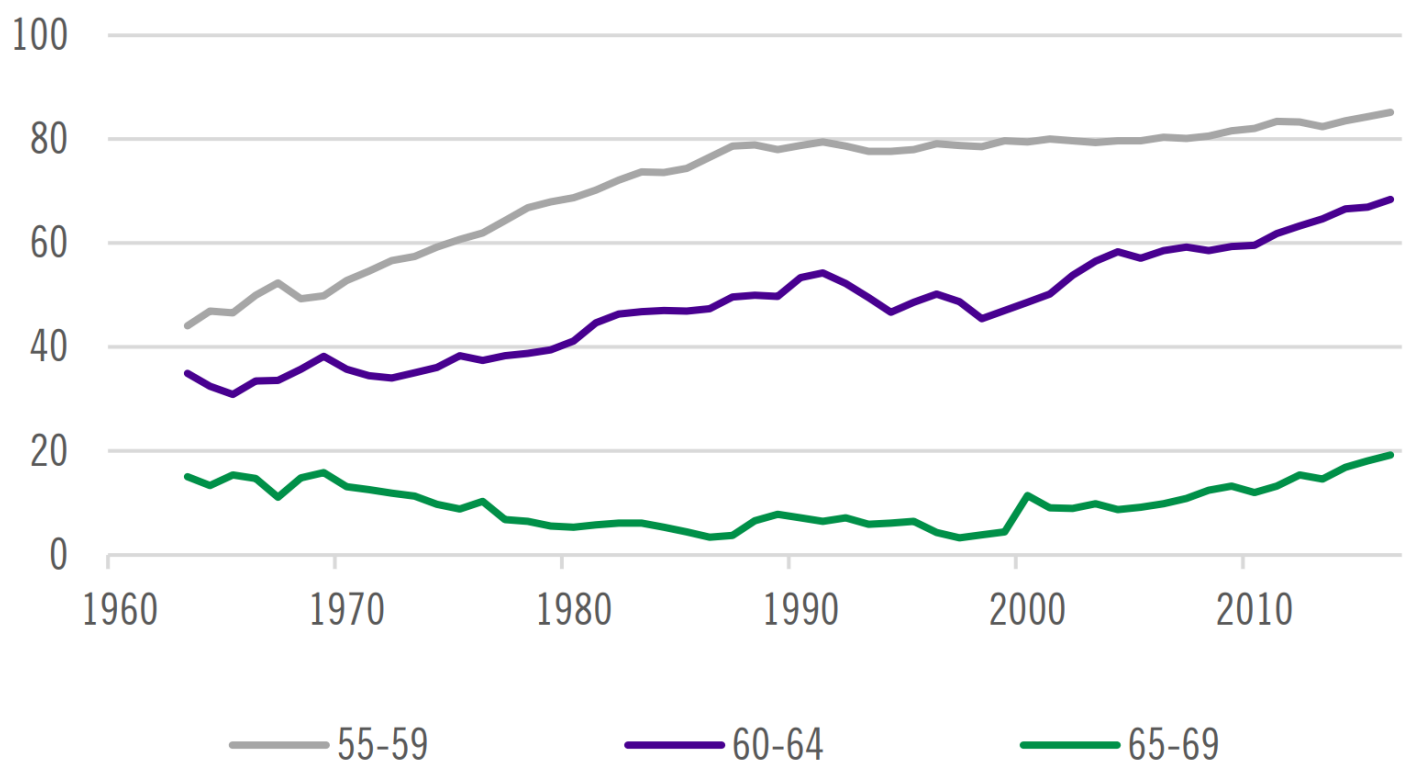

Source: AKU; Laun \& Palme, 2018, p.10.

In their study Laun and Palme (2018) examine the impressive increase in the labour market participation among 60-64 year-olds since the late 1990s and conclude that societal factors, such as improving health as well as higher education levels and the institutional factor of stricter regulations for entitlement to the disability benefit, have had an impact on this trend (for more on the disability benefit, see Chapter 4). Even after impressive growth in labour market participation levels among women, the gender gap is still visible. However, female labour market participation levels in Sweden among 16-64 year-olds are high in comparison to other countries (SOU, 2020:69), even when comparing to neighbouring countries who are developing similar policy regimes like for example Denmark (Jensen, 2020). Nevertheless, when the attention turns to the age groups of 65-69 and 70-74, the situation changes. In 2017, both, men and women had a lower labour market participation rate than the OECD average (SOU, 2020:69).

The current demographic and labour market participation trends result in the increased ratio, where an employed individual supports 0.75 individuals not in the 
labour force. This ratio was 0.71 in the 1970 s and if the trend continues, it will rise to 0.90 in the 2050s. In addition, the number of hours worked during the life is decreasing for both men and women and the share of time spent in retirement is rising. The trends are related to late entrance and early exit from the labour market, i.e., extended time spent in the education and early retirement, as well as increased average life expectancy. Due to Covid-19, unemployment rates raised, but is considered to be a short-term effect, meaning the labour demand would resurge, and labour shortages remain (SOU, 2020:69).

\subsection{Mapping the political-economic policy discourses: framing the late and extended working life}

Research on dynamics in Swedish late working life and changes in retirement policy reveals that these are mainly related to a few major factors. First, there is the labour market demand, which is contingent on shifts in economic contexts and especially sensitive to economic downturns (Laun \& Palme, 2018). Second, dynamics are driven by the (assumed) financial sustainability of the pension system, its capacity to provide decent pensions and to avoid poverty (Engström et al., 2020). Third, they relate to perceptions regarding older peoples' abilities to perform work tasks, which is often expressed as a measurement of the health and longevity of the general population (Laun \& Palme, 2018). Fourth, there are the normative institutional and societal understandings about the working- and retirement age, which drive late working life dynamics (Engström et al., 2020). Fifth and finally, are attitudes, aspirations and decision making in terms of the family situation and needs that are relevant (Laun \& Palme, 2018).

What is peculiar about the Swedish case is that since the initiation of the state pension system in 1913, the pension age was 67 years, but it was reduced to 65 years in 1976 (Engström et al., 2020; Laun \& Palme, 2018). Currently, there is no state pension age in Sweden, except of the minimum age limits to access various parts of the pension. In addition, many age barriers exist in various security systems, which makes certain institutional and normative markers for taking a pension at the age of 65 (see Chapter 4). The effective retirement age -64.6 years in 2018 (Pensionsmyndigheten, 2020a), is in comparison to other European countries relatively high (SOU, 2020:69).

The debate on late and extended working life re-entered the Swedish political agenda between the 1980 s and early 1990 s and concluded with the reform of the gradually implemented pension system in 1998 and 2001 (with full effect in 2003). The key changes of this reform were that pension benefits became more strongly related to the contributions, the minimum age was raised, and a higher gross replacement rate was ensured for those, who retire after the age of 65 (Engström et al., 2020). The Swedish public pension system changed from 'defined benefit' to 'defined contributions' (Blomqvist \& Palme, 2020, for more information on the 
pension system see Chapter 4.1). Benefits were no longer defined beforehand, but were flexible and dependent on changes in economy, salaries, and population ageing (Blomqvist \& Palme, 2020). Also, the private pension system became more flexible, as e.g. pension funds can be chosen by the individuals (Blomqvist \& Palme, 2020). The initiated changes were based on the increasing share of the older population, on young people entering the labour market later and the issues these trends can present for the financial sustainability of the pension system (Engström et al., 2020). Bearing in mind the economic downturn in Sweden in the 1990s, the overall labour demand and employment rate was lower for all the groups in society. It was observed though that the employment rate among the age group of 65-69 year-olds is considerably lower than that of the 60-64 year-olds, even though life expectancy and self-reported health did not present the same gap. This is a trend that continues to recent years (Laun \& Palme, 2018; Figure 1).

A decade later, in 2011 after an evaluation, the pension reform of 2001 was deemed insufficient to increase participation of older people in the labour market (Engström et al., 2020). Even more recent research does not have strong evidence that the steep increase in labour market participation among older individuals is an outcome of the reformed pension system (Laun \& Palme, 2020). The Government Commission was formed, which suggested the further prolonging of the minimum and guarantee pension ages. As of January $1^{\text {st }}, 2020$, the minimum pension age was raised from 61 to 62 years. The guaranteed pension (a benefit for those without rights to a state pension) age will be raised from 65 to 66 years in 2023 and the pension age will be adapted related to the average life expectancy from 2026 onwards (see Chapter 4 for more details).

On the working life side, the most influential policy shaping the retirement is the Employment Protection Act (LAS). The idea of reduced employment protection for older individuals was introduced in the 1970s. It was formulated as LAS in the early 1980s. LAS defined a new age barrier (67 years) and allowed to lay off employees based on old age for one month before they turned 67, during the so called 'window'. After this 'window' has passed, employers again were obliged to present a valid reason for the lay-off, but the period of notice (uppsägningstid) was shortened to one month and employees were removed from the priority list (Ds, 2018: 28; Lowen, 2016). For instance, in case of reduced labour demand, employees over 67 years would then be more vulnerable to job loss.

The main idea behind introducing LAS in the 1980 s was to facilitate laying off employees to make the transition to retirement more 'decent', avoiding individual court cases and the situation where employers would look for evidence to prove an employee's inability to perform their tasks due to their age. It was also related to the discourse that people at this age (67 years) often have lowered capabilities to work (Lowen, 2016). This policy of reduced employment protection for older workers is also in line with the argument of Perez (2002). Perez (2002) states that, historically in world economy, before reaching a 'golden age', a laissez-faire attitude is usually 
assumed in policy to ensure a period of high competition and development of a new paradigm. This laissez-faire approach often entails less employment protection by the state.

Most recent changes of LAS were initiated by the major political parties (Swedish Social Democratic Party, Moderate Party, Liberals, Centre Party, Christian Democrats and Green Party) in the so-called pensions agreement (Pensionsöverenskommelsen) in 2017. The agreement is based on the reasoning that the Swedish population's life expectancy is increasing and to sustain the funding of the pension system, which also provides higher pensions, the working life needs to be extended (Ds, 2018: 28). A Government Commission was formed, which suggested the further prolonging of the employment protection age. As of January $1^{\text {st }}$, 2020, the LAS age limit is raised from 67 to 68 years and as of January $1^{\text {st }}, 2023$, from 68 to 69 years (Engström et al., 2020; Laun \& Palme, 2018; see Chapter 4).

As most recent studies (Engström et al., 2020; Krekula \& Vickerstaff, 2020) indicate, current policies prioritize delaying retirement by increasing the statutory pension age rather than supporting the extension of working life by active labour market or qualification measures. Even though there are policy discussions about late and extended working life, e.g. concerning ageism as stereotype or discriminatory practice as well as concerning sustainable and flexible working conditions suitable for workers of all ages, only limited attention is paid to the variety of situations encountered by different groups of older people (Engström et al., 2020). Older people are still identified as a homogeneous group and inequalities by gender, class and ethnicity as well as differences in health, employment status, workplaces and competing obligations in family and work are widely disregarded (Engström et al., 2020; Krekula \& Vickerstaff, 2020). In addition, late working life policies are framed in relation to broader social, political, and economic discourses.

Nevertheless, in Sweden population ageing is also connected to increased debates about welfare funding and the need for active and healthy ageing for increased late labour market participation, to maintain productivity as well as to generate revenue improvements and reduce expenditures in the health care and pension system. Swedish healthcare is chronically undercapitalized, and it is especially the provision of eldercare that was privatised and marketized, resulting in increased risks for inequalities in the care system (Andersson \& Kvist, 2015). Moreover, the now adjusted pension system is only partly providing decent standards of living due to decreased replacement rates. The current replacement rates are at $53.4 \%$ of the pre-retirement earnings (OECD, 2018). The system succeeds in reducing poverty to an ever-lesser extent, especially among those with low income and interrupted careers (Hamskär, 2020), where the state old-age pension (the income-based pension or guarantee pension) constitutes the main source of the income (Ministry of Health and Social Affairs, 2016). 
A recently produced report by the 'delegation for older labour'' (delegationen för senior arbetskraft) points out three possible solutions for the issues related to low pensions and the overall welfare financing. Firstly, by raising taxes (including the contributions to the pension system), secondly, by reducing the standard of the public services as well as the level of benefits, thirdly, by raising the number of hours worked in the whole economy. The productivity growth, on the contrary, is not seen as the solution since the public costs grow in the same vein or even faster than productivity. The increase of the total amount of hours worked in the economy is presented as the best solution. It can be done in a few ways or combinations of various ways, which include several groups of the society. Young people, who could start working careers earlier (it takes longer time for students to be done with their studies); part-time workers could start working more hours, unemployed people (jobseekers, individuals on long-term sick leaves or disability benefits) could start working or workers in late working life could delay their retirement. The last option is thought to be the most gainful (SOU, 2020:69). This conclusion also signals that possibilities to enter the labour market are seen as more limited than the chances to remain in the labour market. Thus, unemployed young people or those with poor health stand further from the labour market and likely have less chances of a successful integration than the already established older population. This is an interesting line to follow in relation to other political-economic and social discourses in Sweden.

Older people are often described as 'a problem' in public discourses (Krekula \& Vickerstaff, 2020), which feeds into another strand of discourses on citizenship, social rights and solidarity. This discourse manifests itself in the debate on (un)deservingness of the welfare entitlements. Especially in recent years, since the so-called refugee crisis in 2015, refugees are sometimes put against other society groups such as pensioners, those in need of health and care support (Dahlstedt \& Neergaard, 2019; Hansen, 2018). Sweden is known for welcoming refugees and experienced a wave of newcomers from the Balkans in the 1990s. Since 2008, Sweden had one of the most liberal immigration laws that allowed both labour migrants and refugees to enter the country, allowing family reunion (Schierup \& Ålund, 2011). The discourse around the liberalization of immigration was twofold. On the one hand, a pledge for humanitarian cause and on the other hand, the expectation that the newcomers will integrate into the labour market and support the increasing needs of the ageing Swedish population. The discourses shifted very

2 The 'delegation for older labour' is a special commission, which was established by the Government and Pensions agreement group (Pensionsöverenskommelsen) in 2018 in order to promote inclusive late working life, tackle age discrimination and utilize the skills of the older workers. The Commission has published 23 reports mainly written by scholars outside the group and released a final report with the policy guidelines (seniorarbetskraft.se). 
quickly since 2013, when a wave of refugees reached Sweden. Since then, the surfacing discourses indicate that instead of becoming a 'promised labour force' and supporting the generous welfare state, the refugees fail to integrate into the labour market and became an additional burden on welfare (Hansen, 2018). Thus, in the interplay between welfare and labour market institutional contexts, older people can be depicted as the 'victims' and refugees as the 'scapegoats'. In other words, signifying who is 'the Other' in any given society and indicating the crisis of solidarity (Dahlstedt \& Neergaard, 2019).

Another type of solidarity issue is the one between the younger and older generation. On the one hand, unemployment among young people is higher than among the older cohorts of the population (SOU, 2020:69) and there are greater policy efforts to integrate youth into the labour market than to extend the working life. Thus, it could be seen as a competition in the labour market, where the older generation should retire and allow younger people to step in. This understanding assumes that there is a limited amount of labour demand in the country. The evidence from the literature suggests the opposite, namely, that the growing labour supply is also related to the growth in labour demand (SOU, 2020:69). Moreover, measures reducing employment among older people have the same impact on the employment among younger people (SOU, 2020:69).

The active labour market policy efforts to enter or return to the labour market are not prioritizing older people. If to only look at the variety of programs provided by the Swedish Public Employment Service (Arbetsförmedlingen), all of them have the upper age limit that is 65 years. While there are special programs directed towards youth (Employment guarantee-Jobbgaranti för ungdomar) and newly arrived immigrants, mainly refugees (Establishment program Etableringsprogrammet), there are no direct inputs for older people (Arbetsförmedlingen, 2021). However, the latest report by the above-mentioned authority showed that older people once unemployed risk being unemployed long term and have more difficulties to return to the labour market, hence they can get trapped in unemployment situations. Unemployment can be caused by a mismatch between skills and demands (more on that in Chapter 2.2.3), for which older workers are more vulnerable as they are less likely to participate in informal education, even though job-related skills are quickly outdated nowadays (Landell, 2016). This risk grows with rising age, where the oldest in the labour market are most likely to be affected (Landell, 2016).

The above-mentioned discourses of solidarity are an actual manifestation of the much longer trend of austerity and welfare dismantling in Sweden (Hansen, 2018). It was previously described as the 'end of the Swedish exceptionalism' (Schierup \& Ålund, 2011), where back in the 1990 S Swedish universal social democratic welfare regime caught on the global neoliberalism trend that started in other countries in the 1970s. This appears to be in relation to the economic crisis and less driven by political powers, especially when it comes to reforms in the pension system (Hagen, 
2017). The neoliberal discourse indicates that a generous and universal welfare state is not compatible with economic growth and the creation of jobs. Thus, there has been an increased emphasis on economic growth, which would in turn benefit the creation of jobs and enable the individuals to ensure their welfare from the market (Schierup et al., 2006). However, the state (and taxation) has still played a larger role in Sweden than in many other European countries.

Blomqvist and Palme (2020) provided an overview of changes in the level of universalism in the Swedish welfare model since the 1990 s caused by the economic crisis and neoliberal ideas. The selected areas of social insurance (unemployment and sickness benefits), pension system, family policy and health care underwent changes, which were evaluated based on four dimensions of the universalism. Namely, (1) inclusion, which shows the coverage of the programs as well as formal eligibility and access among the individuals; (2) financing programs publicly or privately; (3) provision, referring to service providers, which can be public, private or non-profit; (4) benefits, which defines the adequacy of the benefits and if alternatives in the private sector are needed. They conclude that at least three out of four dimensions of the universalism were reduced with the biggest effect on the provision of services. The most affected areas are social insurance and pensions, where partial privatization of the financing of these programs led to slightly decreased universalism. The universalism was further decreased when it comes to marketization of provisions and reduced adequacy of the benefits. The latter refers to the stricter access regulations, lowered caps for benefits and decreasing replacement ratio. Thus far, the highest risk of a further decrease in universalism is identified in the privatisation of service provision. Since service provision is administered by various actors, which often creates less effective cost control, there is a reason to call for a diversified and potentially less equitable, more stratified system (Blomqvist \& Palme, 2020).

Table 2: Changes in dimensions of universalism in Swedish welfare 1990-2019

\begin{tabular}{lllll}
\hline & Inclusion & Financing & Provision & Benefits \\
\hline Social insurance & constant & slightly reduced & reduced & reduced \\
Pensions & constant & slightly reduced & reduced & reduced \\
Family policy & extended (childcare) & extended & reduced & extended (childcare), mixed (parental insurance) \\
Health care & extended & constant & reduced & mixed \\
\hline
\end{tabular}

Source: Blomqvist \& Palme, 2020, p. 121.

The Swedish welfare model is based on universalistic ideas, where a generous welfare state should be compatible with the market economy. This model is based on a dual-earnings approach and has a high labour market participation among both genders. The work-life balance is good, where the family policy is generous, 
and the care (child and elderly) systems are well developed (Blomqvist \& Palme, 2020; Esping-Andersen, 1990; Magnusson, 2007). The social policy is more geared towards enhancing equality (more focus on gender, ethnicity and income redistribution) rather than life-course policy. The latter comes more into the picture in recent debates on lifelong learning policies.

Poverty and inequality connected to flexible and precarious employments is identified as one of the key social risks in Sweden. It specifically affects women and young people. It is highly ethnificated (Guilherme Fernandes, 2013; Wikström \& Ahnlund, 2018) and geographically dispersed (Scarpa, 2013). The biggest issues are arising in segregated areas, where ethnic concentration and economic segregation form a conjoint relationship (Malmberg \& Clark, 2020), urban housing policies have been rolled back and living in such an area thus means a higher risk of poverty and social exclusion (Thörn \& Thörn, 2017).

One of the biggest challenges for older people in Sweden is that flexible and precarious employment creates not only low income while still in the labour market, but also makes low contributions to the pension system. It also constitutes interrupted careers, which again means lower contributions to the pension system. Precarious employment can also mean a stable contract, but difficult working conditions that affect individuals' health and workability and can lead to an early retirement. Due to the multipillar nature of the latter and the fact that pensions are earnings and work-time related, these labour market disadvantages are further translated into pensions. Even though, in comparison to other European countries, the Swedish pension system ensures a better living standard, poverty and social exclusion in old age still exists (Ebbinghaus, 2019). The most disadvantaged groups are correlating to the above-mentioned groups, which generally are more likely to be in flexible and precarious employments. The degree of poverty and social exclusion in older age depends on the (un)employment history throughout the life course and whether precarious and flexible employments lasted during the whole working life or just in some phases (e.g. women who have a higher share of care for children and elderly).

Female labour market involvement and gender equality in care is a high priority in Swedish policy. Since the 1990s, family policy underwent various changes and one of the main consequences has been increased participation of men in parental leave schemes. The institutional network of child-care has also expanded vastly, allowing parents to get better access to it. Most child-care institutions are publicly administered (Blomqvist \& Palme, 2020).

A somewhat different trend was visible in health and elderly care. Even though the health care institutional network is quite extensive, marketization has reduced its universalism (Blomqvist \& Palme, 2020). Swedish healthcare is chronically undercapitalized, and it is especially the provision of eldercare that was privatised and marketized, resulting in increased risks for inequalities in the health and longterm care system (Andersson \& Kvist, 2015). 
Concluding, the Swedish welfare state has undergone several changes in the last decades and reacted to challenges in different ways. The topic of working life exit and pension is rooted in the core of these developments. Although the labour market participation among people aged 55 to 69 years has been increasing since the 1990 , pensions are still considered low and welfare financing is brought to the fore on political agendas. Prolonging working lives is considered the most gainful solution to welfare financing shortages.

\section{Late and extended working life: the Swedish social model, labour market actors and current policy positions}

\subsection{The Swedish social model and main labour market actors}

The Swedish (also Scandinavian) social model is widely known for defining specific relations among employers' organisations, trade unions and the state authorities. This model was established back in the 1938 in the Saltsjöbaden accord (Dahlqvist, 2020). It entails a high labour market regulation based on consensus among trade unions (TUs) and employers' organisations, whilst the state does not play a formal role in the industrial relations. Its responsibilities are to ensure a macroeconomic context where full employment based on a dual earnings model (thus, more gender equal) is possible, to promote active labour market policies and to organise the education system (Esping-Andersen, 1990; Magnusson, 2007; TCO, 2020a). Even though there is a lot of training and education occurring through employers (Chapter 3 shows that it is more accessible and more often used by younger employees), the main obligation for the education lies with the state and the individual. Companies are responsible for training in job tasks and occupational health and safety. Moreover, companies are active in training their staff and buying specialized education from universities or private actors (SOU, 2015:70; Nordström et al., 2016; ETUI, 2020).

Education in Sweden should be accessible for all and is free of charge (even higher education). Developed student loan systems ensure a possibility for individuals to continue education or skills development without being dependent on the market (CSN, 2020). In recent years, lifelong learning policies received more attention. Against this backdrop, the accessibility of vocational and higher education expanded and suggestions for increasing the age limit for student loans and introducing a comprehensive lifelong learning policy are in place (Regeringen, 2019; Regeringen, 2015; Regeringen, 2020 a,b; Nordström et al., 2016). The aim of 
this policy is to see education and work as a one process, where the periods of updating and developing skills as well as requalifying are integrated in every working life (Nordström et al., 2016; see Chapter 4).

In case of requalification needs, the state comes into the picture by combining the education system with active labour market policies, which provides an avenue of support for individuals to change their careers and professions/branches, including the services provided by the Swedish Public Employment Service (Arbetsförmedlingen). This institution works with unemployed people and provides services of coaching, organises retraining and has a database where job vacancies are announced. In 2019, the institution undertook a reorganisation and most of its functions became privatised. The Swedish Public Employment Service now has a coordinating and controlling function of the private service providers. The state is also responsible for the establishment of the universal and high-quality welfare provision and for income redistribution through taxation, promoting equality (Esping-Andersen, 1990; Magnusson, 2007; TCO, 2020a).

The model combines the interests of labour and capital by mainly using collective agreements. Those agreements regulate the labour relations at the sectoral level. Since the Swedish labour market is highly regulated by the social partners, TUs and employers, such state authorities as the Swedish Work Environment Authority (Arbetsmiljöverket) have more of an advisory role rather than a more coercive one, which is prevailing in other Scandinavian countries (Nielsen, 2017). The collective agreements among the social partners also regulate the wage setting, thus Sweden does not have a national minimum wage. Instead, there is a variation of wage rates depending on the sector.

The Swedish model is characterised by having strong trade unions, where the union density is one of the highest in Europe (according to OECD, 65.6\% in 2017). These unions not only represent the workers, but also give access to the health and wealth insurances as well as unemployment insurance for its members (TCO, 2020a).

\subsection{Labour market actors and current policy positions}

This section continues discussing the positions represented by the labour market actors who are actively expressing their opinions in the public space and who are contributing to the policy formation. Both, their official websites and statements in the public media are considered. These selected main actors are:

- $\quad$ LO - The Swedish Trade Union Confederation

- $\quad$ TCO - Swedish Confederation of White-Collar Workers

- Byggnads - Swedish Construction Workers Union

- Svenskt Näringsliv - The Confederation of Swedish Enterprise is Sweden's largest and most influential business federation 
- PRO - The Swedish National Pensioners' Organization

- SPF Seniorerna (further - SPF) - The Swedish Association for Senior Citizens

- State/government

\subsubsection{Gendered labour market inequalities and poverty: pay gap, care gap and pensions gap}

Back in 2014 and 2015, PRO released reports about poverty and inequality among pensioners. The two biggest issues raised by the PRO are the increasing number of pensioners falling below the poverty line as well as the low replacement ratio, i.e., the relation between the pension rates and salaries. In the Swedish pension system, the pensions are taxed. Currently, some pensions suffer from higher taxes than salaries of the same size. This inequality in comparison to the labour market income is emphasised by the fact that some pensions are so low that people end up below the poverty line. Those who are mainly affected are low-income earners and a vast majority of them are female. In 2013 in Sweden, male pensions were on average ca. 1.5 times higher than female pensions (PRO, 2015). As salaries have a big impact on pension amounts, the gender difference in pensions can be traced back to a gender difference in earnings during the working life (PRO, 2015). In 2014, women in Sweden earned on average $25 \%$ less than men (PRO, 2015), which constitutes an increased risk for women to fall below the poverty line as pensioners. PRO is pointing out that low female pensions and dependency on the guarantee pension (see more in Chapter 4) are partly a result of the unequal labour market, where females often end up in the low-paid sectors (mainly in the welfare sector) and are more often trapped in flexible and part-time employments which affects their income (PRO, 2014, 2015). There is a lack of research on how flexible employment affects the likelihood of working in older age (Engström et al., 2020). Some previous reports indicate that these types of employments can have ambiguous effects. When it is seen as a possibility to get flexible working hours or tasks, it might postpone the retirement (Arnek, 2012). On the other hand, when flexibility is involuntary, as is common among women in the municipal care and welfare sectors, it can over time lead to weakened connection to the labour market (Wall, 2014) or possibly earlier exits. Further, the gendered part-time employment inequalities depend also on care responsibilities. Here, women more often than men reduce their labour market participation to take over care responsibilities for an older family member (Szebehely, 2014).

The above-mentioned employment and income inequalities are also later reproduced by the pension system and translated into differences among pensions, which has an earnings-related part. In addition, those in, often involuntary, insecure employment tend to lack occupational pension agreements with implications for future pension income. In their reports, PRO suggests raising the guarantee pension as well as the income-based pension rates (PRO, 2014, 2015). 
According to the latest agreement by the intra-parliamentary 'pensions group' in 2021, the basic pension rates will be raised for those who are getting the lowest pensions. PRO welcomes the changes but highlights the importance of a more basic reform of the pension system that is not only financially sustainable, but also ensures a decent living standard for the current and future pensioners (Hamskär, 2020). In other words, more reliability on the income from the labour market would lead to increased inequalities among pensioners and strongly disadvantage women. There is a need to reduce the share of flexible and insecure employment (with more quality and sustainable jobs within the welfare sector) as well as to raise structurally low salaries in the female dominated sectors (PRO, 2015), although flexibility prior to retirement can be popular. Keeping in mind the inequalities stemming from the labour market, stronger redistribution via the welfare system is needed and cuts in taxation are discouraged with exception for the reduced taxation on the pensions 3 (Hamskär, 2020).

The questions of gendered labour market inequalities are one of the central questions for the trade unions and their confederations - TCO and LO. The main issues named are similar to those raised by PRO: unequal payments as well as flexible and underpaid employments that prevail in the female-dominated sectors. Furthermore, the trade unions and their confederations also call out the unequal share of care responsibilities in terms of parental leave, care for sick children and household work (Bergold, 2020). The latter is one of the main factors that translates into an unequal share of part-time work (women who have small children more often shift to part-time employments), salary and pension differences. Hence, the parental leave is seen as an important tool to balance out these inequalities. Having in mind low-paid female dominated sectors, it is important that individuals get a decent payment, which also corresponds to their education and responsibility level despite of working in the low-paid sector (Svanström, 2020).

\subsubsection{Labour conditions: adjusted working tasks, sustainable working places and ageism}

TCO (2020b) and SPF (2020) argue for the importance of having sustainable workplaces that do not lead to 'worn-down' employees, adjusting tasks for employees according to their skills or providing opportunities for further training and education. It is also important to offer flexible working hours. According to TCO (2020b), all the above-mentioned factors increase the ability and willingness of

${ }^{3}$ For the impact of changing pension policies such as increased retirement age, greater individual responsibility, impact on labour market trends in later working life, see Chapter 4. 
older people to extend their working lives. Of course, this depends on health, caring responsibilities, and whether people can afford to choose not to work.

It also depends on the attitudes towards older workers or rather a change in attitudes, shifting towards viewing older people as potentially equal contributors to the labour market. SPF formulated the issues of ageism into a political agenda document that calls for 'respect for the older people' in society at large, but also specifically in the labour market (SPF, 2017). The issues of ageism and age discrimination are relatively recently acknowledged in legislation - discrimination based on age was included in the Discrimination Act only in 2009 (DO, 2020). The research has clearly shown that older people are discriminated against in the labour market (Ahmed et al., 2012; Carlsson \& Eriksson, 2018), though it is still not clear to what extent this discrimination affects the retirement decisions (Engström et al., 2020). Besides of changing the employers' attitudes and seeing older people as potential workers - thus a solution to the labour market problems - SPF (2017) argues that it is also important to address the various discriminatory age barriers in legislation. One example of discriminatory age barriers in legislation is the age limit defined in the Employment Protection Act, the so called 'LAS' age, meaning that individuals older than a certain age (currently 68 years) have lower employment protection (SPF, 2017; see more in Chapter 4).

PRO and Byggnads point out that sustainable working conditions are a must because people in physically and mentally demanding jobs already now are struggling to work until the current pension age. This discussion is especially relevant in the wake of the coming introduction of a prolonged retirement age, which will be introduced in more detail in Chapter 4 . The above-mentioned trade unions and pensioners' organizations clearly point out that it has not been done enough in terms of improving labour conditions and combatting ageism in the labour market to extend working life, but that the focus until now rather lies on postponing the retirement.

\subsubsection{Skills miss-match and labour force shortages}

Both trade unions and employers' organisation agree that the Swedish labour market is dynamic, many new jobs are created, and many are lost (within a year, around 450 thousand out of 5 million jobs). People change jobs and move between branches. But the labour market also has a big problem with the miss-match. While some branches suffer from the labour force shortages, unemployment exists. In other words, there is no lack of labour force per se, but it is a lack of the right kind of skills. The issue of securing the needed skills is acute for the Swedish labour market to maintain healthy economic growth, international competitiveness and welfare (TCO, 2020b; Svenskt Näringsliv, 2020). On the one hand, the TUs argue for investing in the employees' skills via education and training to increase competitiveness and reduce the unemployment rate (TCO, 2020b). This is especially benefitting older workers, who are, once unemployed, more at risk of 
becoming long-term unemployed compared to their younger counterparts, partly due to lower participation rates in informal trainings, which can lead to outdated skills (Landell, 2016, Lindell, 2018, Arbesförmedlingen, 2021). Contrasting the TUs arguments, the employers' organization pays more attention to facilitating replacement of employees who do not have the required skills. On the other hand, the employers' organization is very active in driving simplified procedures for bringing labour from abroad. The current policy is seen to be too rigid and vesting the local workers' interests as it allows the hiring employees from abroad only if there is a labour force shortage in Sweden and the right kind of skills are not found in the country. The employers' organization is also raising critique for the migration policy regarding the complicated procedures for attaining all the needed permits and visa documents (Svenskt Näringsliv, 2020). This indicates certain priorities among the employers regarding various societal groups and their employability. The easier access to the labour market by foreign workers might also mean less attention to older workers already living in the country.

Trade unions express support for open markets and free movement of labour within EU and distance themselves from the labour market protectionist strategies (TCO, 2020b). What is more prominent on the TUs agenda is the need for securing the same labour and social rights for all workers. Thus, the foreign labour force and newly arrived refugees who are striving towards establishment on the labour market should be treated equally in terms of salary and labour conditions, integrated into the Swedish model and covered by the collective agreements (LO is active in promoting these aspects; LO, 2020). That is to not cause wage and social dumping, which means that cheaper labour from abroad presents a risk for decreasing salaries and endangering labour conditions in Sweden. The employers' organization is also putting a lot of attention to questions of diversity and integration but focuses more on benefits for the individual workers, company growth and increase in international competitiveness (Svenskt Näringsliv, 2020).

\subsubsection{Possibility and a need for life-long learning}

Life-long learning questions are important for both partners (TUs and employers). Both, the current demands and skills shortages as well as the future labour market needs are intensively discussed. In the light of a prolonged working life, there will be more need for an individual to change jobs or even occupations. Moreover, the dynamic labour market requires a constant development of skills and knowledge (TCO, 2020b). The main question is how to achieve this. Since the responsibility for education mainly lies on the state and the individual, the practices at the branch or company level are quite individualized (see more in Chapter 4). The employers' organization pays more attention to education that starts at school and calls for a focus on entrepreneurship. It also addresses the higher education institutions as well as vocational education providers and calls for a closer matching between knowledge and skills provided there and labour market needs. Moreover, the 
employers' organization is discussing possible closer collaborations between the employers and educational institutions (Svenskt Näringsliv, 2020). These initiatives would primarily address the younger population.

Among the trade unions, TCO has been active in promoting questions of life-long learning. The main point here is that employees need to have opportunities and conditions to be able to develop during the whole working life. There is a need for a new area of policy - competence/skills (kompetensförsörjning) policy - that encompasses labour market, education and business policies. Ensuring continuous education and training throughout a working life, especially having in mind older workers, requires the more prominent role of universities and professional education schools (yrkeshögskola), better financed studies (possibilities for study loans), easier entrance to various education institutions (for instance, that working experience can be taken into account) as well as more flexible and individualized learning possibilities (e.g., entering education that does not necessarily correspond to the previously attained education). There is a general need for a circular movement between education and labour market. Not only unemployed people in need of a job should have access to education, but also employed people. This is to keep up with the demand for skills at the current workplace, expand career possibilities or change of branch (in this way employees can be attracted to the areas where labour force is lacking). Here not only the national, but also the regional policies are very important. The disparities among the municipalities in relation to access to education are wide (TCO, 2020b).

\subsubsection{Swedish social model and the challenges of EU common market}

As it is presented above, the Swedish (Scandinavian) social model is based on the strong collaboration between the social partners, TUs and employers' organisations in industrial relations, while the state covers the labour market policy issues and creates the political preconditions for full employment and universal welfare.

The Swedish labour market is highly regulated by the social partners and was lately challenged at the European level. First, by the free movement of services and posting of workers practices, where companies from other member states were providing services in Sweden and adhering to the regulations of the country of origin (e.g., a construction company from Latvia) for salary and working conditions. The conditions and salaries were lower than the Swedish standards described in the collective agreements and induced a reaction from the TUs (Woolfson et al., 2010). For instance, the TCO points out that it stands for the free movement of services and encourages the international competition, but it sees as its task to explain and promote the Swedish social model with strong trade unions and collective agreements at the EU level (TCO, 2020b).

Another moment unveiling the clash between the EU common market (social pillar) and the Swedish model is the discussion on an EU wide minimum wage. All the social partners, TUs and employers' organizations as well as the Swedish 
Government are making statements against the EU minimum wage implementation in the form of the Directive. It would not only go against the established collaboration and collective agreement principles among the social partners, but also threatens to reduce salaries in Sweden, because Swedish salaries are higher than the possible EU minimum wage (Dagens Nyheter, 2020; SVT, 2019).

Moreover, TCO (2020b) underlines that a highly regulated labour market can also be flexible. It is important that even the temporary employments would be included in employment protection. This would affect extended working life, having in mind the above-mentioned gendered labour market inequalities and involuntarily flexible part-time employments.

\subsubsection{Employment security and flexibility}

One of the most interesting debates in the recent years are regarding changes in the Labour Protection Act, so called 'LAS'. These changes have already come into effect implying that from 2020 January $1^{\text {st }}$, the employment security age (so called 'LAS age', the limit until which a person has a priority on keeping the employment in the cases of decrease in labour demand or reorganization at the company) is raised from 67 to 68 years, and from 2023 January $1^{\text {st }}$, from 68 to 69 years.

The changes were welcomed by the PRO and deemed as less discriminatory in terms of age, because the so-called 'window' was removed and age cannot be used as a ground for laying off employees (Tallberg et al., 2019). Thus, it should be stated here that the increase of the 'LAS age' does not mean more protection for all the workers, but just more protection for the older workers.

When these changes were initiated, they attracted a vast attention from the social partners. The employers' organization became very active. They were trying to use the momentum to advertise for larger reforms regulating labour protection on a larger scale. Claiming that security in the labour market is important, employers were arguing for more flexibility in employment relations. They were addressing the questions of the employers' rights and the need to have more dynamic labour force changes. Accordingly, LAS is inhibiting companies' economic growth and limits job growth (companies' possibilities as well as willingness to create jobs/employ). There is a view that LAS is outdated, does not keep up with the fast-changing demand for skills and thereby inhibits Swedish companies' international competitiveness (Svenskt Näringsliv, 2020). Whilst the Government/ Minister for Labour market, PRO and TUs were pointing out the importance to protect older peoples' employment (Dagens Industri, 2018), the employers' organization argued that the LAS system prevents people without experience and/or higher education to access the labour market and thus inhibits their integration. According to the employers' organization, it also inhibits companies' possibilities to secure the human resources with the needed skills and competence exchange (Svenskt Näringsliv, 2020). According to TCO, if the aim is to create a more competitive Sweden with a lower unemployment rate, there are much better 
ways to increase the labour market dynamics: instead of changing LAS, more investments into education and training should be done. The employees who have worked for a longer time could have more possibilities for part- or full-time education and training to upgrade their skills in the current profession or to change the branch (TCO, 2018).

Another important moment in this debate was that the employers' organization cooperated with the party alliance (the political alliance of the parties in Riksdag) when proposing changes in LAS. TCO emphasized that the employers' organisation is trying to circumvent the common practice of social dialogue among the social partners in the labour market, where the negotiation regarding employment protection and working conditions is handled in consultation with the trade unions and is noted in the collective agreements. Instead, employers are taking a 'path of legislation' and are 'playing political games'. In other words, employers' organisation's strategy is threatening the established order and power dynamics among the labour market actors as well as diminishing the impact of the trade unions (TCO, 2018).

To conclude, the Swedish social model is an elaborate system and labour market is shaped by different actors, including trade unions, employers' organizations and the state. Seniors' organisations like PRO and SPF represent the interest of older generations in the welfare state and specifically in the labour market. These organizations take a stance against ageism and poverty among pensioners and seek to improve employment security and flexibility in late working life. On the other hand, employers' organizations want to keep LAS in place and instead invest in training and education. Thus, late working life is increasingly emphasised in the policy discussions.

\section{Late working life: patterns, characteristics, and inequalities}

Prolonging late working life is viewed as a possible key to different challenges, such as low pensions or welfare financing. Therefore, it is important to understand developments in late working life as well as demographic developments to assess chances and risks of late working life policy making. Hence, this chapter analyses patterns, characteristics, and inequalities in late working life. 


\subsection{Labour market participation}

\subsubsection{Health and life expectancy are increasing faster than labour market participation rates}

As it was briefly presented in Chapter 1, the labour market participation among older people (especially for 60-64) has been increasing since the late 1990s. On the other hand, studies show that life expectancy and self-reported health is increasing faster than the labour market participation rate at the older age (Laun \& Palme, 2018). Figure 3 and Figure 4 demonstrate the objective indicators of mortality rates and labour market participation rates in 1985 and 2009. It clearly shows that life expectancy has been growing, but labour market participation is lagging behind. The gap is especially visible for men, which can be explained by the fact that life expectancy for men was growing faster during the last decades.

Figure 3: Labour market participation rate and mortality rate for men (in 1985

Labour market and 2009)

participation rate

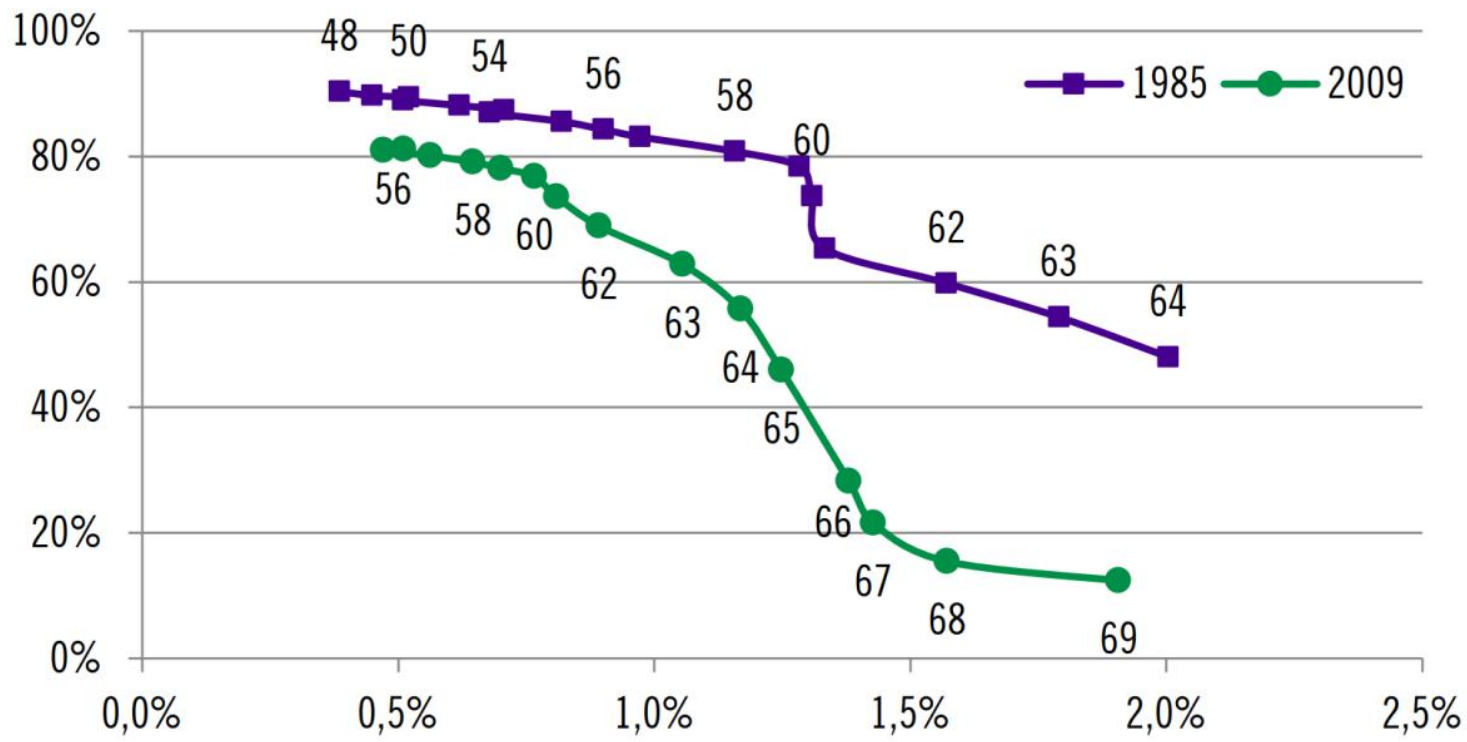

Source: Dödsorsaksregistret, LOUISE-database; Laun \& Palme, 2018, p.25. 
Figure 4: Labour market participation rate and mortality rate for women (in 1985 and 2009)

Labour market participation rate

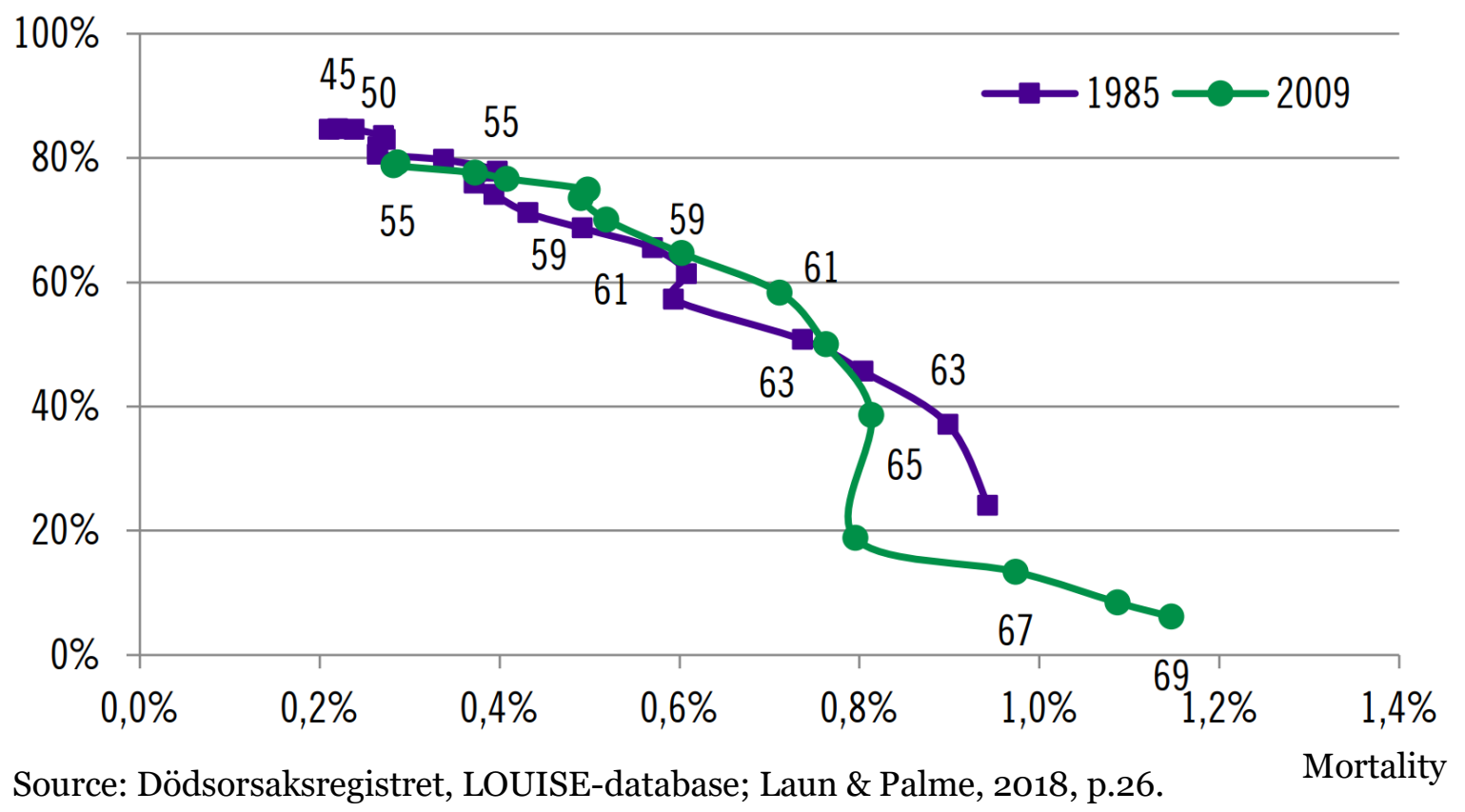

Objective indicators, such as mortality rate, might not reveal the full picture of the population's health conditions, since the increased life expectancy does not necessarily coincide with the expected number of healthy years. Figure 5 presents a subjective evaluation of individual's health. The data indicates a general trend of increases in self-reported health among all $55^{+}$individuals ${ }^{4}$. It is interesting to observe that this share is visibly higher for men for both age groups 55-64 and 6574. The younger age group reports slightly better self-reported health, but for men both age groups follow the same trend. In contrast to that, among women there are visible gaps in the early 1980 s and between the 1990s-2000s, which seem difficult to explain. 
Figure 5: Share of population that evaluates their health as 'Good' or 'Very good' Percent Men

Percent

Women

80

60

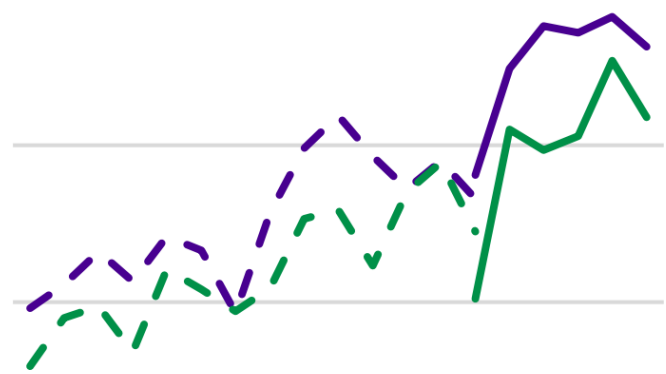

50

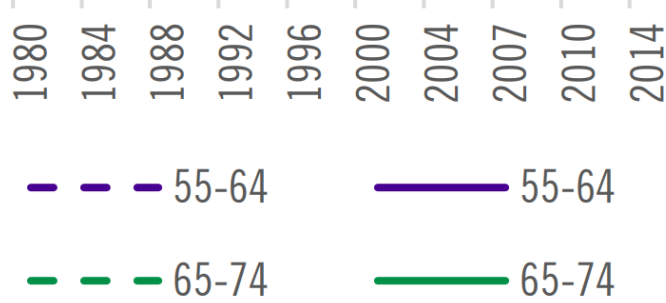

80

70

60

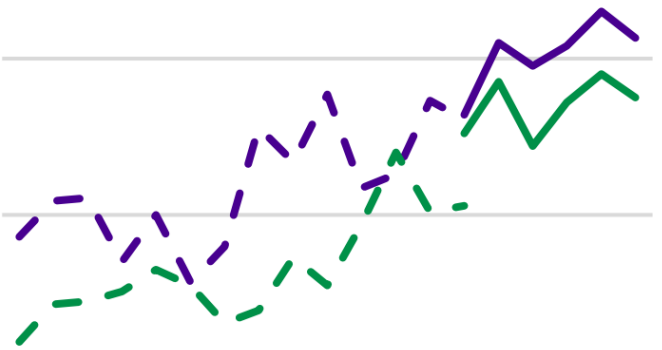

50
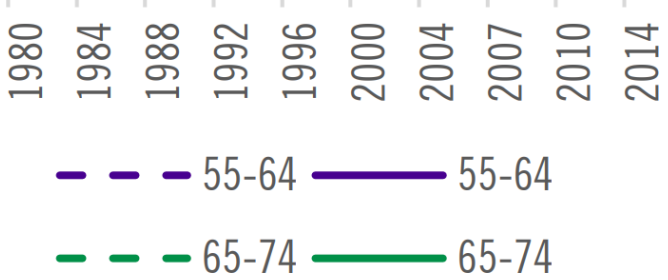

Source: ULF; Laun \& Palme, 2018, p.22.

Thus, based on life expectancy as well as increasing health and labour market participation rates, Laun and Palme (2018) present the indicator of the labour market capacity among various age groups. It shows the potential for labour market participation, in which anticipated participation rate for 65-74 year-olds is around $80 \%$. As it is seen in Figure 6 and Figure 7, the overall labour market participation capacity is high from the age of 65 years and onwards. But the differences between genders are clear once the age increases. According to the estimations, the capacity for additional female participation at the age group of 55-59 is only $1 \%$, while for male it is $5 \%$. Moreover, the overall participation rate is expected to be higher among the latter. This shows not only that female health has not improved at the same rate, but also that younger women have a high participation rate. The same cannot be said for the age group 65-74. Here female participation in the labour market is low and constitutes half or less of that of the men in the same age category. 
EXCLUSION AND INEQUALITY IN LATE WORKING LIFE

WORKING PAPER 5:

EXCLUSION AND INEQUALITY IN LATE WORKING LIFE: NATIONAL COUNTRY

CONTEXT - SWEDEN

Figure 6: Share of labour market participation for men and estimated additional labour market participation capacity (grey colour)

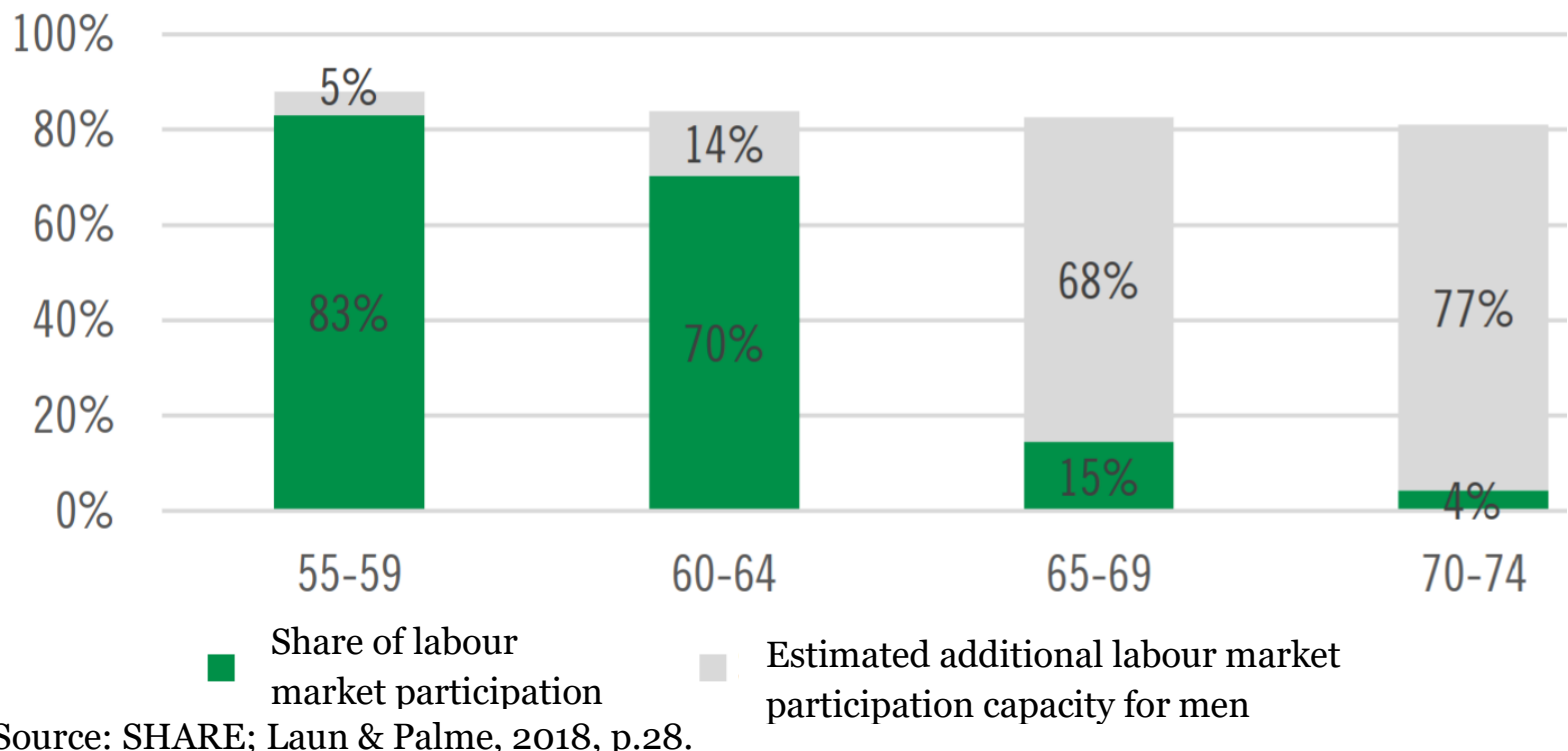

Source: SHARE; Laun \& Palme, 2018, p.28.

Figure 7: Share of labour market participation for women and estimated additional labour market participation capacity (grey colour)

\section{$100 \%$}

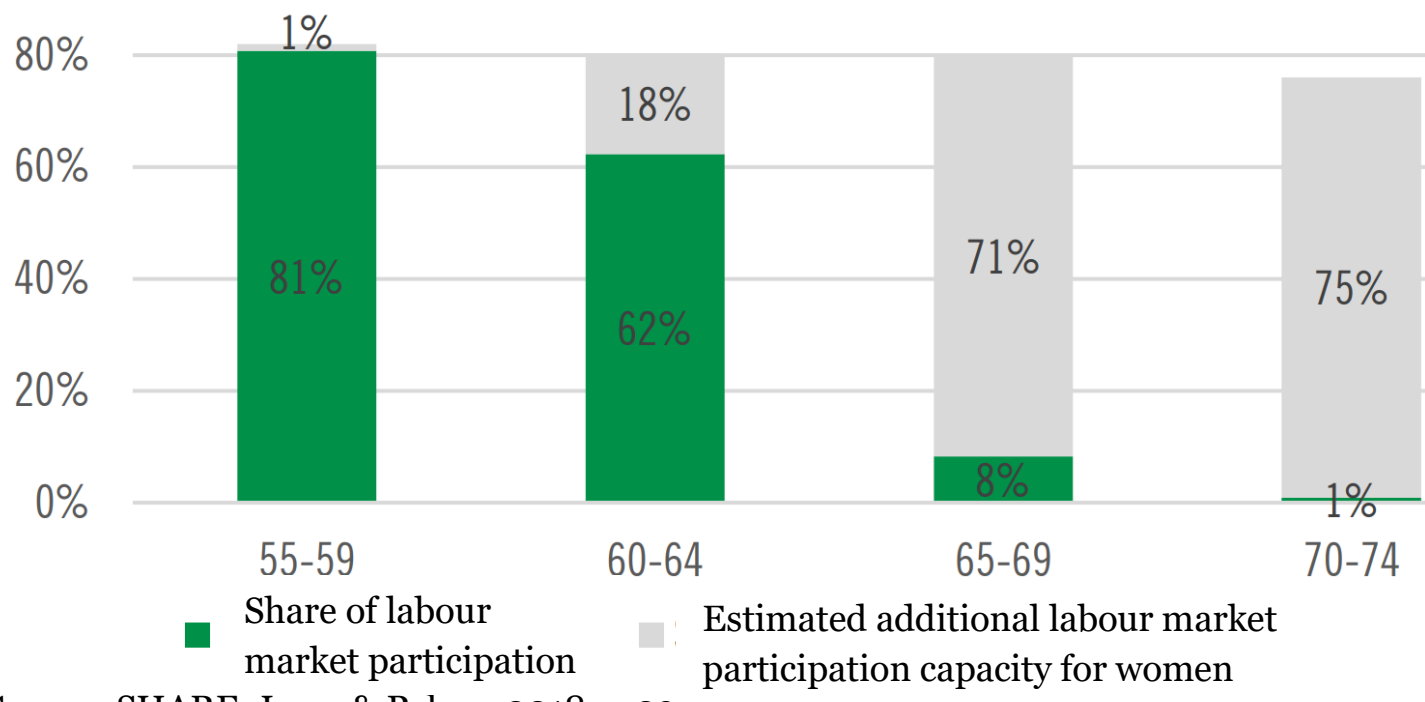

Source: SHARE; Laun \& Palme, 2018, p.29. 
EXCLUSION AND INEQUALITY IN LATE WORKING LIFE: NATIONAL COUNTRY

CONTEXT - SWEDEN

\subsubsection{Labour market participation patterns and characteristics: age and gender aspects}

Continuing the labour market participation topic, it is important to look at the unemployment trends. Both, Figure 8 and Figure 9 show a clear drop in unemployment around the 1990 ond then a sudden increase again, which could be seen as a direct effect of the economic crisis. The age group of 60-64 was more affected by these economic fluctuations. There were higher unemployment rates among age group 60-64 than age group 55-59 since the 1960s, but the gap has started closing since the late 2000s. 60-64 year-olds have seen the highest increase in labour market participation during the last decades, the reasons for this have been discussed in Chapter 1. The overall unemployment rates among men are on average around 2 percent higher than among women.

Figure 8: Unemployment among men 55-59 and 6o-64 years, 1963-2016

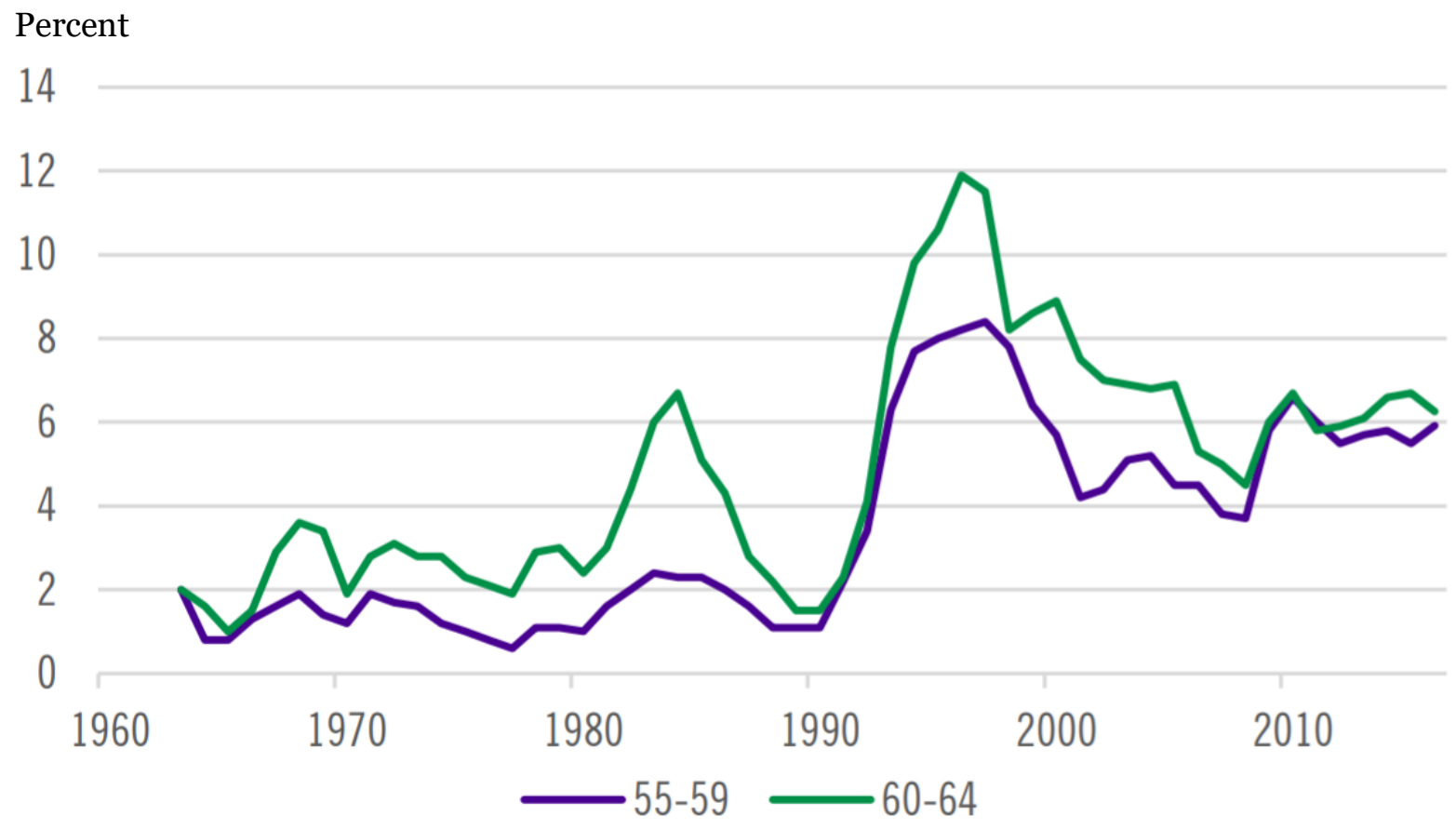

Source: AKU; Laun \& Palme, 2018, p.12. 
Figure 9: Unemployment among women 55-59 and 6o-64 years, 1963-2016

\section{Percent}

14

12

10

8

6

4

2

0

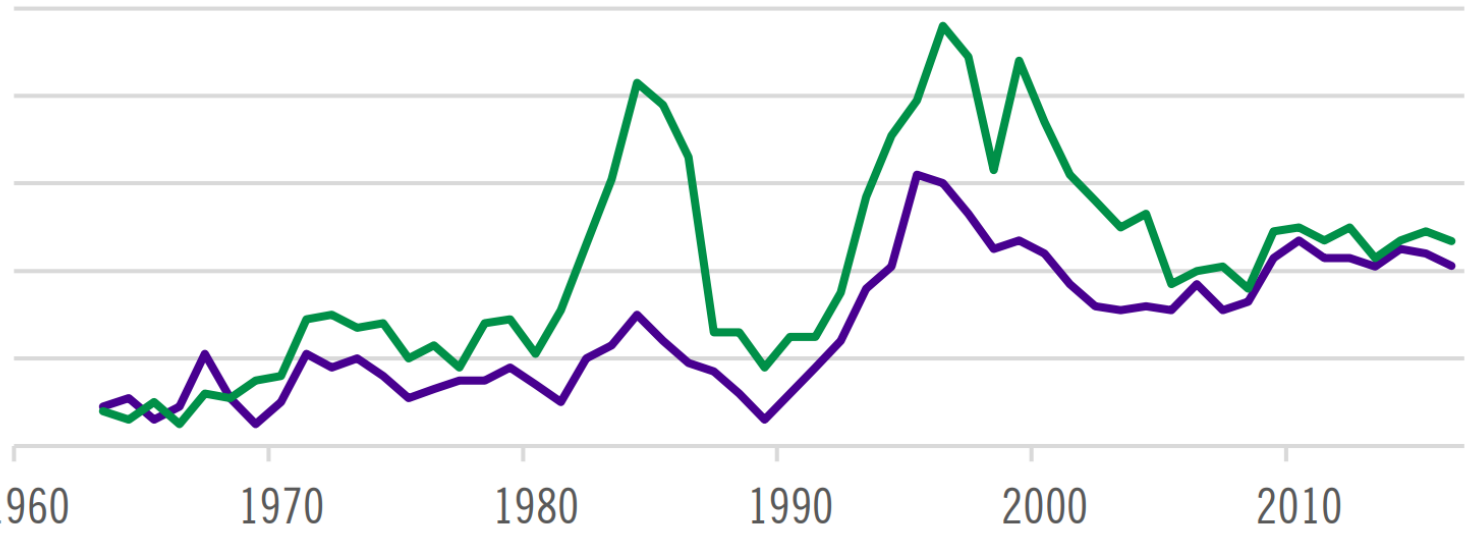

1960

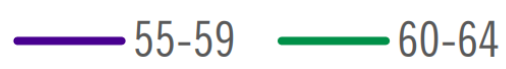

Source: AKU; Laun \& Palme, 2018, p.12.

On the other hand, older women on average work less hours than men every week (Appendix, Figure 23). Among 55-64 year-olds, this gap reduced during 1976 to 2006 from a gender difference of 10 hours to around 5 hours a week. Men were more stable over time, working 40 hours a week, while female working time increased from approximately 30 to 35 hours. In 2005, the reference group was redefined and now includes 55-74 year-olds, thus the comparison to the previous years is not possible. Nevertheless, similar trends of around 5 hours gap in working time can be observed among men and women. However, the average working time for men is reduced to just above 30 hours and women work slightly more than 25 weekly hours, as from 2005 onwards people up to the age of 74 (and not only 64) are included in the calculation of the weekly average (Laun \& Palme, 2018).

The overall labour market participation decreases gradually between $55-65$ from around $80 \%$ to $20 \%$ for men and 10\% for women for all the cohorts (1935-1950). Yet, with every later cohort, individuals work slightly longer (Appendix, Figure 24). 
EXCLUSION AND INEQUALITY IN LATE WORKING LIFE: NATIONAL COUNTRY

CONTEXT - SWEDEN

\subsubsection{Labour market participation patterns and characteristics: types of employment, sectors and working conditions}

After considering the more general aspects of health and gender in late working life, we now turn to specific characteristics, such as sectors and branches as well as types of employment and working conditions.

The data presented in Figure 10 represents a shorter time span and indicates that among the 65-74 year-olds, the majority is employed in the private sector. This held true throughout the years 2008 to 2013, except for 2013, when there were slightly more 65-69 year-olds working in the governmental sector. In general, there was a big increase in the number of 65-74 year-olds participating in the labour market - from 81000 in 2008 to 140000 in 2019. The number was growing the fastest in the municipal and regional sectors (from 12000 to 38 ooo), while the governmental sector has demonstrated a more moderate growth (from 4000 to 9 ooo) (SOU, 2020:69).

Figure 10: Share of labour market participation in state, municipal/regional and private sectors among 65-74 year-olds, \% in 2008, 2013 and 2018.

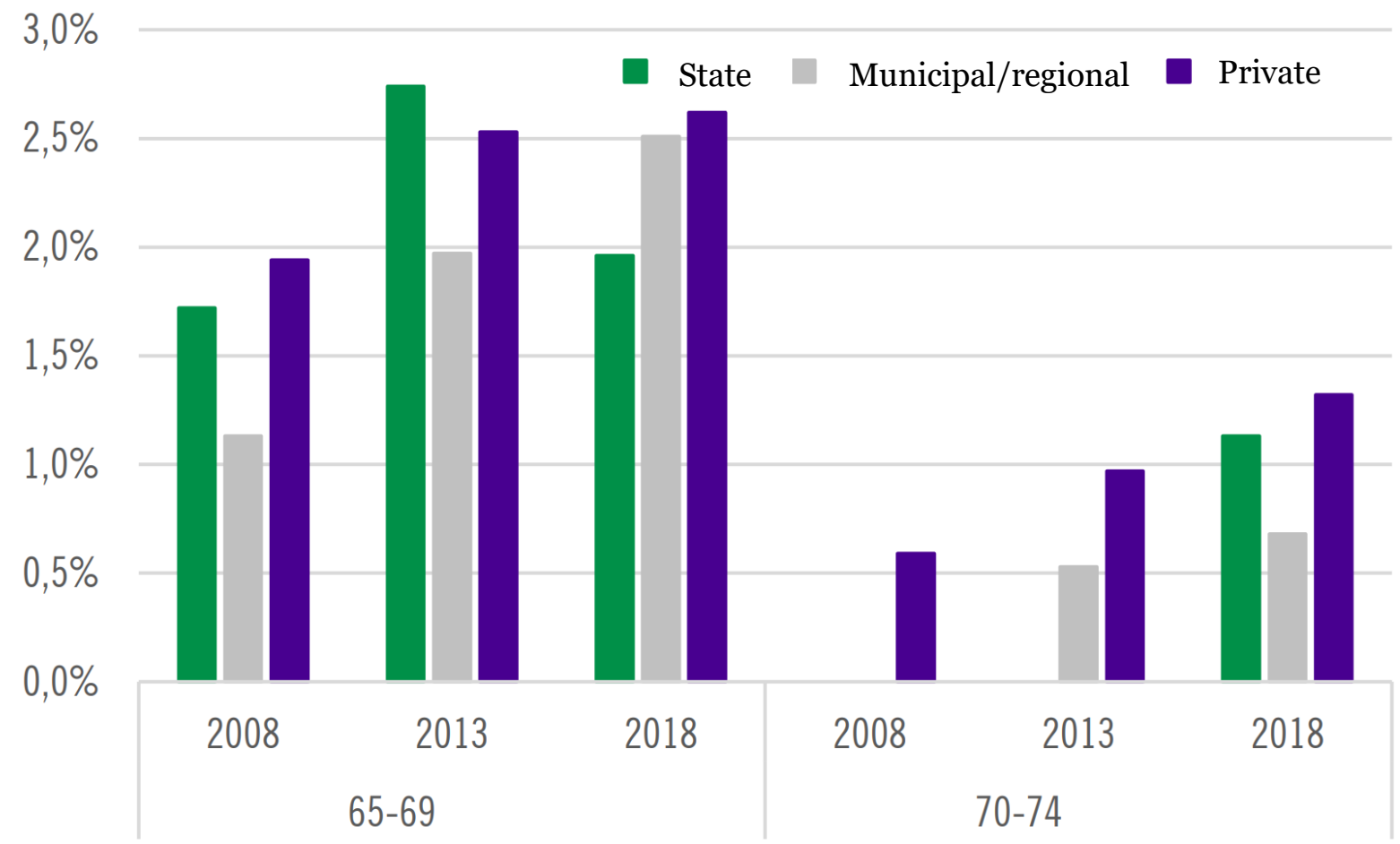

Source: SCB, AKU; SOU, 2020:69, p.89. 
The fastest growth in labour market participation for age group 65-74 during 2005 to 2018 was among white-collar workers, with $65-69$ year-olds being at the forefront, while the participation among blue-collar workers was growing more moderately (Figure 11). Here some gender differences are visible. The share of women among both white- and blue-collar workers in age group 65-69 has quadrupled, while for men it doubled. This massive increase was also observed among 70-74 year-olds, where in comparison to 2008, in 2018, there was a $100 \%$ increase in the share of blue-collar workers and a 400\% rise among white-collar workers (SOU, 2020:69).

Figure 11: Labour market participation by occupational status (white- and bluecollar workers), thousands, 2005-2018

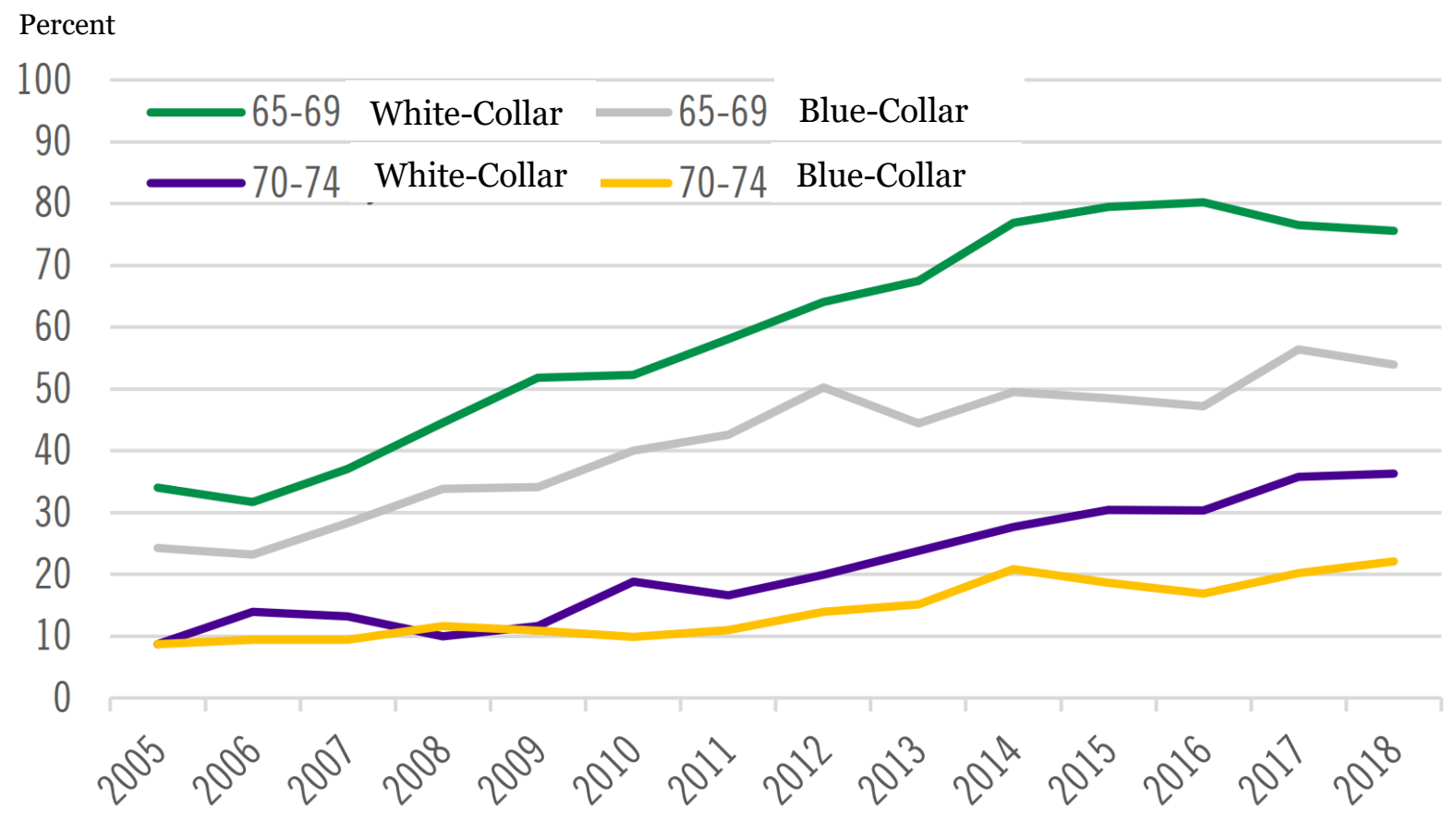

Source: SCB, AKU; Fransson \& Söderberg, 2019, p. 11.

The majority of all 65-74 year-olds work in financial and business services. It is especially common among 70-74 year-olds $-26 \%$ of the employed individuals work in this branch (SOU, 2020:69). This branch covers a variety of employer types and one interesting aspect in this branch are the temporary working agencies (bemanningsföretag). The temporary working agency (TWA) does not create an employment but mediates between employers and potential employees. These are staffing companies, which hire individuals and then later 'rent' them to other companies. TWAs are widely spread in the Swedish labour market and are often used as an entry to the labour market by young people and migrant workers. Lately, 
these agencies have turned to the older work force and there is an expansion observed amongst TWAs profiling themselves as the ones offering senior labour. The types of jobs covered by TWAs vary from manual labour to highly skilled specialists and the jobs in these agencies span from carpenters or plumbers to IT specialists and nurses. Work at the TWAs is further characterised by atypical, shortterm temporary contracts and lower payment. It is difficult to estimate, what share of the 65 to 74 year-olds work in the TWAs and what jobs they carry out. The branch of financial and business services also includes the self-employed who provide direct services for other businesses (see below for more on this type of employment).

Another common branch for employment in this age group are health and care jobs, followed by jobs in education. The numbers employed in these sectors were rising during 2005 to 2018 (SOU, 2020:69). Women of all age groups are overrepresented in the welfare sector jobs, where work is both physically and mentally demanding (Arbetsmiljöverket, 2018) as well as often characterised as more atypical with short term and less secure contracts (SCB, 2020). The latest working environment statistics show that women work with other people (e.g. customers, clients, patients) to a higher degree than men. They have also less control over their work and do more mentally demanding jobs (Arbetsmiljöverket, 2018). Less control over work tasks was in general more common among young (until 30 years) and older workers (50 to 64 years) (SCB, 2020). The data indicates that the majority of women (15-74 year-old) in 2009 to 2017 were employed in health and care sectors as well as education. In comparison to men, about five times more women were working in the health and care sector and around 3 times more women were employed in the education sector (Figure 25 in Appendix). These sectors are traditionally female dominated among all the age groups.

In 2019, the highest number of temporary employed in the whole population were working in the health and care sector as well as in education. In the former, temporary employment was 3 times more common for men compared to women. Women also constitute a higher share in substitute (vikariat) positions and are more likely to have zero hour/on demand and hourly contracts (behov-och timmanställning). In contrast to that, there were more men in probation and project-related employments. Temporary employment is more common among lower educated people and the share of those having temporary employment rose from $20 \%$ to $38 \%$ between 2005 and 2019 . Half of the temporary employed are also employed on a part-time basis (SCB, 2020). Lower education might be linked to the labour market positions on the secondary, lower-skilled labour market, which is often characterised by more precarious work and atypical employments. 
Figure 12: Share of temporary employed among all employed individuals in 2019 Percent

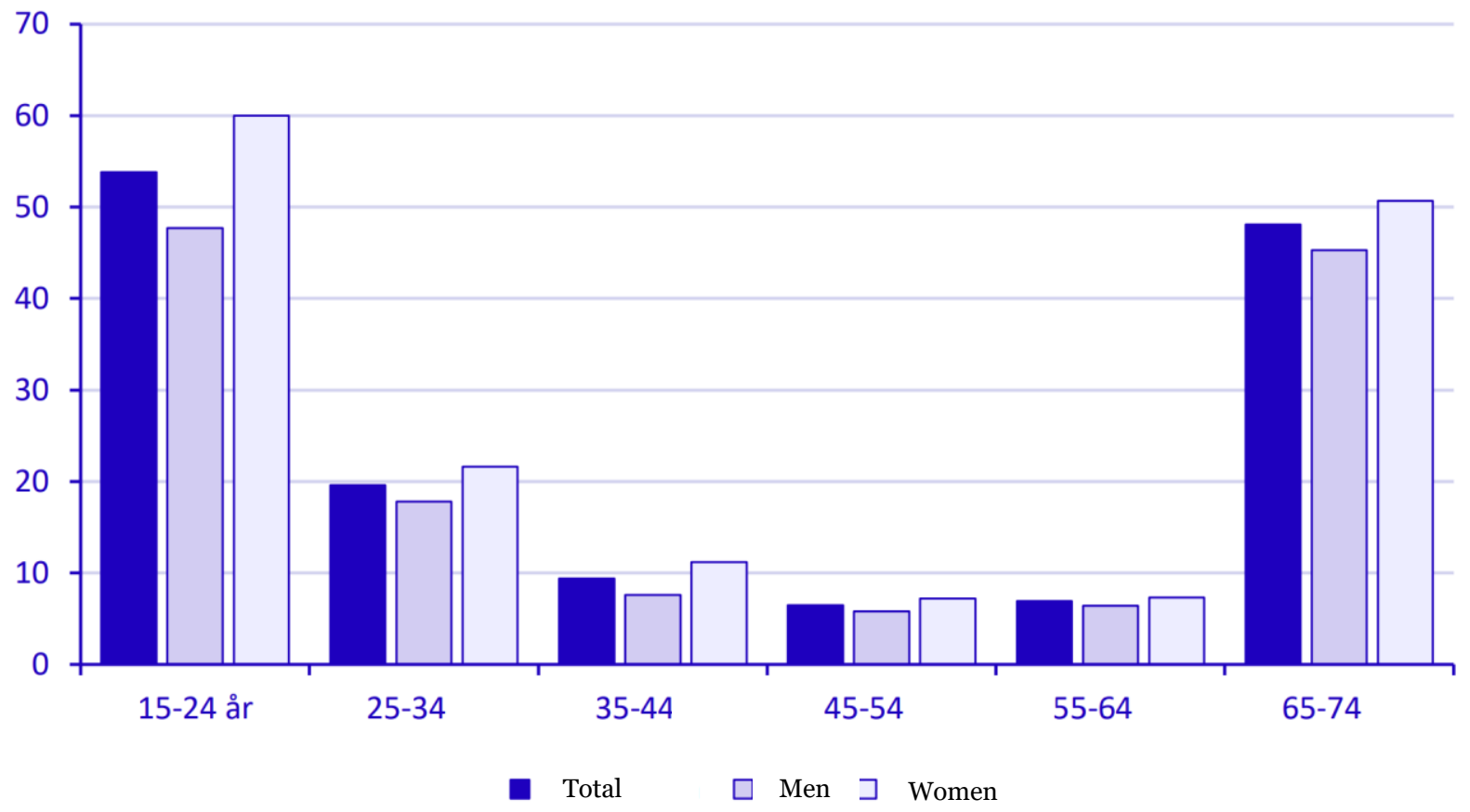

Source: SCB, 2020, p. 10.

Temporary employment rates were also rising among older people. In $200539 \%$ in the age group 65-74 were temporarily employed. Except for the economic crisis, temporary employment rose steadily to $48 \%$ in 2019 , constituting almost half of the employed individuals at this point. The employment rate in this group rose from $10 \%$ to $18 \%$ during the same period (SCB, 2020). This can be related to the increasing number of employed in this group, who primarily work in the financial and business services (which also include TWAs), health and care as well as education sectors. The two latter sectors were already mentioned above as having a tendency towards temporary employments. Further, they are female dominated and having in mind that the labour market participation increased more among older women than men and grew fastest in the municipal/regional sector (where these jobs are often located), one can expect this rise to be linked to gendered employment trajectories. Compared to other age groups, less than 10\% aged 45-54 and 55-64 have temporary employments. In terms of gender, around 5 percentage points more women work on a temporary contract than men (SCB, 2020). This can be related to the discussion in Chapter 2, where temporary employments among women are discussed in connection to the higher share of care obligations during female life courses and especially in the older age, which leads to changes towards 
part-time and temporary employments to keep the working arrangements more flexible and compatible with care responsibilities. The interruption in working life due to care obligations can also accumulate and translate to less attachment to the labour market in terms of more atypical employments and temporary working contracts (Szebehely, 2014; Wall, 2014). The highest share of temporary employed older workers (65-74) has a high school degree or higher education. More than half of all temporary employed would like to have a permanent contract. The number corresponds to those aged 55-64 (around 60\%) but only less than 10\% of the 65-74 year-olds are interested in the permanent employment (SCB, 2020). That might indicate that temporary employment is seen as a source of flexibility, which is not necessarily involuntary.

Temporary work is also connected to part-time work - a flexibility that many older workers prefer to have. Around 60\% of the 65-69 year-olds in the labour market work part-time. Both, short part-time (1-19 hours a week) and long parttime (20-34 hours). In the age group 70-74, around 80\% work part-time and about two thirds of those work 1-19 hours a week. Among 20-59 year-olds, only 10\% have a short part-time work, while $25 \%$ work long part-time and almost $70 \%$ work fulltime (SOU, 2020:69). The average working time per week has mainly remained unchanged for the age groups 20-59, and 60-64 with slightly higher fluctuations for 65-69 year-olds and biggest changes for 70-74 year-olds. For the latter, the working time decreased during 2005-2018 (Figure 13). Considering the gender differences, in the age group 65-69, men work on average around 3.5 hours more per week than women and in the age group 70-74 this difference makes up almost 7 hours per week. White-collar workers are on average working less hours than blue-collar workers, which can be explained by the fact that the former are often more likely to adjust their working tasks more flexibly and work shorter hours. The total amount of hours worked among the 65-74 year-olds was rising under 2005 to 2018, which contributed to around 2.2 million work hours per week or an increase by $120 \%$. This relates to the demographic changes. The number of older people in the population is increasing as well as the labour market participation among this group. However, it does not go along with longer working hours worked by older individuals as mentioned above (SOU, 2020: 69). 
Figure 13: Average working hours per week for various age groups, 2005-2018

Working hours

per week

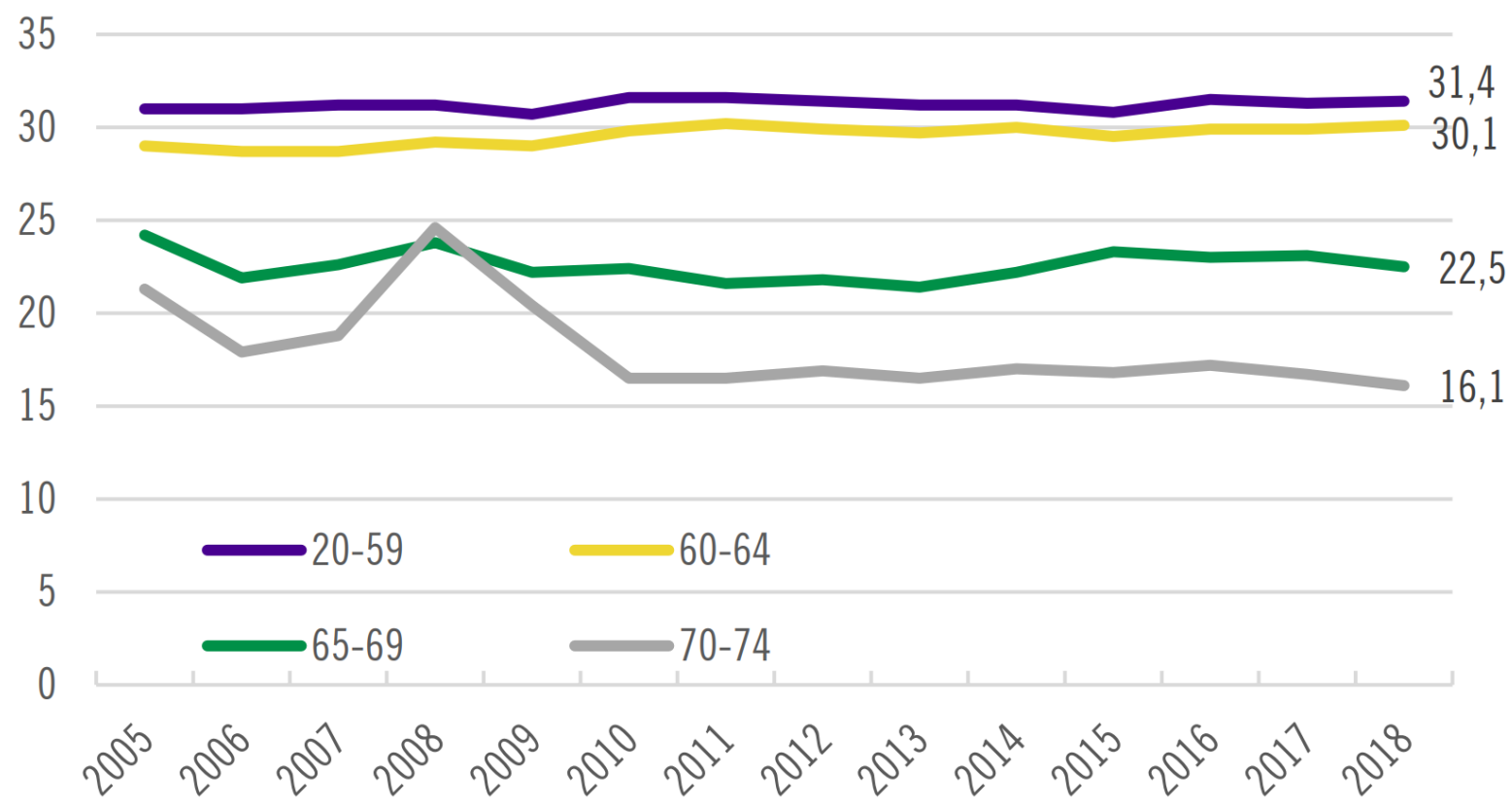

Source: SCB, AKU; Fransson \& Söderberg, 2019, p. 20.

In terms of ethnicity, there were more temporary employed among the ones born outside of Sweden. The share was rising from $21 \%$ in 2005 to $25 \%$ in 2019. It can be explained by the fact that many individuals born abroad have entry jobs in the Swedish labour market, which often begin with a probation period or another form of temporary employment. The highest temporary employment share was among women born outside Sweden - it amounted for $27 \%$ in 2019. Both women and men born outside Sweden had a 10 percentage points higher share of temporary employment compared to the ones born in Sweden. Furthermore, a higher share of foreign-born people were willing to get permanent contracts (around 70\%) in comparison to Swedish-born (slightly above 50\%). Moreover foreign-born people are more likely to move to unemployment after a temporary contract than Swedishborn people. It is important to mention that the biggest drop in temporary employment in relation to the economic crisis of 2008 was among foreign-born men (SCB, 2020; Figure 28 in Appendix).

In the total population, there are slightly more women working on temporary contracts than men, but there are more men who are self-employed or helping household members (doing unpaid labour that later benefits them via shared household resources) in a private business (Figure 27 in Appendix). 
Self-employment is very common among the older workers - out of more than 250 ooo of all employed in the age group 65-74 around one third were selfemployed in 2017 and a small share combine both employment and selfemployment. Self-employment, same as for the whole population, is more common among men than women. Around $40 \%$ of men and $30 \%$ of women are selfemployed or combine employment with self-employment (Figure 14). A big share of those self-employed in the age group 65-74 had their companies before they turned 65 , so this age, serves as a transition from employment to self-employment.

Figure 14: Labour market participation by the type of employment (employees, self-employed and combination), 65-74 year-olds, thousands in 2017

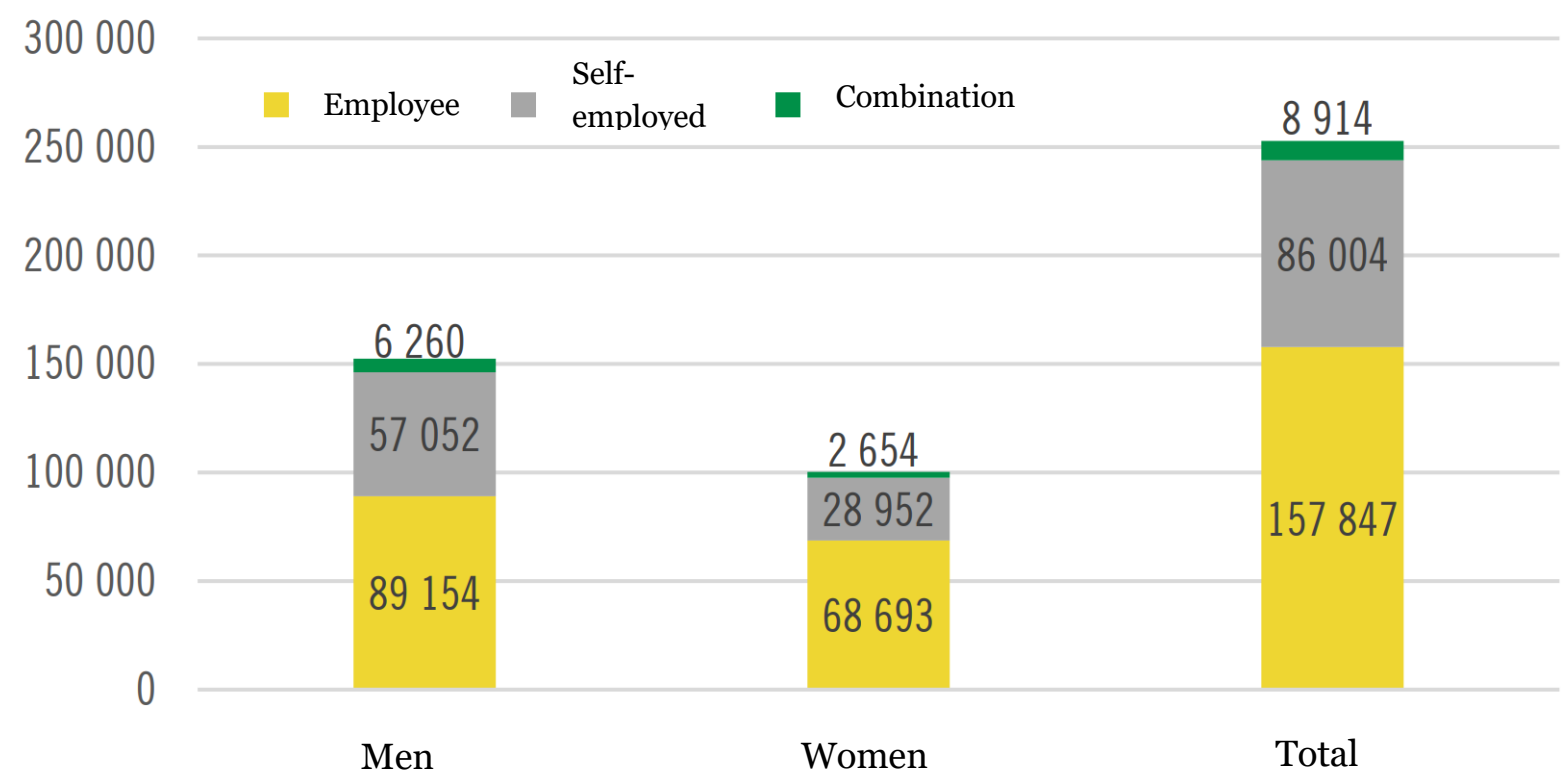

Source: SCB, Yrkesregistret; Fransson \& Söderberg, 2019, p. 16.

Turning to the working environment and conditions among older workers, there are no big changes towards the end of working life. Older workers are mainly content with their work where they can learn new things. They also express a will to have more control over their work tasks, pace and planning as well as would like to receive more help from their closest manager. The psychologically and physically demanding tasks are more often reported in age group 55-59 than 65-74, the differences between 55-59 and 60-64 are small. On the one hand, this can be related to the trend that the youngest workers (16-29) are most likely to have physically difficult tasks. On another hand, it can be tied to the so called 'healthy worker effect', which means that individuals in more disadvantaged health situations have already exited the labour market and do not work after the age of 65 (SOU, 2020: 
69). This goes in line with the data presented later in this chapter, which shows that labour market exit via health insurance takes place at the younger ages.

Around $7 \%$ among the 50-64 year-olds report difficulties to carry out their working tasks due to their age. This holds true for both genders but differs for those with high and low income. In 2009 to 2017 the trend remained stable, where around $4 \%$ of high earners and $9 \%$ of low earners reported difficulties. Slightly more than $10 \%$ of the working population indicates that they will not be able to work until common pension age. The female share was higher in all years between 2009 and 2017. According to the latest available data, from 2017, around $14 \%$ of women and $11 \%$ of men report that they will not be able to work until pension age (Arbetsmiljöverket, 2018). This can be tied to low-income earners and women having more disadvantageous and less sustainable working conditions. They are faced with difficulties to carry out current tasks and feel 'worn down' by strenuous tasks, which leads to an earlier retirement. On the other hand, the data presented in the beginning of this chapter reveals that women self-report their health lower compared to men, which can also contribute to the experienced difficulties in the labour market.

Besides the differences and inequalities in the labour market participation based on wealth, age and gender, education also plays a role in forming chances on the labour market.

\subsection{Education and lifelong learning}

Education is divided into formal education, non-formal education, and informal learning. The first type is taking place in public institutions, while the second is often provided by employers as staff training during working time or is gained during free time but upgrades work-related skills (Landell, 2016; SCB, 2018b).

The formal education level among older people has been growing for the last decades. Almost half of the women and men born in 1952 have high school education as their highest attainment in comparison to $25 \%$ of women and around $30 \%$ of men born 1923. The rate of people with higher education has also been rising - comparing cohorts 1923 and 1952, the level among women went up from $7 \%$ to $35 \%$ and among men from $10 \%$ to around $30 \%$. These increases correspond to the decrease in the share of individuals having lower than high school education. Comparing men born in 1923 and 1952, the share without a high-school degree decreased from around $60 \%$ to $25 \%$. The decrease was even more substantial among women - from $70 \%$ to around $20 \%$ (Laun \& Palme, 2018). These are positive developments since studies show that individuals with higher education tend to stay longer on the labour market. In fact, the highest share of early leavers is among women with lower than high school educational attainment (SOU, 2020:69).

In line with the rising educational attainment level, labour market requirements in terms of formal qualification level were also increasing between 1974 and 2010. 
Formal qualification levels were increasing more quickly for positions occupied by women compared to men. In 2010, the qualification requirements were higher for the jobs occupied by women compared to jobs occupied by men (SOU, 2020:69). The SCB report from 2018 indicates that the formally required qualification level was a big incentive for those with lower education attainment to participate in staff trainings, which led to receiving certificates, while other types of skills trainings in the workplace were more popular among people with higher education (SCB, 2018b).

More than half of the employed participated in education during their paid worktime between 2009 and 2017. Both women and men participated in education during paid worktime to a similar extent, however, women were participating slightly more. Considering all women who participated, less older women (50-64 years) than younger women (16-29 and 30-49 years) gained education during their paid time (SCB, 2018b). 5

Figure 15: Share of employed people who have gained education on their paid work time during the last 12 months, 2009-2017

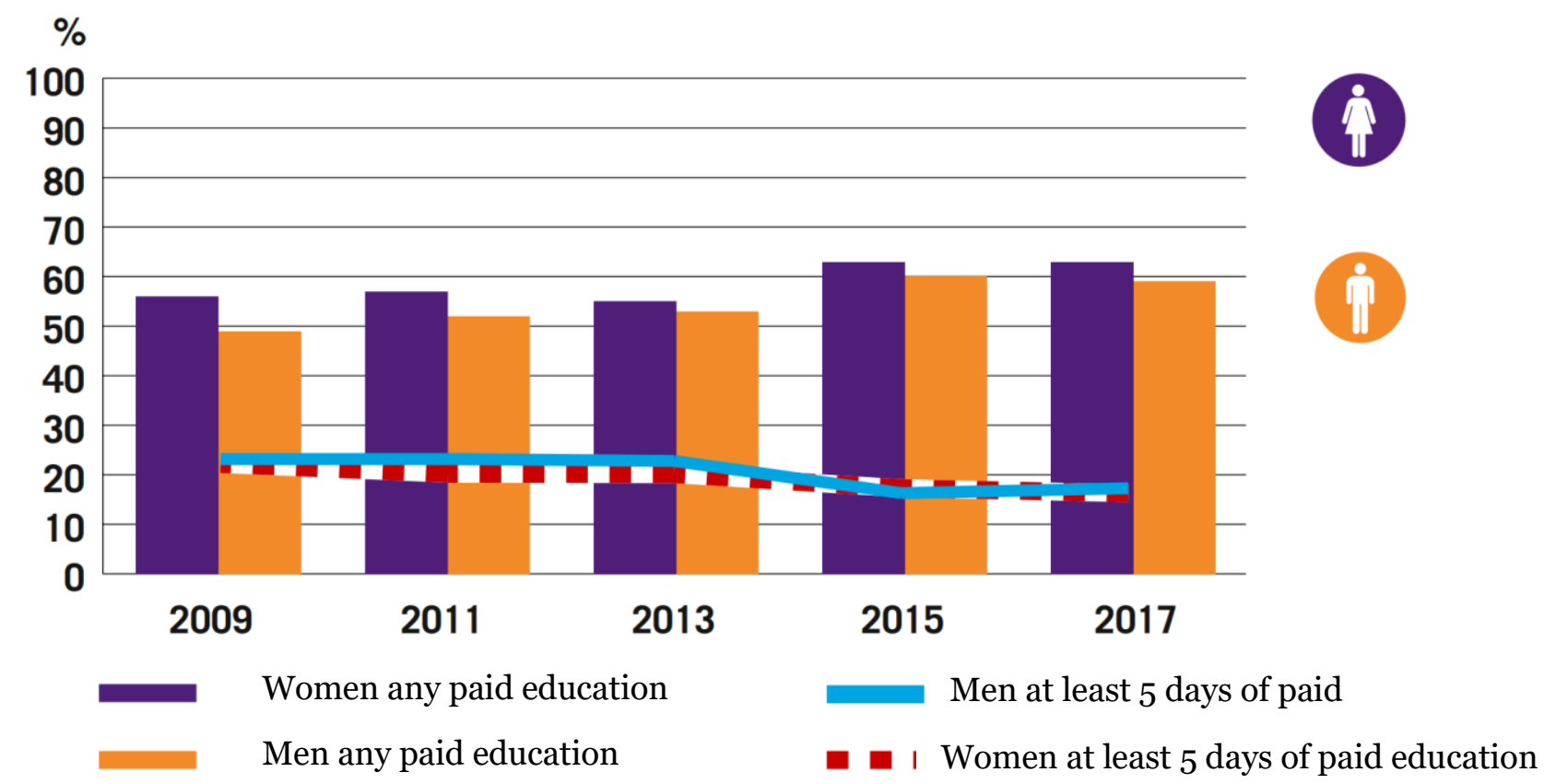

Source: Swedish national labour force survey; Arbetsmiljöverket, 2018, p. 28. 
The participation in education during paid work time was around 10 percentage points lower among older people (age $55^{+}$). Thus, it is interesting to investigate the motivation of those not participating in education. In comparison to younger people, a higher share in the age group 55+ was not willing to participate in education. On the other hand, almost $10 \%$, a very similar share to younger groups, were willing to participate (SCB, 2018b). Previous studies found that willingness to participate in training programmes is e.g. depending on social and governmental expectations, with social expectations being the most powerful (Focacci \& Lam, 2020). This could potentially explain the low willingness for participation among the age group $55^{+}$, as there might be social expectations about education and development of older workers that could inhibit their willingness to participate in training programmes.

Figure 16: People, who did not participate in the education split by willingness to participate
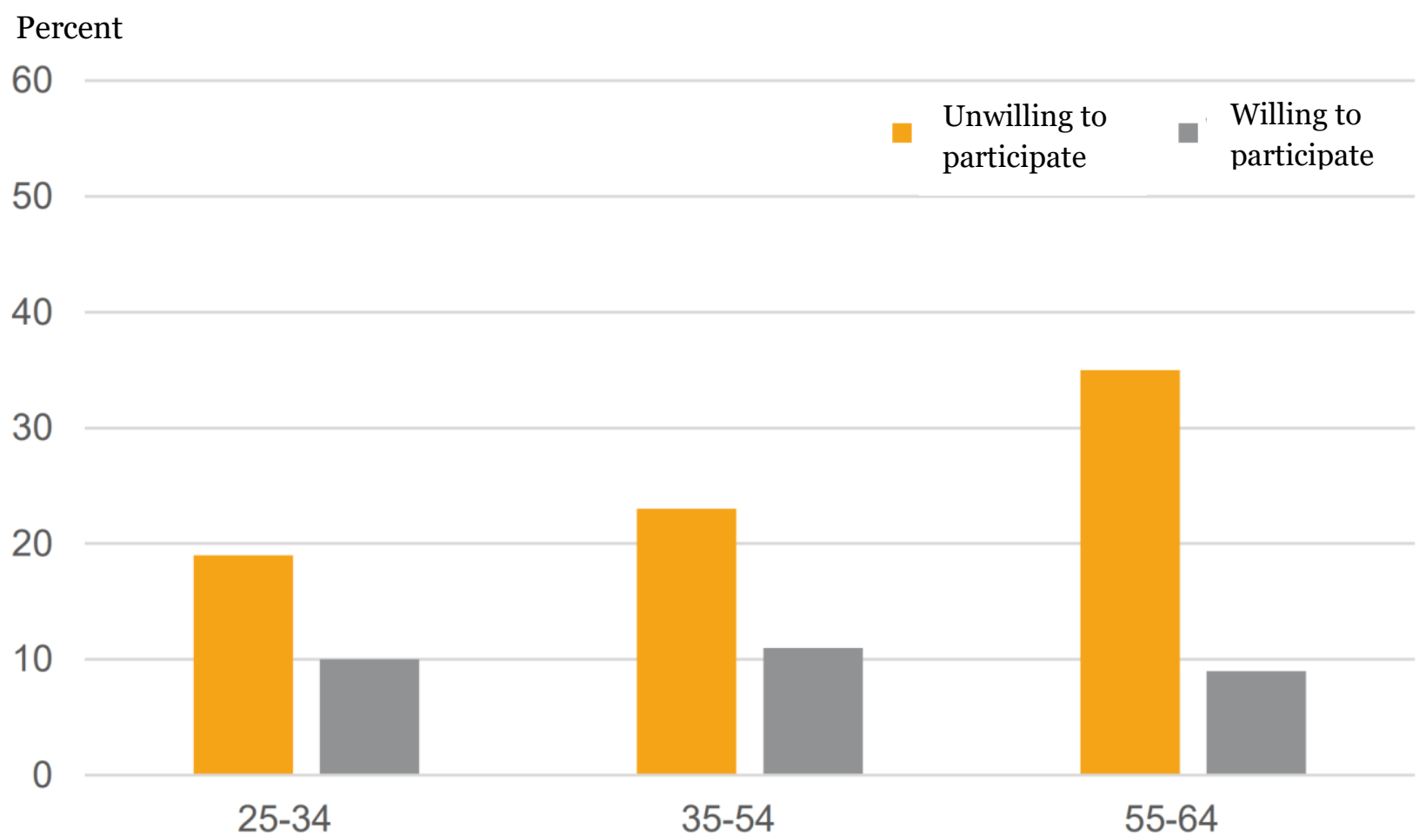

Source: AES 2016; SCB, 2018b, p. 85.

This indicates some temporary or more structural barriers for participation. People, who are close to the normative pension age are reported to have less access to education and training at the workplace and are involved less in new projects (SOU, 2020:69). This can, on the one hand, affect the productivity of older workers in the 
short term, prevent them from competing in the labour market and prolonging working life. On the other hand, these practices can be seen as ageist and received by older employees as a sign of exclusion from a workplace, a subtle message about the value of the employee or as encouragement to retire at a certain age (SOU, 2020:69).

\subsection{Labour market exit: patterns and characteristics}

There is no defined statutory pension age in Sweden, but a rather strong normative understanding about a pensionable age as well as some age barriers in various security systems, which serve as a natural transition to the pension system at the age of 65. The flexibility in the pension system is very high and the pension can be taken out fully or partially by choosing one of the pension parts or combining them. This is possible also due to the Swedish pension system, where various parts of pension come from different sources - state, occupational funds, and possibly private savings. Moreover, even full pension from various sources can be taken out together with the income from work (full- or part-time). As it was discussed above, many reduce weekly working hours or change type of employment at an older age instead of directly going from full-time employment to full retirement (SOU, 2020:69; see also Chapter 4). This makes it more difficult to define the age at which people retire. Therefore, a few indicators are used to monitor different aspects of the labour market-retirement transition. Average retirement age (medelpensioneringsålder) shows an average age when individuals start to take the main state pension. It did not change much between 2005 and 2019 and is 64.6 years. Even though the state pension takeout is very flexible and can be done partially, most individuals take the full amount or half of it. There is also a small share of individuals, who start taking out this pension, then pause it and later resume (SOU, 2020:69).

Figure 17 and Figure 18 show what share of individuals take a state pension for various cohorts and at which age. The developments reveal interesting dynamics. A 65 -year norm is not set in stone and instead of starting to take out pensions later, a larger share take it earlier, between 61 to 64 years. The trend looks similar for men and women, just in the 1938 cohort there were around $10 \%$ more women taking the pension at the age of 65 and in contrast to more men taking pension both before and after 65. In the 1953 cohort, around $45 \%$ of the women started taking the pension at the age of 65 and 35\% started taking out pension earlier (at age 61-64). The changes in taking pension out at 66 years were more moderate and rose from $10 \%$ to $20 \%$ between cohorts 1938 to 1951 . For the male cohort 1953, the gap between the share taking pension at the age of 65 and the age of 61 to 64 is even smaller.

There are slightly more men than women who take out an early pension, which can be explained by more women than men getting income from health insurance 
EXCLUSION AND INEQUALITY IN LATE WORKING LIFE

WORKING PAPER 5:

EXCLUSION AND INEQUALITY IN LATE WORKING LIFE: NATIONAL COUNTRY

CONTEXT - SWEDEN

and more women working part-time or having lower salaries (SOU, 2020:69). In that case, taking out pension before the age 65 would mean an even lower pension in the future, since the pension system in Sweden rewards a takeout of the state pension from the age of 65 (see Chapter 4).

Figure 17: Share of newly granted state pensions for various cohorts, women

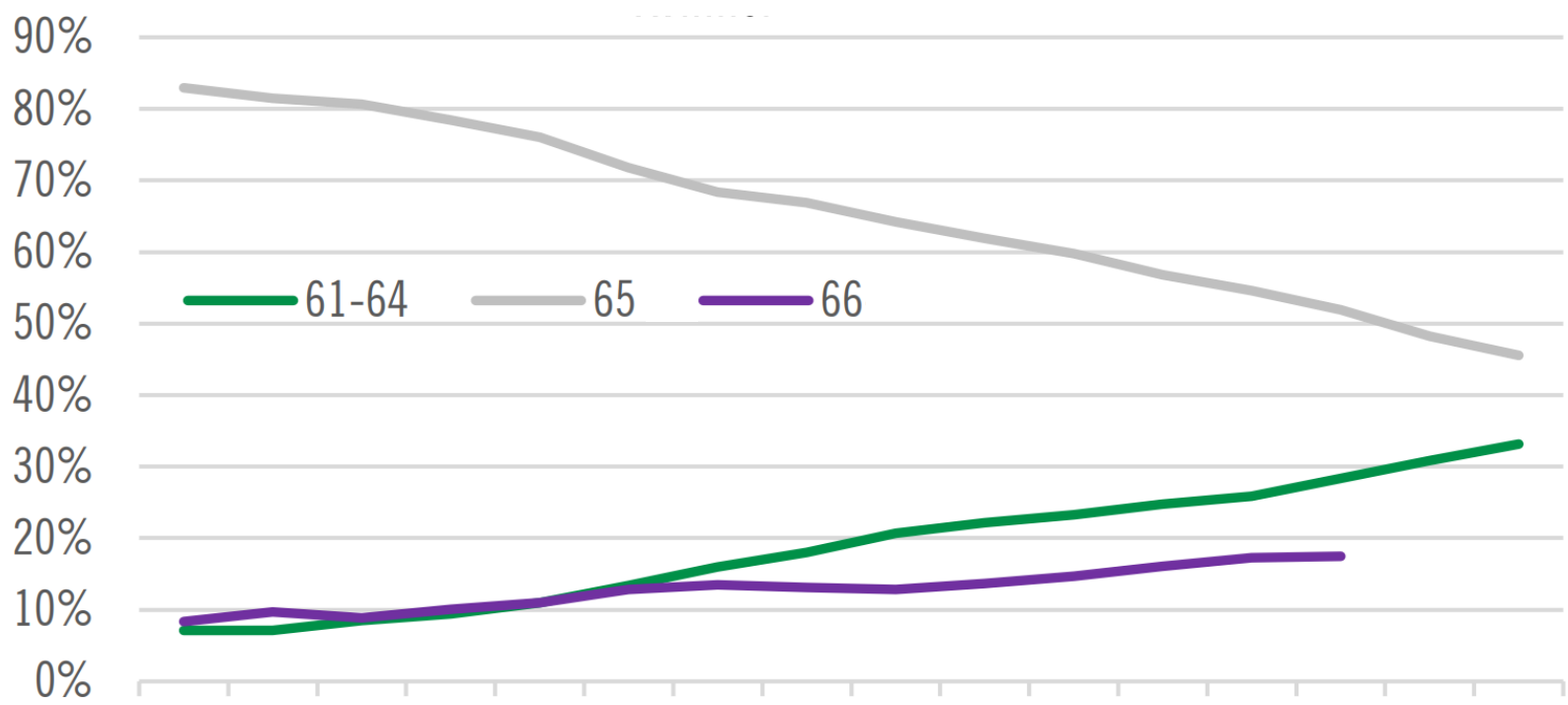

1938193919401941194219431944194519461947194819491950195119521953

Source: Pensionsmyndigheten; SOU, 2020:69, p. 100.

Figure 18: Share of newly granted state pensions for various cohorts, men

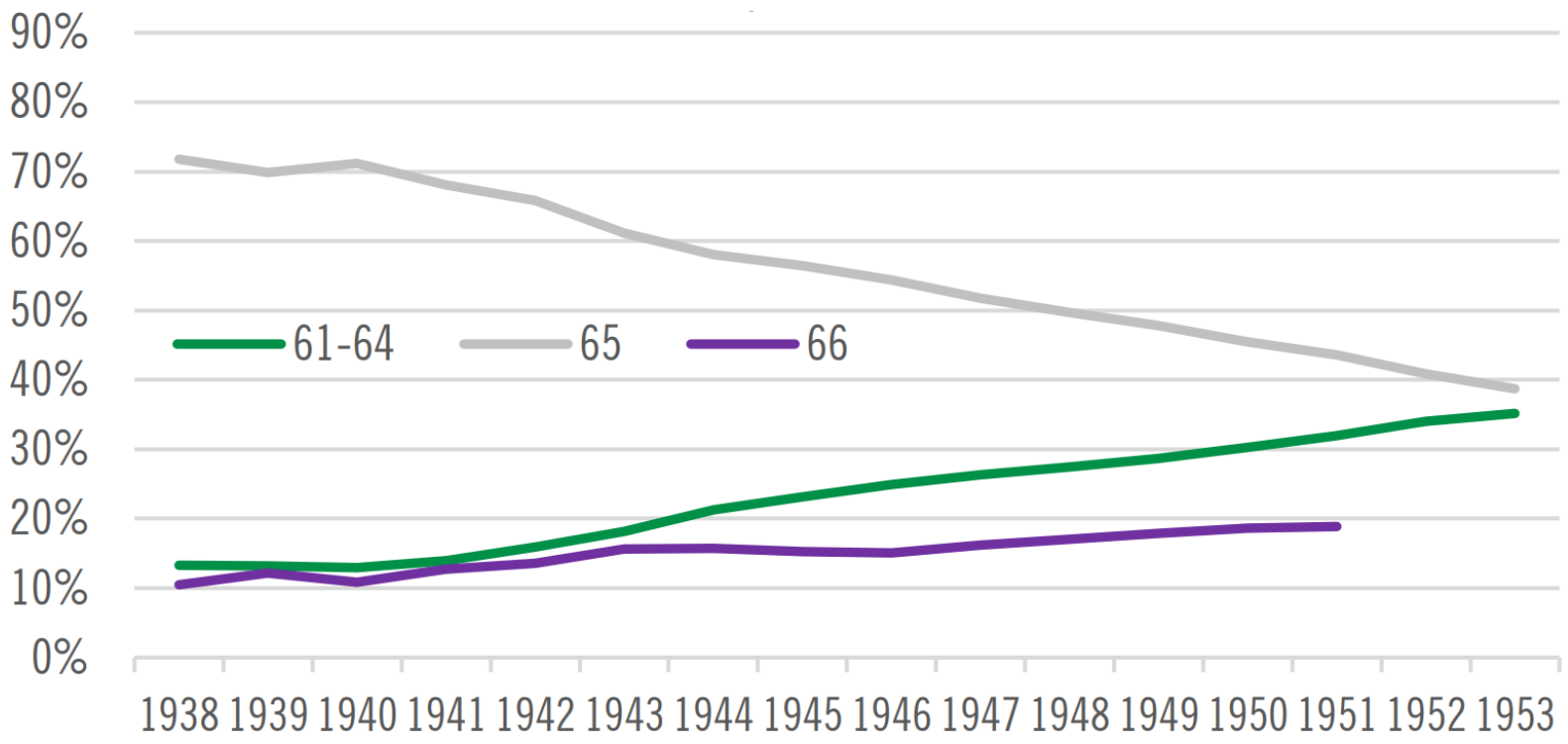

Source: Pensionsmyndigheten; SOU, 2020:69, p. 100. 
The trends clearly indicate an increase in taking pensions earlier. During 2003 to 2009, the share was growing fastest among 61-63 year-olds and later flattened out, but continued to increase steadily, especially among 63 year-olds. Almost one third of the ones taking pension before the age of 65 were 63 years old. Over $15 \%$ were 62 years old and less than $10 \%$ aged 61 . Some people taking the state pension earlier also combine it with income from the labour market. The share of 61-63 year-olds, who combine their pension with income from the labour market, was rising between 2003 to 2006 and the curve has flattened during 2007 to 2016. In 2016, around half 61-year olds combined the income from both pension and work. Slightly less of the 62 year-olds and around $40 \%$ of the 63 year-olds combine work with pension. The tendency to work is reducing with increasing age, thus gradually less individuals combine income and pension later in life. One of the main reasons for taking an earlier pension and combining it with income from work is because the latter is low. The income usually starts reducing a few years before individuals start taking out the state pension, which indicates that they participate in the labour market only part-time or have even exited it. With the reducing income from the labour market, the income from the state, occupational and private pension is increasing. Also, the share of income from unemployment and health benefits increases. Some take out their pension earlier and invest it or save money for themselves (SOU, 2020:69).

If around 50\% of the 61 year-olds combine the income from state pension and work, almost the same share (45\%), who take this pension did not have any income from labour market since a year before. The distribution of the income sources also signals about the living standard as well as inclusion in the labour market. Those, who combine work and pension income have higher disposable income and better health as well as a better labour market situation. This reveals inequalities in the late labour market based on health. The inequalities also depend on the level of education - as was mentioned earlier, highly educated people tend to stay in the labour market after the age of 65 . There is a slightly higher number of low educated people, who take pension at the age of 61. Couples tend to take an earlier pension than singles, because the combined income is an advantage. On the other hand, when an age difference between partners exists, early pension take out becomes more likely, especially among the often younger female partner to spend retirement together with their older partner (SOU, 2020:69).

In addition to measuring when individuals take out their pension, another indicator, labour market exit (utträde från arbetsmarknaden), is widely used for labour market-retirement transition analysis. The labour market exit is measured as the age when the main annual income from the labour market in a given year and the two following years is lower than a certain base (in 2019 the base for the annual income was 46500 SEK). This age does not have to coincide with the average age of the pensions take out, but the two are related (Laun \& Palme, 2018).

As can be seen in Figure 19 and Figure 20, the peak of exiting labour market for all the cohorts is around 65 years, though, there is a bigger share of women who exit 
EXCLUSION AND INEQUALITY IN LATE WORKING LIFE

WORKING PAPER 5:

EXCLUSION AND INEQUALITY IN LATE WORKING LIFE: NATIONAL COUNTRY CONTEXT - SWEDEN

labour market at the age of 65 or earlier in comparison to men. The exit after 65 years is more even among the genders, though men overall exit later.

Figure 19: Share of men exiting the labour market, by age and birth cohort

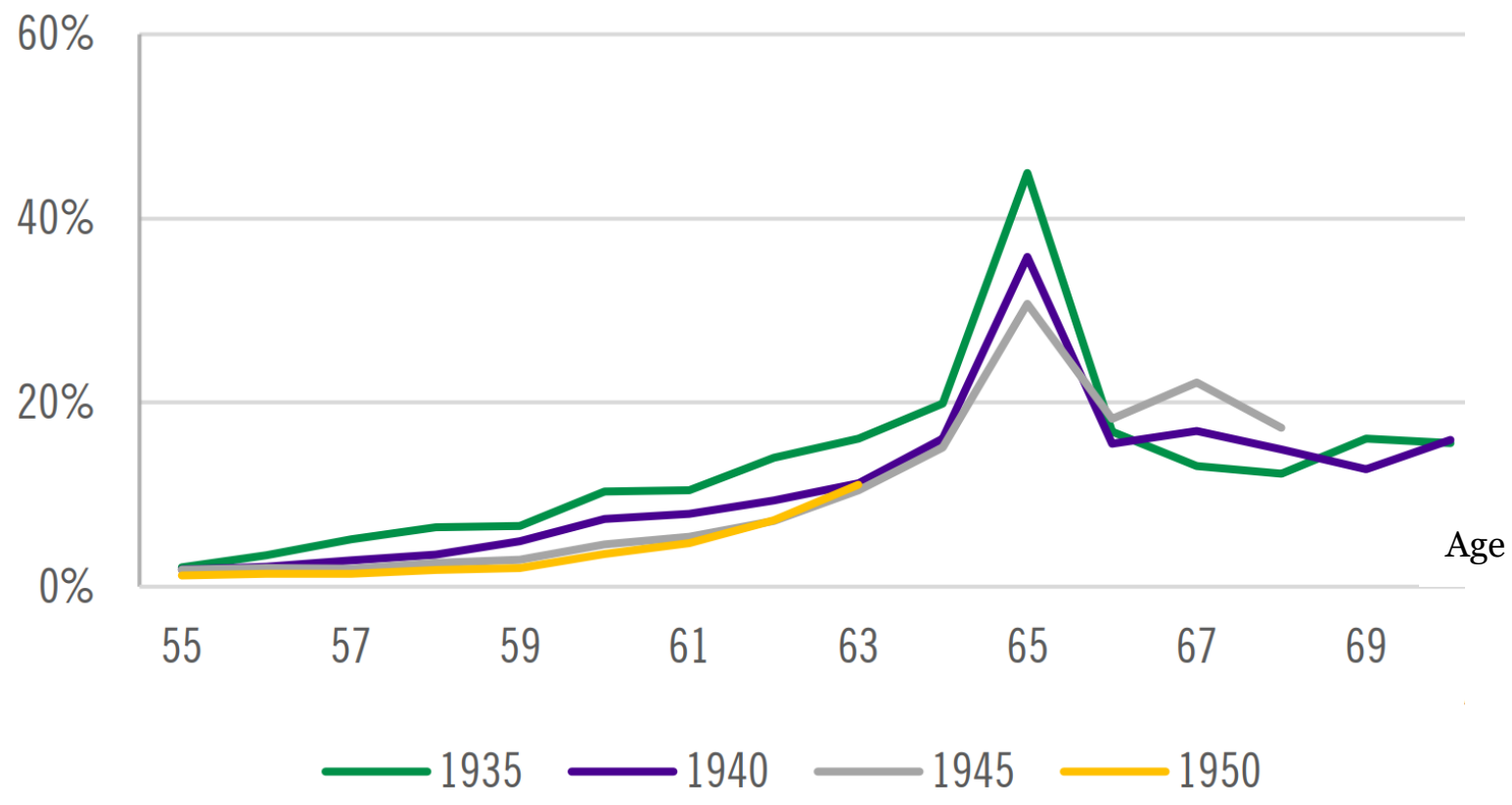

Source: LOUISE-database; Laun \& Palme, 2018, p. 15.

Figure 20: Share of women exiting the labour market (by age and birth cohort)

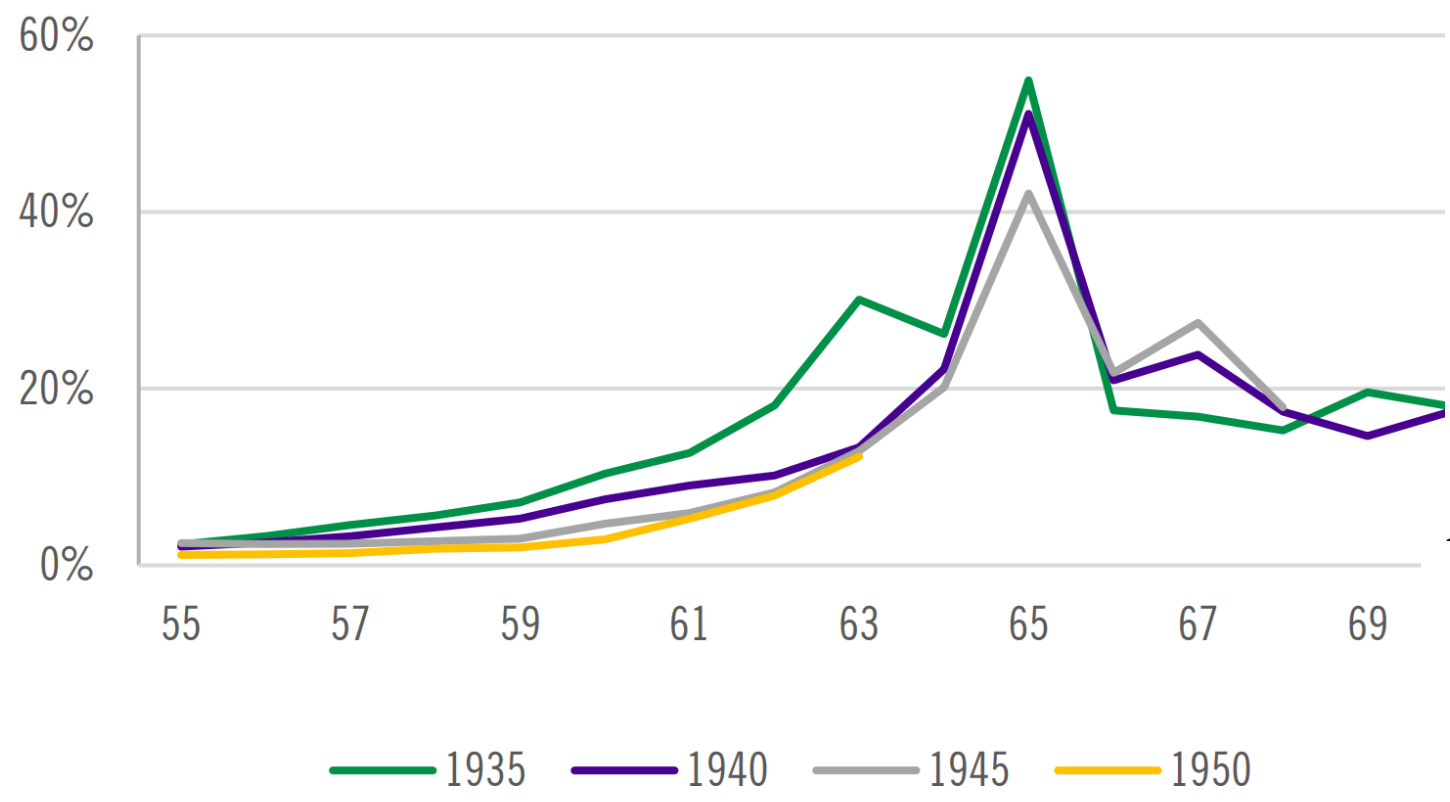

Source: LOUISE-database; Laun \& Palme, 2018, p. 16. 
Among the ones, who take out the state pension early and exit the labour market, many see a drop in disposable income already a year before. This is a consequence of the dependency on income from health insurance or unemployment benefits (SOU, 2020:69). Analysing the path of exiting the labour market, Laun and Palme (2018) define a pension path and a social insurance path. The former encompasses state and occupational pensions and the latter health insurance (sickness and disability benefits) and unemployment benefit.

In all cohorts, there is a slightly higher percentage of women who exit the labour market via social insurance path (sickness/disability benefits or unemployment benefits) and higher percentage of men exiting via the pension path. More women than men, who leave via the social insurance way, leave via disability benefit (14\% and $7 \%$ ). There are more men, who leave via unemployment benefits in comparison to women (accordingly, 12\% and 17\% during 2010-2016) (SOU, 2020:69). From the available data presented above, this could be explained by a combination of lacking access to the labour market among women and their lower (self-reported) health in comparison to men. For both genders, the exit by the social insurance pathway on average means much earlier exit - between 59 to 60 years. While the pension path is usually taken from 63 years onwards (Figure 21 and Figure 22).

Figure 21: The average age of exiting the labour market by age and the pension and social insurance path

Men

Age

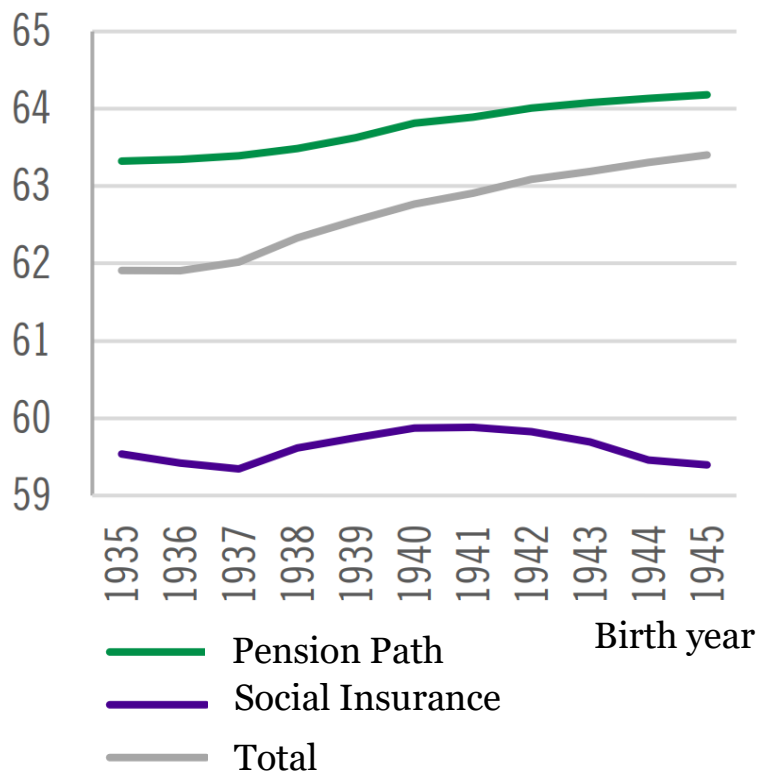

Women

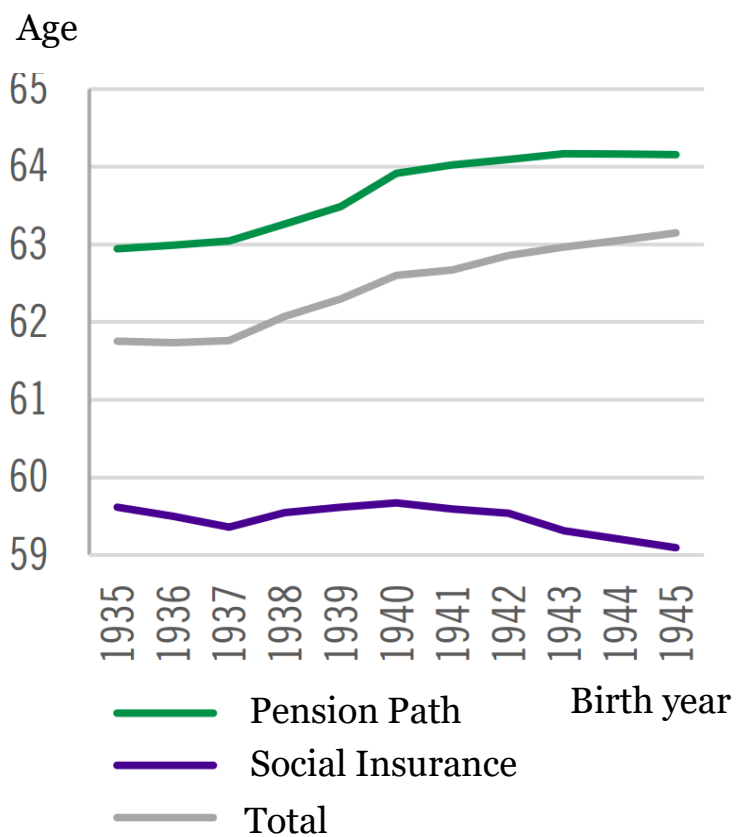

Source: LOUISE-database; Laun \& Palme, 2018, p. 17. 
There is a relation between year of birth and the share of the older individuals exiting the labour market. Before the amendments in the disability insurance system, it was possible to exit via receiving these benefits due to labour market reasons, which made this a particular way known as an 'early retirement' benefit. It was especially common among people with low education and low income, probably because of the worse health and labour conditions among this group (SOU, 2020:69). Abolishing this rule and instead basing eligibility for disability benefits only on health conditions, dramatically reduced the number of receivers (see also Chapter 4). This trend is visible in Figure 22, where the drop in the exit via the social insurance path is almost identically mirrored in the rise of the exit via the pension path. This also affected the age when older people leave the labour market, since the exit via social insurance was mostly common for the ones younger than 6o. Occupational pension is usually taken for the first time between 60 and 64 years and state pension are more commonly taken out at the age of 65 .

Figure 22: Share of the people exiting the labour market by year of birth and the pension or social insurance path

Men

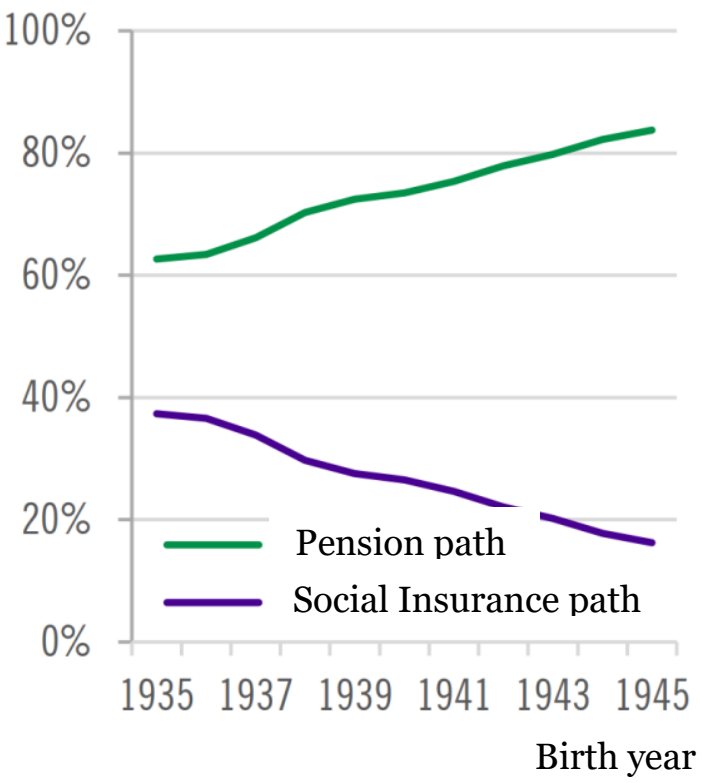

Women

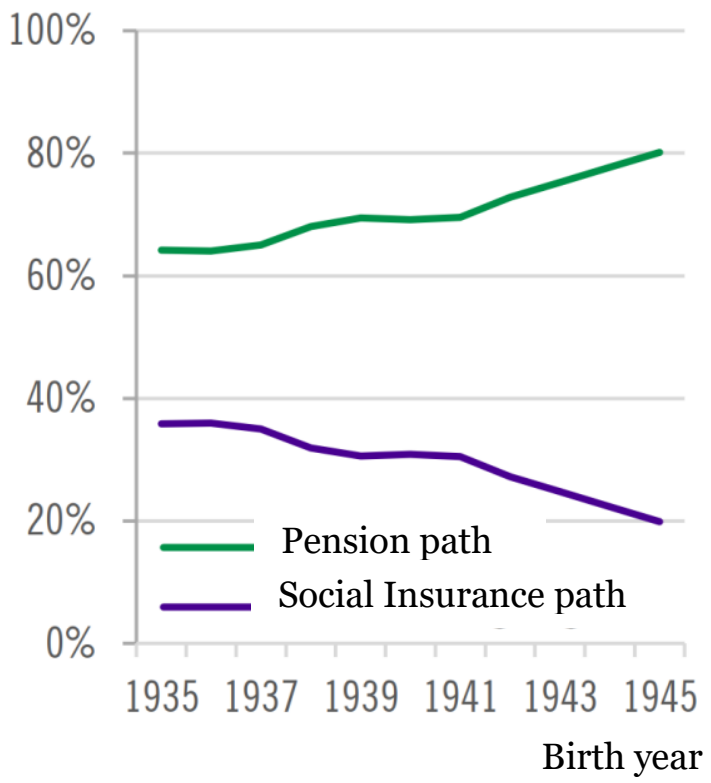

Source: LOUISE-database; Laun \& Palme, 2018, p. 18.

Labour market exit is unequal among various groups. It depends on laws and regulations, workplace, and individual factors. Laws and regulations have various age criteria, which often form the circumstances for a labour market exit. Among 
the ones who take out an early pension, one finds both, privileged and disadvantaged groups. For instance, a variety of state employments still allow to exit the labour market at the age of 61 and here using an occupational pension is the most common path. Early leavers from the municipality and regional sectors more often take health or sickness benefits. The workplace is also important as it is related to specific sectoral characteristics and work environment. On average, women from female dominated sectors such as health and care sectors as well as education leave the labour market later than the rest of the women. For both, men and women, the highest likelihood to take an early pension is related to physically hard work, which more often has lower educational requirements and is more common in the sectors dominated by men - forestry workers, agriculture workers or postal service employees. On the contrary, the lowest share of early pensioneers is in the occupations, which require a higher education, such as psychologists, health and care specialists or university and college teachers. The physically hard work is more likely to lead to workplace accidents, but a stressful work environment, lack of inclusion in the group or even mobbing can as much contribute to 'worn down' employees and their low wellbeing - both are factors that can contribute to early exit from the labour market. Not the least important are employer's attitudes towards older workers, ageism and age discrimination in the working place (SOU, 2020:69).

The decision to take pension depends on many factors and these often work in combination with each other. Research shows that the decision to keep on working beyond the age of 65 depends on inequalities in individual circumstances. Health condition, education and economic situation play a big role here. Women report that their own and their relatives' health affect their decision to take out their pension. Further, women more often than men state that their economic situation does not allow them to take an earlier pension (SOU, 2020:69).

To conclude, since demography is changing, the age group between 65 and 74 years is growing. In parallel with this, labour market participation is increasing in the same age group. However, late working life and labour market exit are not the same for everyone and depend on different factors. Firstly, there are gender differences. Women aged 55 to 74 rate their health lower than men and consequently women also leave the labour market more often through disability or sickness benefits. Women are also more likely than men to work in a form of temporary employment, which is less secure and usually less paid than permanent contracts. In contrast to that, men are more likely to work as self-employed, which offers great flexibility in late working life. The highest share of early leavers from the labour market are women, especially low-educated women. Education is another factor in late working life and labour market exit. Higher educated people are more likely to have permanent contracts and stay longer in the labour market compared to less educated people. This goes along with the trend that white-collar workers (usually higher educated) tend to work longer than blue-collar workers (usually less 
educated). An explanation for this could be that white collar workers often have more flexible working conditions, so that they can change their working conditions to their needs, as they grow older. Furthermore, blue-collar work tends to be more physically demanding and can therefore lead to earlier exits. Another factor impacting late working life and labour market exit is ethnicity. People born in another country are more likely to be temporary employed and are more likely to be unemployed after the end of a temporary contract.

\section{$4 \quad$ The most influential policies regarding late working life profile}

Late working life in Sweden is shaped by various policies that partly constitute who and when to enter and exit the labour market. One of the main legislations that delineate the normative boundaries for the labour market exit is the old-age pension system. The other is the Labour Protection Act. As early retirement became increasingly popular a few decades ago, recent policies seek to prolong working life to safeguard welfare financing. Therefore, not only the pension system itself needed modification, but also the health insurance system and labour protection legislation. Changes are made not only in institutions and legislations, but also within companies by adapting HR strategies. Different measures are taken to protect the rights of older workers, counteract ageism and incentivise companies to employee older workers.

\subsection{Retirement and pensions}

The old-age pension system in its current form encompasses income pension, premium pension and guarantee pension as well as occupational pension. The national public pension (income and premium pension) is income-based (also called, a main pension) and depends on the earnings throughout the working life. The income pension is tax funded (first pillar, PAYG) and the premium pension is accumulated in the private funds. The guarantee pension is a benefit, based on residency in Sweden and is paid to those having low income-based pension or to those not entitled to it. Occupational pension forms the second pillar, provided via the employer and is an important addition for those who have high earnings. Lastly, the third pillar of the private pension savings is also available in Sweden. The first and second pillars of the pension as well as the occupational pension can have a flexible take-out age and it is possible to take a partial $(25 \%, 50 \%, 75 \%)$ or a whole pension in combination with income from work, though a minimum age thresholds exist. The minimum age (for both genders) for the income-based pension is 62 years 
(since 2020), but the take-out age is flexible, and the guarantee pension can be accessed from 65 years onwards (Ministry of Health and Social Affairs, 2016).

The Swedish pension system underwent several changes since its introduction in 1913. Pension age was reduced and then raised again. More recent changes in the pension system from the 1990 s and early 2000 s seek to integrate older people into the working life and foster late working life participation.

As of 1 January 2020, the minimum pension age was raised from 61 to 62 years. The guarantee pension age will be raised from 65 to 66 in 2023. Moreover, from 2026 onwards the pension age will be tied to the average life expectancy. This means that the person who takes pension before a certain age (66 in 2026), will have a lower compensation rate (Pensionsmyndigheten, 2020b). For instance, if a person takes a pension at the age of 65 , the compensation rate will be $59 \%$, if at 66 , the rate will rise to $62 \%$. It is important to mention that women have on average lower compensation rates than men, so they would need to work longer than men to receive an equivalent pension. For the foreign-born people, who on average have even lower compensation rates, this would mean even longer working lives than for Swedish-born women (SOU, 2020:69). Considering only the national public pension, the foreign-born people living in segregated areas on average receive approximately $73-77 \%$ of the pension level of the Swedish-born. Foreign-born people, who do not live in segregated areas receive on average $82-85 \%$ of the pension of the Swedish-born. The pension gap increases even more when occupational pensions are taken into consideration - foreign-born people receive on average $64-72 \%$ of the pension of Swedish-born people. To tighten this gap, the retirement for the foreign-born people would need to be prolonged to 70-73 years, if the Swedish-born retire at the age of 65 (FTF, 2018).

The retirement in Sweden is very flexible and aims at dispersing ages for the pension take-out. This means more individualized retirement decisions, which are often difficult to take due to the complexity of the pension system. Despite the retirement age(s) being postponed, other age-related barriers exist in various security systems, which sustain a norm of retirement at 65 years, but has unequal effects for various groups. For instance, a combination of the guarantee pension and housing supplement (bostadstillägg) being available from the age of 65 makes it more beneficial for low-income earners to take their pension at this age. Another important constituent here is the occupational pension. It is often a decisive component in the pension system, which defines the higher and lower pension receivers and lifts many to a more decent rate. Occupational pensions in Sweden are higher for men compared to women (due to the reason that men are more likely to have a higher income) and higher for blue-collar workers compared to white-collar workers (Bergold, 2020). The size of and access to it depends on the individual's occupation and collective agreement. For example, certain agreements, especially in the state sector, allow a take-out of occupational pension as early as age 55. Most of the occupational pensions stop contributions when a person turns 65 , even if one 
continues working after this age. The payment of the occupational pension in some cases starts automatically from age 65 unless one actively expresses a will to not receive it then. Occupational pension is also sometimes automatically paid out within five years and a payment extended over a longer period needs to be applied for. That causes common misjudgement about the pension size and encourages to retire at the age of 65 (SOU, 2020:69). If workers are not covered in a collective agreement or a more informal special employment contract, they often do not receive any occupational pension (FTF, 2018). It is estimated that around $95 \%$ of the Swedish-born workers are covered, while only around $89 \%$ of foreign-born women and $86 \%$ of foreign-born men are covered by these agreements (FTF, 2018).

\subsection{Health insurance: sickness, rehabilitation and disability insurance}

Every employed person has a right to sick pay (sjuklön) for 14 days. After that, the Swedish Insurance Agency (Försäkringskassan) provides a sickness benefit (sjukpenning). The sick pay is tied to the employment regardless of one's age, but a sickness benefit is usually paid until one turns 65. Afterwards, if an employee is taking more than 180 days of the benefit, an individual evaluation is carried out and the benefit might be stopped. After the age of 70 , the maximum of available duration for the sick benefit is 180 days (SOU, 2002:69).

When a person participates in a labour market-oriented rehabilitation with the aim to maintain or restore work capacity, one can receive a rehabilitation compensation, which can be paid out until one month before a person turns 65 . The same rules apply for the ones who got an occupational injury and receive a compensation, unless the injury was endured after the age of 65 , then compensation can only be paid until 67 years old (SOU, 2002:69). While no separate data is available on gender differences in claims for rehabilitation compensation, gender differences are observed when it comes to claiming sickness benefits including rehabilitation benefits. In 2017, women in all age groups made more use of these benefits compared to men. On average, women received 13.3 paid net days of sickness benefit and rehabilitation allowance in 2017, while men received 6.9 paid net days (SCB, 2018). This might be connected to the gender differences in selfreported health (see Chapter 3.1.1). In addition to gender differences, also income plays a role for older workers' health conditions. In 2009 to 2017, $9 \%$ of the loweducated people workers between 50-64 years had problems to execute their work tasks due to their age, compared to $4 \%$ of the high-educated workers in that age group (Arbetsmiljöverket, 2018). This might be related to the fact that blue-collar workers, who often work in more physically demanding and accident-prone work environments, are often less educated than white-collar workers.

The age limits connected to these benefits obviously mark the line, where a person should transit from the health care system to the pension system. 


\subsubsection{Disability benefit: activity and sickness compensations}

Another important policy is the disability benefit. Since the 1950s Disability Insurance has transformed from covering purely health related issues to being applied on eligibility-based on labour market issues or a combination of both. Thereby, Disability Insurance turned into an early retirement scheme. Special conditions for 60-64-year-old individuals applied that meant lower medical requirements, no demand to participate in education and rehabilitation as well as lower requirements to change place of residence or occupation. These special conditions were removed in 1997 and the eligibility due to labour market reasons was removed in 1991 (Karlström et al., 2008). Despite of that, this so called 'early retirement' (förtidspension) policy also worked as a labour market policy and allowed for people to retire at the age of 60 . This was done in combination with employers laying off staff at the age of 58.3 , who then later were eligible for 450 days of unemployment benefit before they could move to an early retirement scheme (Galte Schermer, 2020). The scheme increasingly expanded and was criticized for being expensive, thus it went under reforms between 2000 and 2003. In 2003, the 'early retirement' scheme was moved under the health insurance area and is now called disability benefit (sjukersättning och aktivitetsersättning). However, it still is often referred to as an 'early retirement' scheme (RiR, 2005:14).

There currently are two types of this insurance and the eligibility mainly depends on age. Individuals who are 19 to 29 years old and will not be able to work for one year or longer are mainly entitled to activity compensation in the event of sickness (aktivitetsersättning) and individuals between 30 to 64, who will likely never be able to work again, are eligible to sickness compensation in the event of sickness (sjukersättning). Even 19-29 year-olds can get the latter type of benefit, if they too are assumed to never be able to work during their lives, even in supported and adjusted workplaces (Försäkringskassan, 2020). This scheme was also criticized for not activating and encouraging individuals to return to the labour market (RiR, 2005:14). To overcome this, the ability to work is being continuously evaluated and since 2008, individuals get a right to a benefit that is limited in time and needs to be reassessed continuously. Furthermore, everyone who has a disability benefit (both types of it) can receive it fully or partially. This means, that it is possible to work part-time and get part of the benefit. To encourage the reintegration into the labour market, individuals who have the right to a full or partial sickness compensation can apply for part-time work or increase their working time without losing their right to the benefit. Benefits allocated after July 2008 can be put on hold for up to two years after receiving it for at least one year (Försäkringskassan, 2020).

The implemented reforms had a large effect on disability benefit eligibility. Measuring the immediate effect (2-3 years) of the reforms of the years 1991 and 1997, Karlström et al. (2008) concluded that the number of the disability benefit recipients in the age group of 60-64 has decreased, but it was more due to a spill over to the sickness insurance and the unemployment insurance rather than higher 
participation in the labour market. When considering the effect of the reforms in the early 2000 s for all the age groups, it is interesting to compare the data of the disability benefit take up. The data from 2006, when the take up was extremely high (almost 560000 recipients), and 2019 (ca. 271000 recipients), indicate that the number of recipients decreased substantially (Försäkringskassan, 2020). In the long run, these reforms have mainly affected more privileged people, i.e., the ones with better health, higher education and income, and born in Sweden. Now only the ones with the poorest health get access to disability benefits, whilst others have the option to apply for sickness insurance, unemployment insurance or to take out an early pension, when there are no possibilities to participate in the labour market (SOU, 2020:69). The social insurance pathway to exit labour market is slightly more common among women compared to men, this could be due to poorer self-assessed health or a lacking access to the labour market, which seems to create inequalities between the genders (see Chapter 3). Low-income earners were always overrepresented among disability benefit recipients, which is probably also related to poor health and low education, limiting the labour market participation. Even though the income inequalities among older people have been increasing, this is not related to changes in disability benefits, neither for more privileged groups nor for the ones with the poorest health (SOU, 2020:69).

\subsubsection{Attendance allowance}

Attendance allowance is an allowance which covers the expenses for the personal assistance for a disabled person. Individuals who are covered by the Act regarding Support and Service for People with Certain Functional Impairments (LSS), are insured in Sweden, and need assistance for 20 hours or more per week are eligible to have personal assistants. The 20 hours per week are compensated by municipalities and the remaining time is covered by the Swedish Insurance Agency (Försäkringskassan). Personal assistance was introduced in 1994, regulating that these assistants can be family members or professionals and they can get paid from the attendance allowance (Försäkringskassan, 2020). Individuals with a disability cannot be older than 65 years when applying for this allowance but has a right to keep it after turning 65 (Försäkringskassan, 2020). This is how care work is financed, which is still to a big extent provided by women, as was described in the earlier chapters of this report. As mentioned above, if the support is not provided by family members, one can hire other individuals and pay them for the care work. In this way personal assistance is providing more opportunities for women to stay in the labour market. As it tends to be older workers and especially women who take over caring responsibilities, the option for personal assistance enables the option to either get paid for caring responsibilities or to shift caring responsibilities to a family-external personal assistant. Choosing an external personal assistant frees up time for work and enables more full-time employment. This is especially important 
in the light of increasing longevity, which goes along with an increased demand for care.

\subsection{Labour market inclusion}

\subsubsection{Active labour market policies}

As it was mentioned in Chapter 1, there are no special labour market policy programmes provided by the Swedish Public Employment Service (Arbetsförmedlingen) aimed at labour market integration of older workers as they exist for young people and newly arrived migrants. Hence, the chances of reintegration into the labour market for older people depend on other factors, especially which sector they work in and whether they work as a blue- or whitecollar. This might lead to some inequalities among older workers.

Unemployment benefits are administered by the social partners and paid via special unemployment insurance funds. The monthly contributions are paid by the employees. The benefits can be received up to a month before an unemployed person turns 65. Simultaneously, membership in the employment insurance fund is also terminated. An unemployed person is then directed to take out a pension. This barrier remains for a few decades - when the pension age was changed from 67 to 65 in 1976, the unemployment benefit access upper age limit was adjusted in parallel. Even though the upper pension age in Sweden does not exist anymore (if not to consider 'LAS age', see further), the unemployment insurance retains this limit (SOU, 2020:69).

Complementary to the national labour market policies and unemployment insurance, the services are regulated in the collective agreement called Omställningsavtalen, which can mean 'job security agreements, career transition agreements or redundancy support agreements' (LO, 2021). The agreement is made between trade unions and employers organisations and aims to provide competence development possibilities for individuals who were laid off, so that they can find another employment. It covers almost all the employees in Sweden and is usually funded by setting aside $0.3 \%$ of the salary. The agreements are operated by special foundations. There are few main organisations which cover different sectors in Swedish labour market (LO, 2021).

Blue-collar workers in the private sector are covered by the agreement between The Swedish Trade Union Confederation $(L O)$ and Confederation of Swedish Enterprise (Svenskt Näringsliv), administered by Trygghetsfonden since 2004. It includes only full-time employed until the age of 65 . The foundation's statistics show that the reintegration to the labour market gets more complicated with the age. Within 12 months after the notice, 90\% of 20-39 year olds get re-employed, $85 \%$ in the group of $40-49,83 \%$ in $50-59$ and $60 \%$ among the ones $60+$. Whitecollar workers in the private sector are covered by the agreement between the 
Council of Negotiation and Cooperation (PTK) and the Confederation of Swedish Enterprise (Svenskt Näringsliv), administered by Trygghetsrådet since 1974. Here the same age barrier, 65 years, is in place and according to the statistics, $80 \%$ of those 60+ get employed, start education or start their own company within 12 months after a lay-off. Not only being a blue-collar or white-collar worker, but also the place of birth seems to play an important role for the length of unemployment. For the 55-64 year-olds, 6\% Swedish-born people without high-school degree started working again every month, compared to $4 \%$ foreign-born with a highschool degree (Lindell, 2018). Employees in the municipalities and regions are covered by the agreement between Swedish Association of Local Authorities and Regions (SKR), Municipal Employers' Organisation (Sobona) and trade unions within municipal and regional sector. This collective agreement, called KOM-KL, is administered by Omställningsfonden. The agreement follows the LAS-age (see below) and covers employees who are permanently or temporary employed and employees who were absent due to the sickness or individuals who have accomplished rehabilitation. According to the statistics, older workers were not more disadvantaged in terms of labour market reintegration. On the opposite, the older receivers of the funds have a slightly better chance to be employed. The fund pays a lot of attention to the competence and skills and promotes lifelong learning. It identifies specific needs for the groups of employees in the sector and aims to increase their employability via education and training. In the state sector, the collective agreement is between The Swedish Agency for Government Employers (Arbetsgivarverket) and the trade unions in the sector and is administered by Trygghetsstiftelsen. As most of the above agreements, it covers people up until the age of 65. Statistics show that for people below 55 years, it takes on average 9 months to come back to employment, the period doubles to 18 months for age group 55-59 and further increases to 16 months for those who are 60+ (SOU, 2020:69).

\subsubsection{Employment protection}

Turning to the labour market policies, the key legislation here is the Employment Protection Act, also called 'LAS'. It is constituting a guarantee for the employment protection of all the employees who have a permanent employment contract (that can also mean short-term contracts). The employees are arranged in a certain priority list, based on qualifications needed and duration of employment (where employees working longer have a priority). LAS implies that an employer needs to present a valid reason for a layoff, where age is not one of them. In situations of reorganization or a reduced labour demand, the priority list is invoked and those (higher) on the list have more protected rights to stay employed (Ds, 2018: 28; Lowen, 2016).

As discussed in Chapter 1, the introduction of LAS in the 1980s reduced employment protection for older individuals, facilitated the lay-off of older 
employees and made employees over the age of 67 more vulnerable for job loss. Recently, efforts are made to prolong working life as well as protect older workers and policies are introduced to protect employment for older workers.

An employer can lay off an employee who is older than 68 years (69 years from 2023) without presenting a valid reason. The above-mentioned 'window' is also removed. The period of notice for the employment termination remains to be one month and the above-mentioned employees are removed from the priority list (Riksdag, 2019). The earlier regulation with the 'window' for laying off employees was acting as a certain marker for retirement age. For instance, state, municipal and regional employers automatically terminated employments for those who would reach 'LAS age'. An employee could then be re-employed and as a rule, various temporary contracts would follow. After the above-mentioned reform, this practice was terminated and employees can maintain permanent employments, though losing the place in the priority list (SOU, 2020:69). This might eventually affect the share of temporary employed workers at an older age (see Chapter 3). But this does not mean that all the employees continue working after turning 68. State, municipal and regional employers use the 'LAS age' as an occasion to have a dialogue with the employees about the work and retirement plans (SOU, 2020:69).

\subsubsection{Ageism and age discrimination}

Age discrimination in Sweden is covered under the Discrimination Act (2008: 567) and is implemented under the auspices of the Equality Ombudsman (DO). It is the governmental agency working to promote equal rights and fight discrimination based on gender, transgender identity or expression, ethnicity, disability, sexual orientation, and age. Age discrimination means that a person is disadvantaged based on the 'length of the life reached'. Age as a ground for discrimination was introduced in the legislation only in 2009 (DO, 2020; Discrimination Act, 2008:567). In 2013, the discrimination based on age was expanded from labour market area to also consider health care, social services and goods (SOU, 2020:69). According to statistics ${ }^{6}$, most of the complaints that reach the DO are based on ethnicity and disability - 700-800 per year during 2017-2019. These causes are followed by gender (350-400 cases) and age. There is a slight yearly increase in the complaints based on age discrimination apart from 2016. There is no clear explanation for the latter (see: Table 3; DO, 2020).

${ }^{6}$ Unfortunately, the available statistics is not displayed for various age groups and encompasses both, younger and older people. 
EXCLUSION AND INEQUALITY IN LATE WORKING LIFE

WORKING PAPER 5:

EXCLUSION AND INEQUALITY IN LATE WORKING LIFE: NATIONAL COUNTRY

CONTEXT - SWEDEN

Table 3: The complaints submitted to DO on age discrimination

\begin{tabular}{|l|c|c|c|c|c|c|}
\hline Year & $\mathbf{2 0 1 4}$ & $\mathbf{2 0 1 5}$ & $\mathbf{2 0 1 6}$ & $\mathbf{2 0 1 7}$ & $\mathbf{2 0 1 8}$ & $\mathbf{2 0 1 9}$ \\
\hline $\begin{array}{l}\text { Number of } \\
\text { complaints }\end{array}$ & 269 & 280 & 210 & 274 & 305 & 304 \\
\hline
\end{tabular}

Source: DO 2019, 2016.

Both men and women report discrimination experiences equally often and a higher share of the discrimination complaints relate to only one cause. When it comes to intersections, for instance, in 2019, 59 cases were based on age and ethnicity, 57 on age and gender and 48 on age and disability. It should be taken into consideration that the share of unreported cases is high, which makes it difficult to account for the real extent of discrimination (DO, 2020).

The Discrimination Act concerns all areas of life and encompasses discrimination in the labour market as well as in society (Discrimination Act, 2008:567). Based on the number of complaints submitted to the DO, the most common area of discrimination in 2017 to 2019 was working life and institutions as well as organisations related to it. Around 1200-1500 complaints reached DO yearly under 2017 to 2019. The vast majority experience discrimination in their working life. This was also the most common area for complaints based on the grounds of age (149 in 2019) (DO, 2020).

An experimental study exploring age discrimination in the recruitment process conducted in 2015 to 2016 concludes that older individuals are more disadvantaged. Researchers sent 6 ooo fictional job applications with random qualifications and various ages (35-70) to recruiters. It revealed that the likelihood to be contacted decreases dramatically after 40 years of age and starting from the normative pension age of 65 , the chances to be contacted were only around $2-3 \%$. The trend of being contacted less with increasing age was more pronounced among women. A possible explanation for this trend is that people over the age of 40 are not considered young anymore. Not being perceived as young relates to stereotypes about having difficulties to learn new things as well as lacking flexibility and initiative (SOU, 2020:69).

In employment situations, discrimination can take place in all aspects and phases of the working life. Therefore, since 2017, the Discrimination Act obliges employers to actively promote equal rights and opportunities in the workplace (Discrimination Act, 2008:567). Based on this, there are four of these active measures. First, five areas need to be continuously investigated, analysed, measures need to be taken, and monitoring/evaluation carried out. These areas are: '(1) working conditions; (2) provisions and practices regarding pay and other terms of employment; (3) recruitment and promotion; (4) education and training and other skills development; (5) possibilities to reconcile gainful employment and 
parenthood'. It is important to not only take tangible barriers for equal rights and opportunities, but also 'attitudes, norms and structures' into consideration. Second, gender balance in various occupations should be promoted. Third, guidelines and routines preventing harassment, sexual harassment and reprisals need to be in place, followed up and evaluated. Fourth, employers must carry out annual pay surveys (DO, 2020).

The questionnaire distributed in 2017 showed that a share of the employers was not aware of the amendments in the Discrimination Act that altered their obligations for the active promotion of the equal rights and opportunities. DO provided information campaigns as well as toolkits to implement these active measures (DO, 2020), but their effect is not yet clear.

To date, there is still not much research available on age-based discrimination in the working life and many discrimination cases are deemed unreported (Abramsson et al., 2017; DO, 2020). Age discrimination in the labour market is difficult to prove, if the cases reach the court. Employers might for example not directly and openly discriminate in the recruitment process, but instead set certain requirements, which disadvantage older individuals. There is a general lack of measures to sanction the discrimination in the labour market and discriminatory practices among employers go unpunished (SOU, 2020:69). Therefore, it is hard to know what the overall effects of the Discrimination Act are for various groups of society, including older individuals.

\subsubsection{Lifelong learning}

As it was mentioned in Chapter 1, education and lifelong learning is currently lying in the domain of the state and the individual. The employer has the responsibility to educate staff to be able to carry out their working tasks but has no official commitment beyond that. The main obligation for the education provision lies in state-funded institutions, which also encompass free of charge vocational and higher education. To support individuals choosing further education, the state provides student loans. They are administrated by The Swedish Board of student Finance (CSN).

In 2015, the Swedish Government instigated a commission 'Mission: Future' (Uppdrag: Framtid) to develop policies, which would meet the challenges of the future. One of the three working groups formed was called 'Work in the future' (Arbetet i framtiden) and operated for about a year during 2015 to 2016 (Regeringen, 2016). The group produced multiple reports and three of them were emphasising the importance of lifelong learning. The results highlighted the importance of education equipping individuals with the skills and knowledge needed, preparing them for labour market participation, continuously developing their skills and training new employees. In fact, most changes in the Swedish labour market are related to individuals changing jobs compared to people coming in and 
out of the labour market - accordingly around 10\% to 4-5\% yearly change7 (Nordström et al., 2016). Thus, the reform of lifelong learning possibilities for the individuals already in employment is deemed to be 'the most important future reform to ensure a high employment rate, low unemployment, and a reduction in gaps' among individuals (Nordström et al., 2016: 3).

The Government made an assessment 'Higher education over twenty years' (Högre utbildning under tjugo år) on the higher education provision in 2015 and found that many universities are providing so called 'commissioned training' (uppdragsutbildning) that is purchased by the employers and then adjusted to the needs for the particular competences and skills. A supply of this type of education was suggested to be the main way of lifelong learning education for organisations. More women than men are taking part in commissioned training (Herjevik et al., 2016). The most represented group in commissioned training are women over the age of 35 , while men at that age as well as both genders in younger age groups, are taking part in commissioned training to a much smaller extent (Herjevik et al., 2016). Another type of education is single-subject courses that can be taken outside of the program, are also considered an important part of lifelong learning and usually attract older students. Single-subject courses are more popular among women compared to men (SOU, 2015:70). The supply of these courses has been declining during the latest years and further decrease of this type of education is not recommended. The same applies to the summer courses that can be seen as a way to shorten education (SOU, 2015:70).

The above-mentioned working group proposed a reform based on two pillars. Firstly, measures that need to be taken to widen the current system and enhance a compatibility between the supply and demand for the existing education and skills development activities. Secondly, measures to broaden the system of lifelong learning (Nordström et al., 2016).

To begin with the first pillar, the possibilities for the professionals to further educate themselves depend on (1) the available supply of education, (2) the match of this supply to current needs of the labour market and (3) the accessibility of education (Landell, 2016). All of these areas need to be improved, so that education matches the needs of the individuals in terms of its focus and form. The professionals should get real access to the education provided (Nordström et al., 2016).

The second pillar proposes to build a new system focused on lifelong learning. Its central aims are threefold: 
- The information about support in recurring skills development should be a natural part of the working life;

- Individual counselling for the 30+ year olds active in the labour market in order to support them in recognising their competences and possible ways to develop their skills;

- 'Skills insurance' (kompetensförsäkring) providing individuals with the economic possibilities to participate in skills development activities in the middle of the working life.

The reform proposes to establish a new structure for lifelong learning, where roles and responsibilities among the social partners - state, trade unions and employers' organisations - and public actors should be defined. Further, there is a need for an organization responsible for safeguarding that all aspects of lifelong learning would be implemented in the whole labour market. This organization would follow the demand of skills among the employed and in collaboration with other actors ensure that the supply of the available education matches this need for lifelong learning.

Finally, the proposal suggests that the government should initiate an enquiry into how such a new system could be formed and would discuss the roles and financing with the trade unions and employers' organisations. There is also a need for discussion if and in what situations individuals should be required to participate in the activities of skills development (Nordström et al., 2016). The newly presented report by another group, the 'Delegation for older labour' (Delegationen för senior arbetskraft), also emphasises the importance of the lifelong learning for the extended working life. The commission agrees that all labour market actors should take responsibility in contributing to lifelong learning (SOU, 2020:69).

Lastly, it is important to discuss new solutions for parts of the employment protection in the above-mentioned Labour Protection Act (LAS). The working group emphasised that the security of the employed lies to a higher degree in their skills and to a lower degree in the total employment time (Nordström et al., 2016). Keeping in mind that the so called 'rank' of most and least protected employees for lay off is also based on the length of employment, the group is basically proposing to put more focus on the skills. It is not clear how that would affect the older employees, but it would definitely look away from the merits based on the length of employment history in a particular organization allowing more flexible circulation of the labour force as opposed to the traditional long(er) careers at the same workplace. Even though the working group does emphasize that this reform is meant for adjusting the current regulations to a new lifelong learning system and is not intended to 'worsen the protection of the employed nor to change the power relations' among the social partners (Nordström et al., 2016). As it is seen from the account on LAS presented earlier in the text, the 'rank' system was not changed and the balance between the length of employment at the workplace and the skills needed has not changed. 
There were few instigated changes in line with the working group's and Government evaluation's conclusions. The accessibility to higher education was expanded by raising the number of permanent education places in vocational education and higher education in the whole country, so that education would be available in all the regions. The latest increase in higher education places is also related to the measures in face of the Covid-19 pandemic (Regeringen, 2015; Regeringen, 2020a). The proposed changes in the Higher Education Act imply more freedom for the institutions and the clarified role of these institutions in lifelong learning in forming their education supply in relation to students' demand and the labour market needs (Regeringen, 2020b). Lastly and most directly related to late working life, a proposal has been issued to amend the rules for the CSN support by raising the maximum age limit from 56 to 60 years and including it in the budget as of January 1, 2021 (Regeringen, 2019). Currently an access to study loans is reduced stepwise already from the age of 47 with the ceiling of 56 years. A certain centralised state support - studies start support (studiestartsstöd) - is available for municipalities to' include people into the education system, so that their employability is improved. It is currently also available until one turns 56 years old (SOU, 2020:69).

\subsection{5 'Silver work'}

In order to prolong the working lives of individuals, the Swedish state is using tax relief incentives for the employers to hire older people. Since the $1^{\text {st }}$ of July 2019, employing people who have turned 65 years became 'cheaper'8. The well-known high Swedish employer income tax contribution (arbetsgivaravgiften) rates are lowered by $6.15 \%$, from $16.36 \%$ to $10.21 \%$ (Carlgren, 2019; Regeringen, 2019). This was not the first time the government introduced it. In 2007, the employer income tax contribution rate was lowered from $26.37 \%$ to $10.21 \%$ when employing 65 yearolds and older (Carlgren, 2019). These measures do not affect the net income, but another incentive does. The employment tax deductions (jobbskatteavdraget) are directly targeting the lower income earners (lower income earners are often characterised by weak position on the labour market, low education, poor health condition, etc.) by reducing their income tax and in that way raising their net income. These deductions are more generous for older workers. Since 2009, people who are 65 and older and still in the labour market have an automatically higher limit from which the employment tax should be paid (förhöjt grundavdrag). In 2020, no income lower than 52600 Swedish crowns is taxed (SOU, 2020:69).

8 These measures apply also for self-employed. 
These incentives are meant to encourage employers to hire older people and for employees to stay in the labour market for longer. The common understanding that it is more expensive to hire older employees is challenged by reducing the employer's income benefit as well as keeping in mind that many costs for insurance benefits regulated in the collective agreements are also taken away after the employee turns 65 (e.g., occupational pension contributions are not paid anymore) (SOU, 2020:69). These measures potentially can have positive effects on the increase of labour market participation and the actual prolongation of the working life (Carlgren, 2019; Laun \& Palme, 2017). On the other hand, they are still not widely known and stereotypes about expensive older workers pertain (SOU, 2020:69).

\subsubsection{HR strategies and age-sensitive leadership}

HR strategies and leadership have an important role in retaining older workers in the labour market. The workplace policies go beyond a mere age discrimination as described above (section 4.3.2.). These policies are often age-neutral and are in that way understood as just and non-discriminatory, but they are not norms-neutral and do not always contribute to the prolonged working life. Three key HR routines recruitment, development, and salary dialogues - are discussed in a report by the delegation for older labour. The norms and understandings about who is an older worker, what the common pension age is or that an employee should be primarily adjusting to the working tasks, affect these routines. The societal and organisational norms that are institutionalised over time, also affect the managers' view of the older workers and standardised processes do not always consider individual needs. That is why, it is important to talk about age-sensitive leadership instead of an ageneutral one. There is a need for a strategic and coherent planning to maintain the older workers' competence. This should be done before the pension decisions need to be taken. For instance, planning and including employees in the education and training as well as showing appreciation for employees' work should be taken into consideration. Not many organisations have a well-developed and functioning agerelated policy. Here both, the managers' and HR staff roles are important (SOU, 2020: 69).

It is important to underline that the attitudes and norms, both positive and negative, affect the decision whether to stay in the labour market or not. Stereotypes, like e.g., that older people are less capable of learning new things, affect the actual motivation to learn. These attitudes and norms affect the working environment and can act as a 'nudge' towards deciding to retire in a structural way (SOU, 2020:69). Studies show that there are various understandings on what is the age defining an 'older' person. Looking at the employers' attitudes towards jobseekers in recruitment processes, Carlsson and Eriksson (2019) found that an older worker was on average thought as someone above 54 years old. Nilsson's (2019) study shows that in the municipality sector, the managers thought that both 
their male and female employees are older when they are on average 59 years old. Thus, the norms and attitudes are also related to the specific sectors, branches and workplaces. Employers at workplaces with older employees have more positive attitudes (SOU, 2020:69) and managers in the municipal sector who would like to work beyond 65 years, find it important to keep employees longer. Managers in municipal sectors also see a need to retain older workers with the right skills, because of the labour force shortages. Older employees' competence and acquired knowledge can be transferred to younger workers and used in mentoring. Older employees are also seen as more loyal and meticulous in their work. Most of the managers in the municipal sector stated that older workers have difficulties to accept changes, are not as flexible, innovative, have lower education and a more negative view towards new technology compared to younger workers. Around half thought that older workers are slower and less productive (Nilsson, 2019). There is a general tendency among employers to underestimate the productivity and overestimate the labour costs for older workers, but it varies by sector and branch. In the municipal sector employers see this relation as more positive among older than younger workers. The same holds in construction and educational sectors. The opposite situation is more common in state and private sectors as well as such branches as trade, communication, transport, finance and care sectors. Here the productivity-labour costs balance is thought to be better among younger employees. There were no differences depending on the size of the company or if the sector was male or female dominated, but female employers were more positive towards older employees. Due to reduced employer income tax contribution and terminated payments for the occupational pension, it is often cheaper to employ individuals older than 65 years (SOU, 2020:69).

To conclude, there is a clear trend in recent policies to prolong working life and protect the rights of older workers. Older workers are now better protected against losing their jobs and anti-discrimination legislation now includes ageism. The Swedish health insurance system was modified to incentivize people to start working again and to not leave the workforce completely. Even though there are still stereotypes against older workers, especially in certain branches, different policies made employing older workers cheaper and more gainful for employers.

\section{$5 \quad$ Concluding points}

Two issues appear to be specific for the Swedish case. Firstly, the demographic situation, where the share of an older population is increasing, but without a fertility crisis. However, the improving longevity/health is not mirrored in the labour market participation. The latter sharply drops after the age of $65-$ a trend that is related to the regulations and norms regarding retirement transition. In 
comparison to the other EU countries, Swedish retirement age is relatively high, but it is being postponed and working life is extended. Secondly, the particular social model that designates the field of industrial relations for the social partners - TUs and employers - and leaves the state with the responsibility for the macroeconomic stability, generous redistributive welfare as well as assurance of full-employment and the education system. Nevertheless, the social model is changing and is faced with challenges.

The austerity and dismantling as well as privatisation of the welfare (e.g. in health care, elderly care and education) brings up debates on the neoliberal turn. When looking at the latest changes in the migration policy, right wing nationalistic and populistic trends are also visible in the Swedish public discourse. Both trends are somewhat contradicting the prevailing image of Sweden as an ideal solidaristic welfare state and some authors point out the end of the 'Swedish exceptionalism' (Schierup \& Ålund, 2011).

The Swedish model, (especially the good labour conditions and high wages, but also the TUs' power) has also been challenged by the EU's common market for decades. The most recent debates are related to mobility of services and workers as well as plans for the minimum wage regulations. In these debates it is important to consider gendered labour market inequalities and older workers' circumstances. As labour market inequalities are often manifested in involuntary temporary or parttime employments, these employments should be included in employment protection.

Inside policy debates indicate issues of gendered labour market inequalities, poverty among pensioners and problems to financially sustain the pension system. Issues such as labour force shortages as well as lack of demanded skills impede economic growth and international competitiveness and are highly visible in the discourses of all partners. The main difference between the TUs and employers' organisation is the suggested strategies to counteract these problems. While the TUs emphasise life-long learning as a solution to labour force shortages, the employers' organisations favour facilitated conditions to replace employees who do not have the required skills. The latest policy debates in relation to Employment Protection Act (LAS) indicate the differences among the social partners' positions based on where on the security vs. flexibility continuum they stand. There are still stereotypes prevailing against older workers. While in some contexts, older workers with special skills are highly valued, many employers still see older employees in a negative light due to stereotypes. To counteract stereotypes and discrimination, the Discrimination Act includes a passage on age discrimination since 2009. Also, employers are incentivised to employ people above the age of 65 through financial benefits. Regarding the above-mentioned security vs. flexibility continuum, policies are increasingly striving towards security by protecting employment of older workers and thereby contributing towards prolonging working lives. 
Although extending working lives has become an increasingly important point on the political agenda, the labour market is still coined by inequalities, especially among older workers and for women in particular. There are still older workers in involuntary part-time or temporary employments and factors such as socioeconomic status as well as gender unequally impact late working lives. It remains to be seen how the COVID-19 pandemic affects labour market inequalities and working conditions for older workers. The pandemic not only changes working lives, but also affects workers' health and ability to work. On top of that, the COVID19 pandemic might increase stereotypes against older people, which could in turn affect the employability of older workers. As prolonging working lives is viewed as a promising solution to securing welfare financing, the trend towards improving working conditions and employability of older workers should be continued and inequalities should be reduced throughout the lifecourse. 


\section{$6 \quad$ References}

Abramsson, M., Hydén, L. C., \& Motel-Klingebiel, A. (2017). Vem är den äldre? Äldrebilder $i$ ett åldrande Sverige. Stockholm, Sweden: Regeringskansliet Kommitteservice.

Ahmed, A.M., Andersson, L., \& Hammarstedt, M. (2012). Does age matter for employability? A field experiment on ageism in the Swedish labour market. Applied Economics Letters, 19, 403406.

Andersson, K., \& Kvist, E. (2015). The neoliberal turn and the marketization of care: The transformation of eldercare in Sweden. European Journal of Women's Studies, 22 (3), 274287.

Arbetsförmedlingen (2021). Om oss. Retrieved from https://arbetsformedlingen.se/om-oss

Arbetsmiljöverket (2018). Arbetsmiljön 2017. Arbetsmiljöstatistik Rapport 2018 (2).

Arnek, M. (2012). Skäl till att gå i pension eller inte. Pensionsmyndigheten analyserar 2012 (1). Stockholm: The Swedish Pensions Agency.

Bengtsson, T., \& Scott, K. (2011). Population ageing and the future of the Swedish welfare state. Population and Development Review, supplement, 37, 158170.

Bergold, J., Vedin, U., \& Lorentzi, U. (2020). Sveriges jämställdhetsbarometer 202O. Tid, makt och pengar - jämställda och jämlika möjligheter att försörja sig livet ut. Stockholm, Sweden: Landsorganisationen i Sverige.

Blomqvist, P., \& Palme, J. (2020). Universalism in Welfare Policy: The Swedish Case beyond 1990. Social Inclusion, 8 (1),114123.

Carlgren, F. (2019). Billigare att anställa äldre igen. Retrieved from https://www.ekonomifakta.se/Artiklar/2019/juli/billigare-att-anstalla-aldre-igen/

Carlsson, M., \& Eriksson, S. (2018). Bortvald på grund av ålder ålderdiskriminering vid rekryteringar. Rapport 11, Delegationen för senior arbetskraft, $S 2018$ (10).

Dagens Industri (2018). LAS-åldern ska höjas. Retrieved from https://www.di.se/nyheter/regeringen-vill-hoja-las-aldern/

Dagens Nyheter (2019). DN Debatt. Regeringen måste stoppa EU-förslaget om minimilön. Retrieved from https://www.dn.se/debatt/regeringen-maste-stoppa-euforslaget-om-minimilon/ 
Dagens Nyheter (2020). DN Debatt. En europeisk minimilön drabbar löntagarna i Norden. Retrieved from https://www.dn.se/ledare/replik-en-europeisk-minimilondrabbar-lontagarna-i-norden/

Dahlqvist, H. (2020). A critique of the grand narrative of the Swedish model. Labor History, 61, 247266.

Dahlstedt, M., \& Neergaard, A. (2019). Crisis of Solidarity?: Changing Welfare and Migration Regimes in Sweden. Critical Sociology 45 (1), 121135.

Discrimination Act (2008:567). Stockholm: Regeringskansliet.

DO (2020). Ålder som diskrimineringsgrund. Retrieved from www.do.se

Ds (2018: 28) .Förlängt anställningsskydd till 69 år. Stockholm, Sweden:

Regeringskansliet, Arbetsmarknadsdepartamentet.

Ebbinghaus, B. (2019). Pension reforms and old age inequalities in Europe: From old to new social risks? Paper presented at the European Sociological Association Conference, Manchester, UK.

Engström, L.-G., Heikkinen, S., \& Krekula, C. (2020). Sweden. In Á. N. Léime, J. Ogg, M. Rašticová, D. Street, C. Krekula, M. Bédiová, \& I. Madero-Cabib (Eds.), Extended Working Life Policies. International Gender and Health Perspectives. Springer Open.

Esping-Andersen, G. (1990). The Three Worlds of Welfare Capitalism. Cambridge, UK: Polity Press.

ETUI (2020). National Industrial Relations. Sweden. Retrieved from https://www.worker-participation.eu/National-IndustrialRelations/Countries/Sweden/Health-and-Safety

Försäkringskassan (2020). Sjuk minst 1 år. Retrieved from https://www.forsakringskassan.se/privatpers/sjuk/sjuk minst 1 ar

Fransson A., \& Söderberg M. (2019). Hur mycket arbetar seniorer? Rapport 7, Delegationen för senior arbetskraft. Stockholm, Sweden: Regeringskansliet Kommitteservice.

FTF (2018). Det prestationslösa pensionssystemet - en rapport om pensionsgapet mellan inrikes- och utrikesfödda. Retrieved from https://www.forena.se/contentassets/6faoc3f5470946cbaf3124638cc159e7/utrikes sfodda-2018_final2.pdf

Focacci, C. N., \& Lam, P. H. (2020). Why do unemployed people avoid participation in training? An experiment for policy making. Social Policy \& Administration, 54(7), 12311245. 
Galte Schermer, I. (2020). Förtidspensionerade. Retrieved from https://www.ekonomifakta.se/Fakta/Arbetsmarknad/Fortidspensionerade-ochsjukskrivna/Fortidspensionerade/

Guilherme Fernandes, A. (2013). Ethnification of New Social Risks: Programmes for Preparing Newly Arrived Immigrants for (Working) Life in Sweden, Denmark and Norway. In I. Harsløf, \& R. Ulmestig (Eds.) Changing Social Risks and Social Policy Responses in the Nordic Welfare States. London, UK: Palgrave Macmillan.

Hagen, J. (2017). Pension principles in the Swedish pension system. Scandinavian Economic History Review, 65(1), 2851.

Hamskär, I. (2020). Höj den allmänna pensionen 2021. Retrieved from https://blogg.pro.se/2020/03/16/hoj-den-allmanna-pensionen-2021/

Hansen, P. (2018). Asylum or austerity? The 'refugee crisis' and the Keynesian interlude. European Political Science, 17, 128139.

Herjevik, M., Sadurskis, A., \& Eriksson, G. (2016). Uppdragsutbildning vid universitet och högskolor. Redovisning av ett regeringsuppdrag. Stockholm, Sweden: Universitetskanslersämbetet.

Jensen, P.H. (2020). On How Different Combinations of Conditions Produce Different Early Exit/Retirement Outcomes: a Qualitative (Case-Oriented) Comparison of Denmark and Sweden. Ageing and Society, 202O, 1-21.

Karlström, A., Palme, M., \& Svensson, I. (2008). The employment effect of stricter rules for eligibility for DI: Evidence from a natural experiment in Sweden. Journal of Public Economics, 92, 20712082.

Krekula, C., \& Vickerstaff, S. (2020). The 'Older Worker' and the 'Ideal Worker': A Critical Examination of Concepts and Categorisations in the Rhetoric of Extending Working Lives. In Á. N. Léime, J. Ogg, M. Rašticová, D. Street, C. Krekula, M. Bédiová, \& I. Madero-Cabib (Eds.) Extended Working Life Policies. International Gender and Health Perspectives. Springer Open.

Laun, L., \& Palme, M. (2018). Kan seniorer arbeta längre?. Rapport 1, S 2018:1O. Stockholm, Sweden: Delegationen för senior arbetskraft.

Laun L., \& Palme M. (2020). Pensionssystemens drivkrafter för ett längre arbetsliv. Rapport 23, $S$ 2018:10. Stockholm, Sweden: Delegationen för senior arbetskraft.

Landell, E. (2016). Utbildningsutbud för livslång lärande $i$ arbetslivet. Underlagsrapport till analysgruppen Arbetet i framtiden. Uppdrag: Framtid.

Lindell, H. (2018). Äldres arbetsmarknadssituation. Stockholm, Sweden: Arbetsförmedlingen.

LO (2020). LO kräver att den S-ledda regeringen sätter jämlikheten främst.

Retrieved from 
EXCLUSION AND INEQUALITY IN LATE WORKING LIFE

WORKING PAPER 5:

EXCLUSION AND INEQUALITY IN LATE WORKING LIFE: NATIONAL COUNTRY

CONTEXT - SWEDEN

https://www.lo.se/start/nyheter/lo kraver att den_s ledda regeringen satter $j$ amlikheten framst

LO (2021). Insured life events. Retrieved from

https://www.lo.se/english/social security/insured life events

Lowen, T. (2016). Lagen om anställningsskydd (LAS) - rätten att säga upp den anställde vid 67 års ålder. Pensionsmyndigheten Report, 1 (15). Stockholm, Sweden: The Swedish Pensions Agency.

Lundberg, K. (2020). Demografi, hälsa och sysselsättning - en internationell utblick. Rapport 16, S 2018:10. Stockholm, Sweden: Delegationen för senior arbetskraft,.

Magnusson, L. (2007). The Swedish Labour Market Model in a Globalized World. Retrieved from http://library.fes.de/pdf-files/bueros/stockholm/05005.pdf

Malmberg, B., \& Clark, W. (2020). Migration and neighbourhood change in Sweden: the interaction of ethnic choice and income constraints. Geographical Analysis 53(2), 124.

Ministry of Health and Social Affairs (2016). The Swedish old-age pension system. How the income pension, premium pension and guarantee pension work. Stockholm, Sweden: Government Offices of Sweden.

Nielsen, K. J. (2017). A comparison of inspection practices within the construction industry between the Danish and Swedish Work Environment Authorities.

Construction Management and Economics, 35(3), 154169.

Nilsson K. (2019). Chefers attityder till sina äldre anställda. Rapport 15, S 2018:10. Stockholm, Sweden: Delegationen för senior arbetskraft.

Pensionsmyndigheten (2020a). Korta pensionsfakta. Retrieved from

https://www.pensionsmyndigheten.se/nyheter-ochpress/pressrum/kortapensionsfakta

Pensionsmyndigheten (2020b). Höjd pensionsålder och höjd garantipension från 2020. Retrieved from https://www.pensionsmyndigheten.se/forsta-dinpension/om-pensionssystemet/hojd-pensionsalder-2020

Perez, C. (2003). Technological revolutions and financial capital. Cheltenham, UK: Edward Elgar Publishing.

PRO (2014). Fattigdomsfällan - så drabbar pensionssystemet många kvinnor. Stockholm, Sweden: PRO.

PRO (2015). Ålderdom utan fattigdom. Om äldrefattigdom och kvinnors låga pensioner. Retrieved from https://pro.se/download/18.a5f223f171ac2fcd6d79a2/1588846100308/Rapport_A ldrefattigdom_40_sid.pdf 
EXCLUSION AND INEQUALITY IN LATE WORKING LIFE

WORKING PAPER 5:

EXCLUSION AND INEQUALITY IN LATE WORKING LIFE: NATIONAL COUNTRY

CONTEXT - SWEDEN

Regeringen (2015). Fler permanenta utbildningsplatser i yrkeshögskolan.

Retrieved from

https://www.regeringen.se/pressmeddelanden/2015/08/fler-permanentautbildningsplatser-i-yrkeshogskolan/

Regeringen (2016). Uppdrag: Framtid. Retrieved from

https://www.regeringen.se/sveriges-regering/statsradsberedningen/uppdragframtid/

Regeringen (2019a). Bättre studiestöd till äldre. Promemoria U2019/o4318/UH. Stockholm, Sweden: Regeringskansliet Utbildningsdepartamentet. Retrieved from https://www.regeringen.se/rattsliga-dokument/departementsserien-ochpromemorior/2019/12/battre-studiestod-till-aldre/

Regeringen (2019b). Viktigare lagar och förordningar inför halvårsskiftet 2019. Retrieved from:

https://www.regeringen.se/4a47e4/contentassets/ofc7401cd1e54275983b331a89f2 384c/viktigare-lagar-och-forordningar-infor-halvarsskiftet-2019.pdf

Regeringen (2020a). Storsatsning på universitet och högskola - så här fördelas platserna. Retrieved from

https://www.regeringen.se/pressmeddelanden/2020/05/storsatsning-pa-hogreutbildning--sa-har-fordelas-platserna/

Regeringen (2020b). Ändringar i högskolelagen för att främja den akademiska friheten och tydliggöra lärosätenas roll för det livslånga lärandet. Promemoria U202O/O3O53/UH. Retrieved from https://www.regeringen.se/rattsligadokument/departementsserien-och-promemorior/2020/05/andringar-ihogskolelagen-for-att-framja-den-akademiska-friheten-och-tydliggora-larosatenasroll-for-det-livslanga-larandet/

Riksdag (2019). Anställningsskyddet förlängs tills arbetstagaren fyllt 69 år . Retrieved from https://www.riksdagen.se/sv/dokumentlagar/arende/betankande/anstallningsskyddet-forlangs-tillsarbetstagaren H601AU12

Riksdag (2020). Kommissionens arbetsprogram 2020. Fakta-PM om EU-förslag 2019/20: FPM19 COM (2020) 37. Retrieved from https://www.riksdagen.se/sv/dokument-lagar/dokument/fakta-pm-om-euforslag/kommissionens-arbetsprogram-2020_H706FPM19

RiR (2005). Förtidspension utan återvändo. Retrieved from

https://www.riksrevisionen.se/download/18.78ae827d1605526e94b2dca8/1518435 508784/RiR_2005_14.pdf

Scarpa S. (2013). New Geographically Differentiated Configurations of Social Risks: Labour Market Policy Developments in Sweden and Finland. In I. Harsløf, R. 
EXCLUSION AND INEQUALITY IN LATE WORKING LIFE

WORKING PAPER 5:

EXCLUSION AND INEQUALITY IN LATE WORKING LIFE: NATIONAL COUNTRY

CONTEXT - SWEDEN

Ulmestig (Eds.) Changing Social Risks and Social Policy Responses in the Nordic Welfare States. London, UK: Palgrave Macmillan.

SCB (2018). Women and men in Sweden 2018 - Facts and Figures. Retrieved from https://www.scb.se/contentassets/4550eaae793b46309da2aad796972cca/leo201_ 2017b18_br_x1obr1801eng.pdf

SCB (2018a). Sveriges framtida befolkning 2018-2070. Demografiska rapporter 2018:1. Stockholm, Sweden: SCB.

SCB (2018b). Vuxnas deltagande i utbildning - personalutbildning och andra former av utbildning. Temarapport 2018:1. Stockholm, Sweden: SCB.

SCB (2020). Utvecklingen till tidsbegränsat anställda 2005-2019. Sveriges officiella statistik, statistiska meddelanden. AM 110 SM 2001. Stockholm, Sweden: SCB.

SCB (2021). Summary of Population Statistics 1960-2020. Retrieved from https://www.scb.se/en/finding-statistics/statistics-by-subjectarea/population/population-composition/population-statistics/pong/tables-andgraphs/yearly-statistics--the-whole-country/summary-of-population-statistics/

Schierup, C., Hansen, P., \& Castles, S. (2006). Migration, Citizenship and the European Welfare State. Oxford, UK: Oxford University Press.

Schierup, C.-U., \& Ålund, A. (2011). The end of Swedish exceptionalism?. Race \& Class 53(1): 45-64.

SOU (2015:70). Högre utbildning under tjugo år. Betänkande av Utredningen om högskolans utbildningsutbud. Stockholm, Sweden: Statens Offentliga Utredningar.

SOU (2020:69). Äldre har aldrig varit yngre - allt fler kan och vill arbeta längre. Betänkande av Delegationen för seniorarbetskraft. Stockholm, Sweden: Statens Offentliga Utredningar.

SPF (2017). Program för seniorrespekt. Stockholm, Sweden: SPF Seniorerna.

SPF (2020). Så tycker vi. Retrieved from https://www.spfseniorerna.se/sa-tyckervi/

Szebehely, M. (2014). Anhörigomsorg, förvärvsarbete och försörjning. In Swedish Delegation for Equality in Working Life (Eds.) Lönsamtarbete -familjeansvarets fördelning och konsekvenser. Stockholm, Sweden: Fritzes.

Svanström (2020). Hur ökar vi den ekonomiska jämställdheten? Retrieved from https://www.tco.se/tco-bloggar/therese-svantrom/hur-okar-vi-den-ekonomiskajamstalldheten/

Svenskt Näringsliv (2020). Frågor vi arbetar med. Retrieved from https://www.svensktnaringsliv.se/ 
SVT (2019). Partier kritiska till europeisk minimilön. Retrieved from https://www.svt.se/nyheter/inrikes/partiledarna-debatterar-om-eu-i-riksdagen

Tallberg, C., Andersson, J., \& Hamskär, I. (2019). Även vi äldre måste få vara trygga på jobbet. Retrieved from

https://www.aftonbladet.se/debatt/a/1no2dK/aven-vi-aldre-maste-fa-vara-tryggapa-jobbet

TCO (2018). TCO-väljarna: Vi behöver inte förändra LAS. Retrieved from https://www.tco.se/Aktuellt/Debatt/2018/tco-valjarna-vi-behover-inte-forandralas/

TCO (2020a). The Swedish Model. Retrieved from https://www.tco.se/globalassets/the-swedish-model.pdf

TCO (2020b). TCO tycker: Arbetsmarknad, Jamställdhet och mångfald, Omställning och utbildning, Partsmodellen. Retrieved from https://www.tco.se/var-politik/

Thörn, C., \& Thörn, H. (2017). Swedish cities now belong to the most segregated in Europe. Sociologisk Forskning, 54(4), 293-296.

Wall, A. (2014). Halva arbetstiden, hela ansvaret: En rapport om kvinnors deltidsarbete. Stockholm, Sweden: The Swedish Municipal Workers' Union.

Wikström, E., \& Ahnlund, P. (2018) Making Refugees Work? Individualized Work Strategies in the Swedish Refugee Settlement Program. Nordic Journal of Working Life Studies, 8(S4), 47-65.

Woolfson, C., Thörnqvist, C., \& Sommers, J. (2010). The Swedish model and the future of labour standards after Laval. Industrial Relations Journal 41(4), 333-350. 
EXCLUSION AND INEQUALITY IN LATE WORKING LIFE: NATIONAL COUNTRY CONTEXT - SWEDEN

\section{$7 \quad$ Appendix}

Figure 23: Average working time a week (measured in hours per week; only paid work is counted in; 2005 marks a change in the age groups definition, thus results are more difficult to compare), 1976-2016

Hours/week

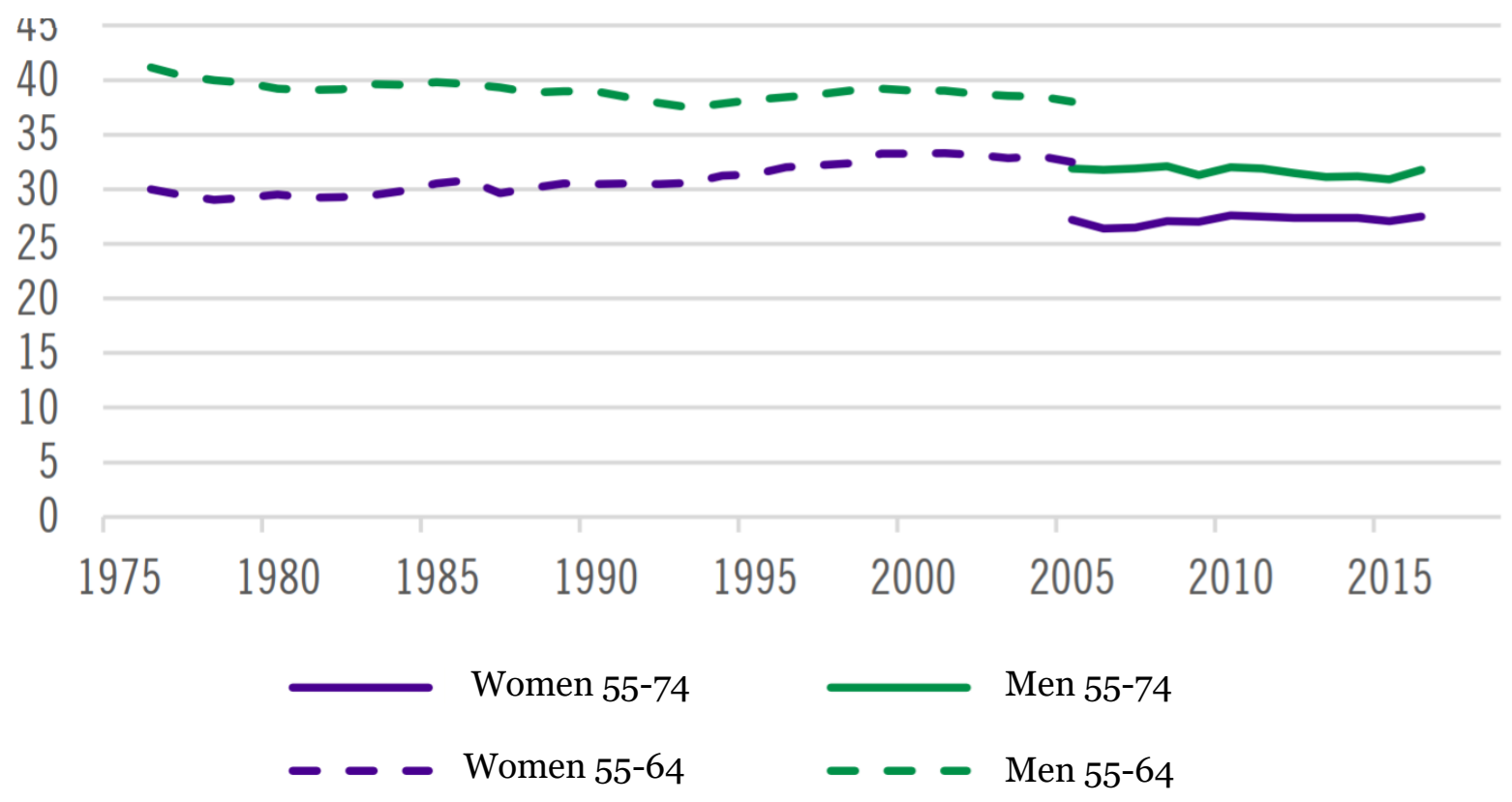

Source: AKU; Laun \& Palme, 2018, p.13. 
EXCLUSION AND INEQUALITY IN LATE WORKING LIFE

WORKING PAPER 5:

EXCLUSION AND INEQUALITY IN LATE WORKING LIFE: NATIONAL COUNTRY

CONTEXT - SWEDEN

Figure 24: Share of the population that is participating in the labour market (by birth cohorts and age; available data is from 2001-2015)
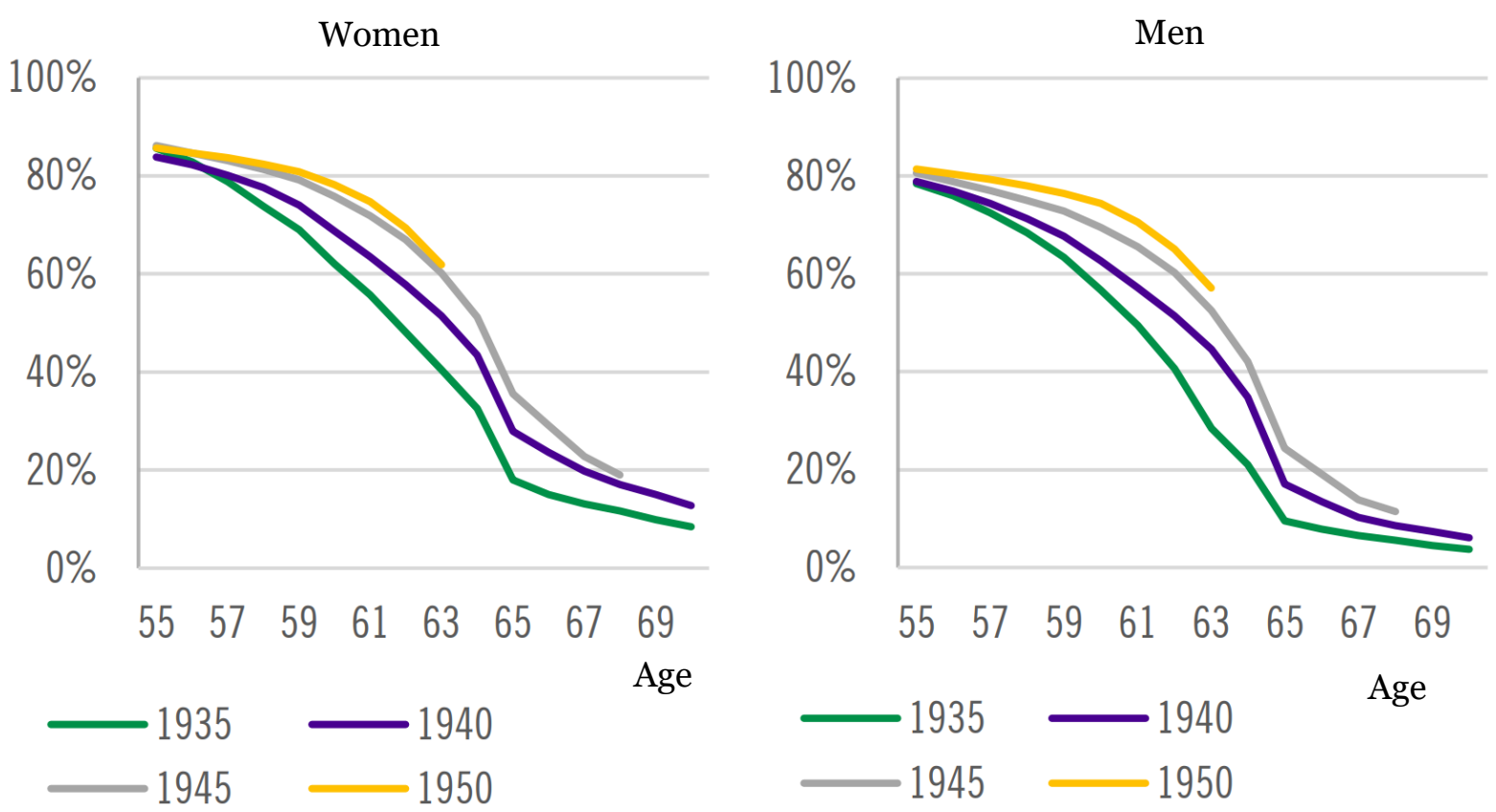

Source: LOUISE-database; Laun \& Palme, 2018, p.14. 
EXCLUSION AND INEQUALITY IN LATE WORKING LIFE

WORKING PAPER 5:

EXCLUSION AND INEQUALITY IN LATE WORKING LIFE: NATIONAL COUNTRY

CONTEXT - SWEDEN

Figure 25: Female (15-74) labour market participation by sectors in 2009-2017, thousands

Agriculture, forestry and fishing

Manufacturing and extraction, energy and environment

Manufacturing of engineering goods

Building industry

Trade

Transport

Hotel \& restaurant

Information \& communication

Financial services, company services

Public administration, etc.

Education

Care

Personal and cultural services

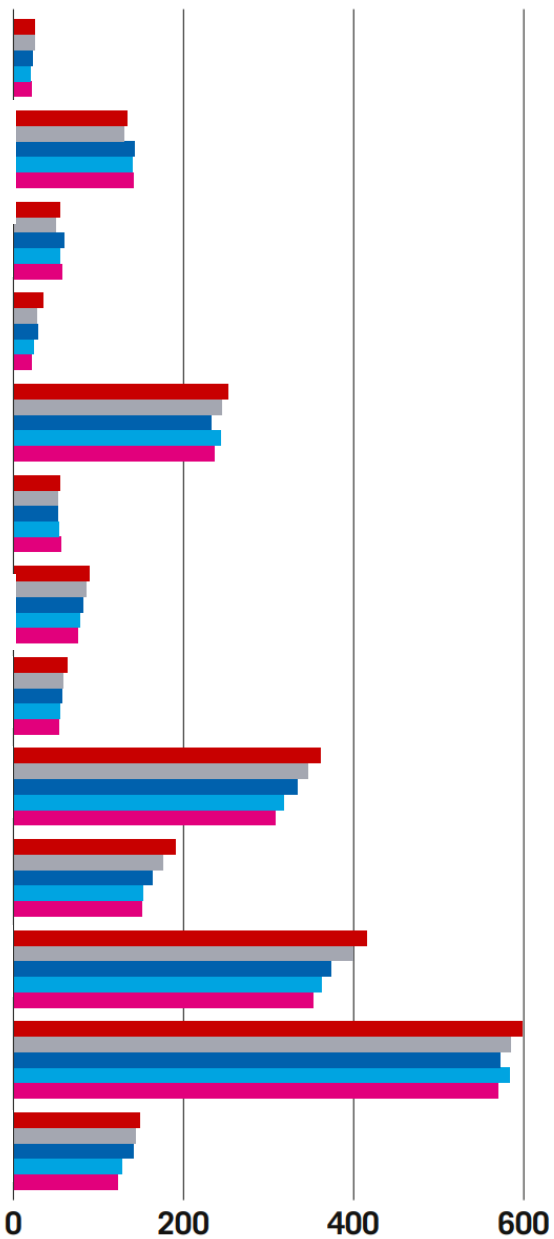

Source: SCB, AKU; Arbetsmiljöverket, 2018, p. 14. 
EXCLUSION AND INEQUALITY IN LATE WORKING LIFE

WORKING PAPER 5:

EXCLUSION AND INEQUALITY IN LATE WORKING LIFE: NATIONAL COUNTRY

CONTEXT - SWEDEN

Figure 26: Male (15-74) labour market participation by sectors in 2009-2017, thousands

Agriculture, forestry and fishing

Manufacturing and extraction, energy and environment

Manufacturing of engineering goods

Building industry

Trade

Transport

Hotel \& restaurant

Information \& communication

Financial services, company services

Public administration, etc.

Education

Care

Personal and cultural services
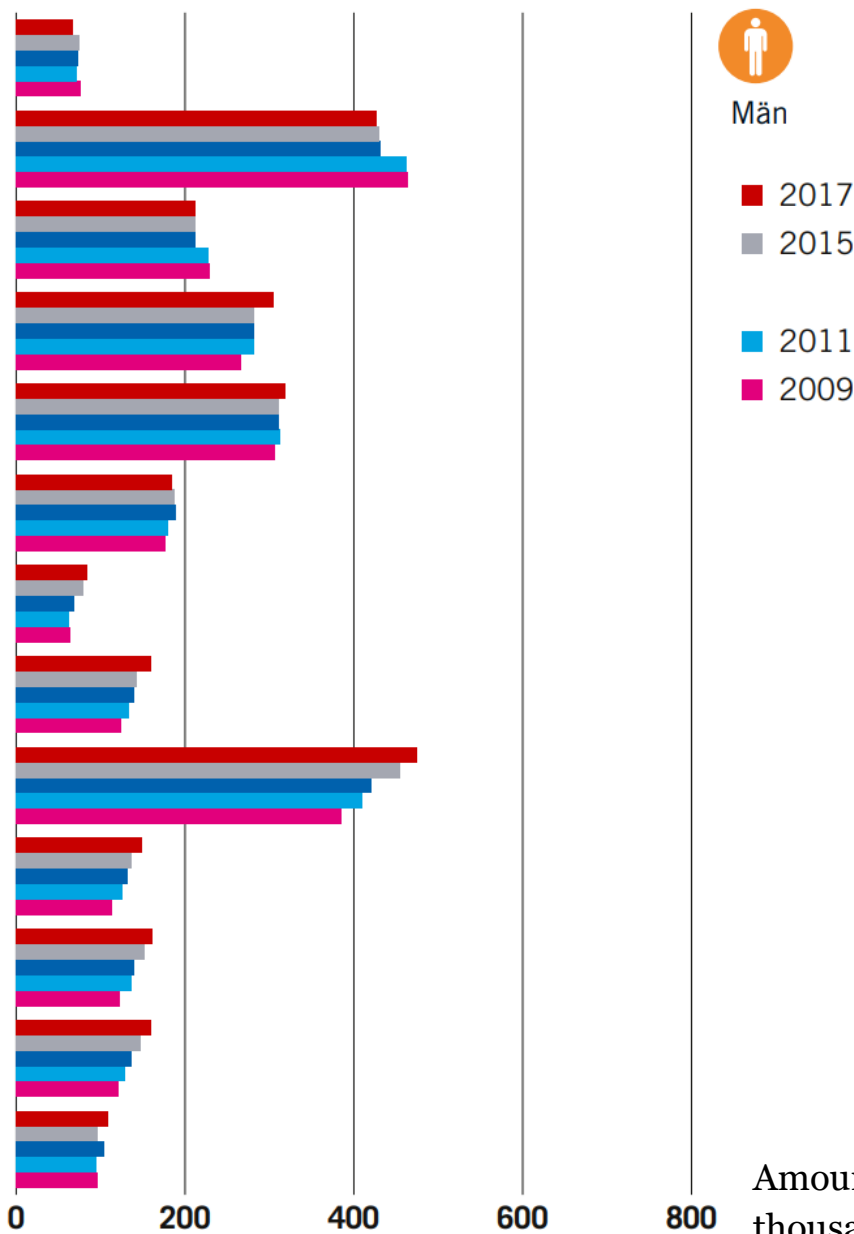

Amount (in 800 thousands)

Source: SCB, AKU; Arbetsmiljöverket, 2018, p. 15. 
EXCLUSION AND INEQUALITY IN LATE WORKING LIFE

WORKING PAPER 5:

EXCLUSION AND INEQUALITY IN LATE WORKING LIFE: NATIONAL COUNTRY

CONTEXT - SWEDEN

Figure 27: Amount of employed people in the population 16-64 years, by gender and type of employment, years 2009-2017

Self - employment \& assisting household member

Temporary employment

Permanent employment
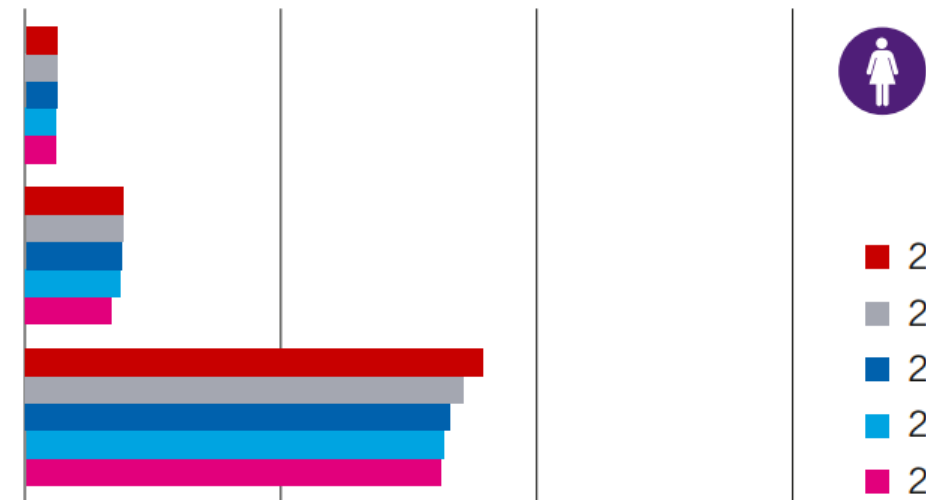

Employment in total

Self - employment \&
assisting household member

Temporary employment

Permanent employment

Employment in total

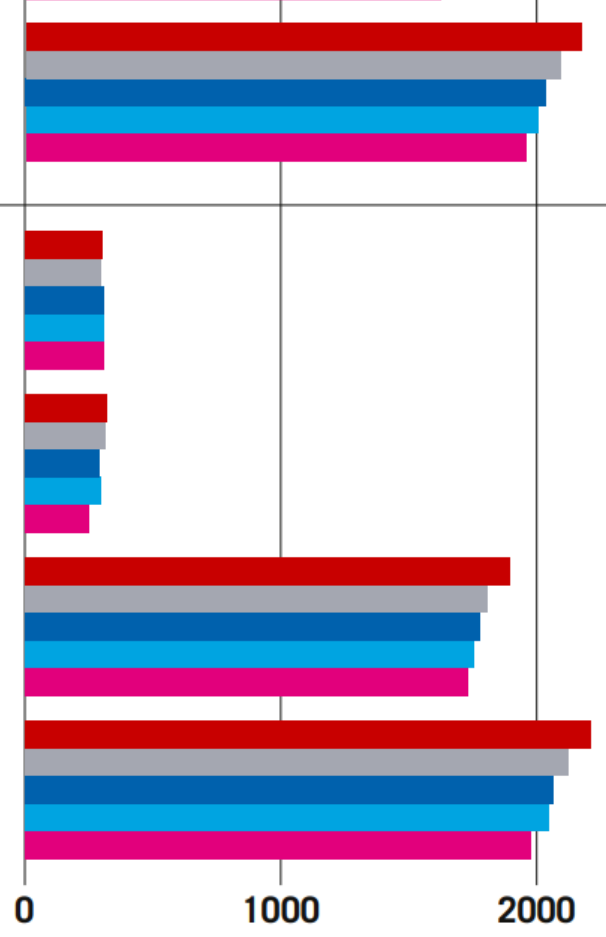

Self - employment \& .

?

1000

2000

Amount (in thousands)

Source: SCB, AKU; Arbetsmiljöverket, 2018, p. 16. 
EXCLUSION AND INEQUALITY IN LATE WORKING LIFE

WORKING PAPER 5:

EXCLUSION AND INEQUALITY IN LATE WORKING LIFE: NATIONAL COUNTRY CONTEXT - SWEDEN

Figure 28: Share of temporary employed by Swedish- or foreign-born and gender, 2005-2019

Percent of total employees

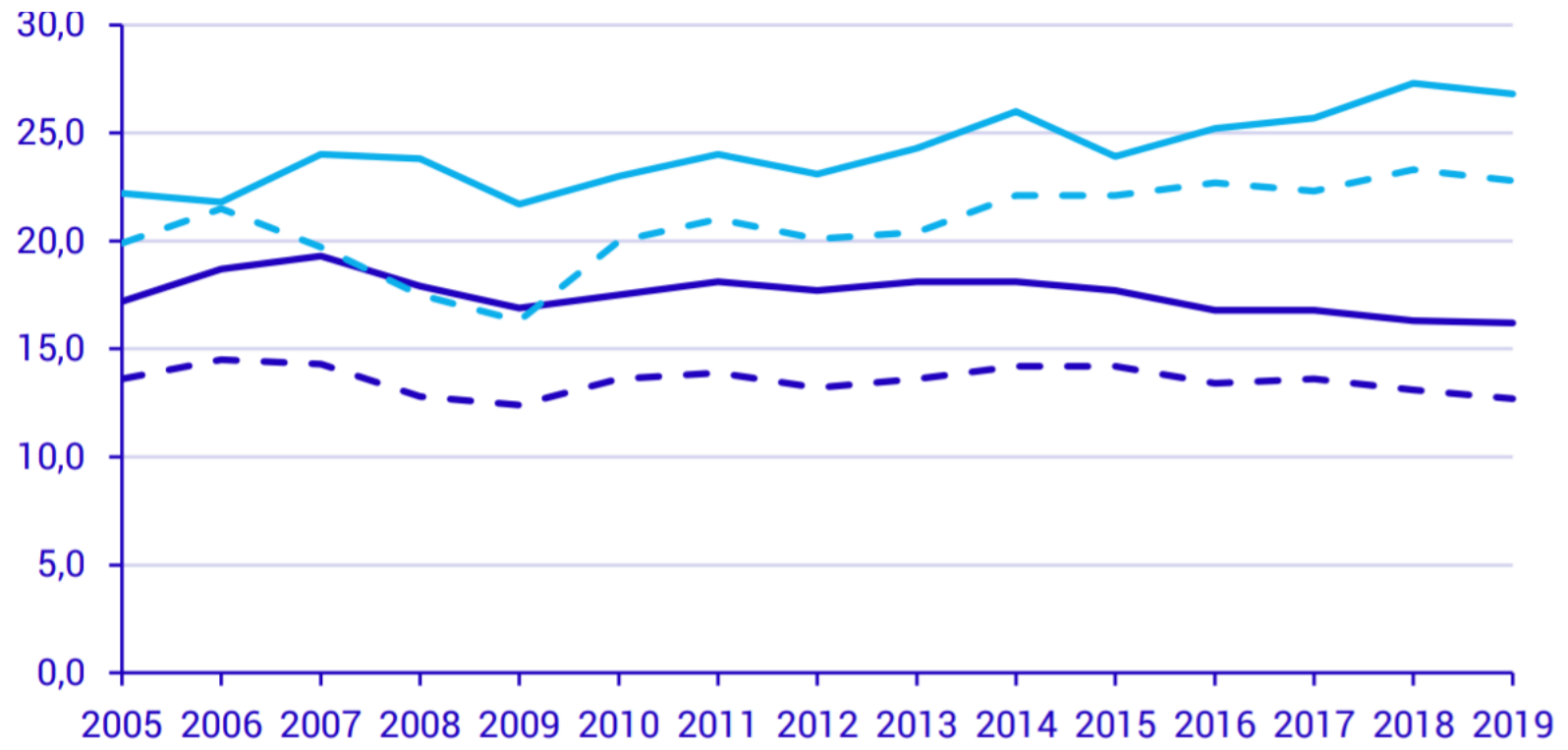

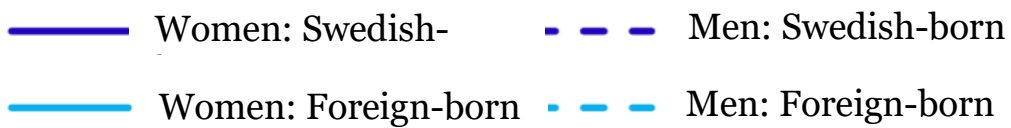

Source: AKU; SCB, 2020, p. 20. 